\title{
A taxonomic study of the genus Pseudostellaria in Korea
}

\section{Hyun JO and Muyeol KIM*}

\author{
Department of Biological Sciences, Chonbuk National University, Jeonju 54896, Korea
} (Received 4 March 2019; Revised 23 April 2019; Accepted 21 June 2019)

\begin{abstract}
The genus Pseudostellaria (Caryophyllaceae) in Korea was investigated in order to clarify the taxonomic positions and scientific names among the species in this genus based on morphological characteristics. $P$. $\times$ bohyeonsanensis and $P . \times$ seoraksanensis share several characteristics (trichome on the sepal margin and midvein, five petals, and stem reclining to the ground after flowering) with $P$. davidii. $P . \times$ bohyeonsanensis, resulting from natural hybridization of $P$. davidii and $P$. okamotoi var. longipedicellata, has sterile fruit and a long pedicel $(2.2-6.0 \mathrm{~cm}) . P . \times$ seoraksanensis, a natural hybrid of $P$. davidii and $P$. palibiniana var. palibiniana, has sterile fruit and a short pedicel $(1.1-1.8 \mathrm{~cm})$. . okamotoi var. longipedicellata shares several characteristics (long pedicels of chasmogamic flowers that elongate to the ground when bearing fruit and cleistogamic flowers with a long pedicel) with the related taxa P. okamotoi var. okamotoi. P. okamotoi var. longipedicellata has slender root tubers, glabrous pedicels, and 5-9 petals. P. palibiniana var. gageodoensis is described from Gageodo Island. It is similar to P. palibiniana var. palibiniana having chasmogamic flowers at the stem terminal, 5-7 petals, and a short pedicel, but $P$. palibiniana var. gageodoensis is distinguished by 1-2 rows of trichomes on the pedicel, a large sepal size, a large petal size, and a branched stem at its base. $P . \times$ biseulsanensis, from a natural hybrid of $P$. heterophylla and $P$. okamotoi var. longipedicellata, has a solitary aerial stem, a chasmogamic flower at the stem terminal, a shallow marginate or bitten petal apex, one row of trichomes on the pedicel, and sterile fruit. $P . \times$ segeolsanensis, from a natural hybrid of P. palibiniana var. palibiniana and P. okamotoi var. okamotoi, is described from Segeolsan Mt. It has numerous aerial stems, a chasmogamic flower at the stem terminal, 1-2 rows of trichomes on the pedicel, and fertile fruit. Consequently, the genus Pseudostellaria in Korea has been classified into eight species, four hybrids, two varieties, and five forms.
\end{abstract}

Keywords: Pseudostellaria, taxonomy, Caryophyllaceae, new taxa

개별꽃속(Pseudostellaria Pax)은 석죽과(Caryophyllaceae) 에 속하며, 세계적으로 18 분류군이 분포하고 $(\mathrm{Lu}$ and Rabeler, 2001), 한국에는 9 분류군이 분포하는 것으로 알 려져 있다(Jo et al., 2014; Kim, 2017).

개별꽃속은 다년생 초본으로 근경은 비후되었으며, 폐 쇄화가 달리는 특징이 있고(Choi, 2007), 종자 표면의 돌기 는 분류군에 따라 갈고리 모양으로 남아 있거나 유두상의 형태로 탈락하여 구릉상 기둥형을 이루어 근연속과 구별 되어 진다(Mizushima, 1965; Choi, 1999; Song et al., 2015).

Chung et al. (1937)은 덩굴미치광이(Krascheninnikovia davidii), 미치광이풀(K. heterophylla), 수염뿌리미치광이 (K. palibiniana), 가는잎미치광이(K. sylvatica) 등 4분류군 을 소개하였다. Ohwi (1937)는 일본, 한국, 만주, 중국 등에
분포하는 개별꽃속 16 분류군(13종 3 변종)에 대해 분류학 적 재검토를 하였으며, 이 중 지리산개별꽃(Pseudostellaria okamotoi), 숲개별꽃(P. setulosa), P. heterophylla var puberula 등 3 분류군은 기준채집지가 한반도인 분류군이다. 종자 표면의 돌기가 남아 있는지 없어지는지 여부에 따라 series Glochidiata와 series Mamillatae로 구별하였고, series Mamillatae는 상부 잎의 배열 방식에 따라 subseries Verticillatae와 subseries Distantes로 구분하였으며, 산개별 꽃(P. monantha)을 큰개별꽃(P. palibiniana $)$ 의 이명으로 처 리하고, 참개별꽃(P. coreana)을 개별꽃의 이명으로 처리 하였으며, 덩이뿌리개별꽃 (P. bulbosa)을 덩굴개별꽃의 이 명으로 처리하였다.

Mizushima (1965)는 일본에 자생하는 개별꽃속 5개 분

\footnotetext{
*Author for correspondence: mykim@jbnu.ac.kr
} 
류군에 대해 정리하였으며, Ohwi (1937)의 견해에 따라 종 자 표면의 돌기와 상부 잎의 배열방식을 중요하게 보았다. 또한 경남 함양에서 채집되어 Ohwi (1937)에 의해 신변종 기재된 P. heterophylla var. puberula를 품종(P. heterophylla f. puberula)으로 격하시켰다. Choi (1999)는 한반도 자생종으로 큰개별꽃, 지리산개별꽃, 숲개별꽃, 개별꽃(P. heterophylla), 덩굴개별꽃 $(P$. davidii), 가는잎개별꽃(P. sylvatica), 보현산 개별꽃 $(P$. davidii $\times$ palibiniana $)$, 비슬산개별꽃 $(P$. heterophylla $\times$ palibiniana)을 언급하였으며, 이들 분류군에 대한 수리분 류학적, 계통학적 유연관계를 제시하였다. 반면 대관령에 자생하는 것으로 알려진 긴개별꽃(P. japonica)은 숲개별 꽃의 오동정으로 보아 한반도 자생종에 포함시키지 않았 고, 태백개별꽃은 소화경의 길이를 제외하고는 큰개별꽃 과 유사하며, 큰개별꽃의 소화경 길이는 지리적 분포와 연관된 것으로 판단하였다. Choi (2007)는 한반도 자생종 으로 교잡종과 긴개별꽃을 제외한 6 분류군을 제시하였다.

Lee et al. (2012)은 태백개별꽃(P. longipedicellata)를 발표 하였으며, 소화경의 길이와 소화경이 줄기 기부로 처지는 특징을 주요 형질로 제시하였다. Jo et al. (2014)은 백두산 에 자생하는 애기개별꽃(P. baekdusanensis)을 발표하였으 며, Kim et al. (2015)는 애기개별꽃이 용늪에도 분포하며, 폐쇄화가 형성된다는 차이점을 보고하였다. Kim (2017)은 한반도 자생종으로 큰개별꽃, 지리산개별꽃, 숲개별꽃, 개별꽃, 덩굴개별꽃, 가는잎개별꽃, 긴개별꽃, 태백개별 꽃(P. okamotoi var. longipedicellata), 애기개별꽃 등 9분류 군을 정리하였다.

이와 같이 학자들에 따라 한반도 분포종에 대한 인식의 차이와 교잡종의 분류학적 처리 및 학명의 적용에 있어서 의 문제, Ohwi (1937)와 Mizushima (1965)에 의해 이명 처 리된 분류군을 특산식물로 인식하는 문제 등의 혼란이 있 어(Lee, 2013), 한국에 자생하는 개별꽃속 식물 8종 4교잡 종 2 변종 5 품종에 대해 외부 형태학적 형질을 바탕으로 새로운 종 검색표를 작성하고 분류군의 한계와 국명과 학 명을 명확히 하고자 본 연구를 수행하였다.

\section{재료 및 방법}

\section{재료}

본 연구에 사용된 재료는 2014년 4월부터 2018년 8월까 지 자생지에서 채집한 생체와 국립수목원 산림생물표본 관 $(\mathrm{KH})$ 에 소장된 표본을 사용하였다. 본 연구 기간 중 직 접 채집한 개체는 Lee (1985), Lee (1996a), Lee (1998), Choi (1999), Kim (2017)등의 문헌을 이용하여 동정하였고, 석 엽 표본으로 제작하여 전북대학교 생물학과 표본관(JNU) 에 보관하였으며, 일부는 묘포장에 이식하여 생육과정을 관찰하였다. 측정에 사용한 표본 목록은 Appendix 1에 수 록하였다.

\section{방법}

형태학적 정량형질은 전자식 버니어캘리퍼스(CD15CPX; Mitutoyo, Kawasaki, Japan)와 해부현미경(SM-10; Nikon, Tokyo, Japan)으로 측정하였고, 사진 촬영은 Nikon D800 DSLR 카메라에 $105 \mathrm{~mm}$ 접사 렌즈와 $20 \mathrm{~mm}$ 광각 렌 즈를 사용하였으며, 사진 촬영시 배경지와 $1 \mathrm{~mm}$ 눈금으 로 그려진 방안지를 활용하였다. 성숙한 개체를 대상으로 측정하였으나, 개화가 진행됨에 따라 또는 결실시기를 지 남에 따라 상태가 변하는 소화경의 길이, 상부 잎의 길이 와 너비, 폐쇄화 수, 괴경의 크기와 형태 등은 결실기를 기 준으로 관찰 및 측정하였으며, 개화 후기에는 거의 없어 지는 하부 잎은 개화 초기를 대상으로 측정하였다. 잎에 관련된 형질은 잎이 위윤생하는 분류군을 기준으로 소화 경에 인접한 4 개의 잎을 상부 잎으로 하였고, 줄기 가장 아 래쪽 잎(대체로 주걱형)을 하부 잎으로 하였으며, 상부 잎 과 하부 잎 사이의 잎을 중부 잎으로 하여 각각 측정하였 다. 정성형질 22 개와 정량형질 29 개를 관찰하여 Tables 1,2 에 정리하였고, 측정 기준은 모식도로 제시하였다(Fig. 1).

\section{결 과}

\section{형태학적 연구}

1. 괴경과 지하경

1) 괴경의 형태와 지하경

한국산 개별꽃속 식물은 다년생초본으로, 괴경을 가지 고 있다. 태백개별꽃과 비슬개별꽃(Pseudostellaria $\times$ biseulsanensis)은 가는 방추형(Fig. 2A)으로 나타났고, 큰개 별꽃은 가는 방추형(Fig. 2A)과 방추형(Fig. 2B)으로 나타 났다. 큰개별꽃은 가느다란 형태의 괴경이 특징이나 거제, 부산, 제주 개체는 짧고 굵은 형태의 방추형 개체가 널리 관찰되었다. 지리산개별꽃, 가거개별꽃(P. palibiniana var. gageodoensis $)$, 보현개별꽃 $(P . \times$ bohyeonsanensis $)$, 정영개별 꽃 $(P . \times$ segeolsanensis $)$ 은 방추형(Fig. 2B)으로 나타났으며, 긴개별꽃, 애기개별꽃, 덩굴개별꽃, 설악개별꽃 $(P \times$ seoraksanensis)은 방추형(Fig. 2B)과 순무형(Fig. 2C)으로 타나났다. 가는잎개별꽃은 순무형(Fig. 2C)으로 나타났다. 숲개별꽃은 지하경(Fig. 2D)이 있고, 지하경 중간에서 구 형, 타원형, 곤봉형 등의 괴경이 나타났다.

\section{2) 괴경의 수}

개화기와 폐쇄화 결실시기에 따라 그 수에 차이가 있음 을 관찰하였다. 개별꽃은 개화기 혹은 개화기 이전에는 대체로 1 개이고 드물게 2 개가 관찰되었으나, 폐쇄화 결실 기에는 대체로 2 개, 많게는 4 개까지 관찰되어, 다른 분류 군과의 식별 형질로 유용하지 못한 것으로 나타났다. 괴 경의 수가 가장 많은 분류군은 태백개별꽃으로 3 (13.6) 56 개, 큰개별꽃은 2 (13.1) 56개이고, 가장 적은 분류군은 애 기개별꽃으로 1 (1.2) 2개로 나타났다(Table 2). 


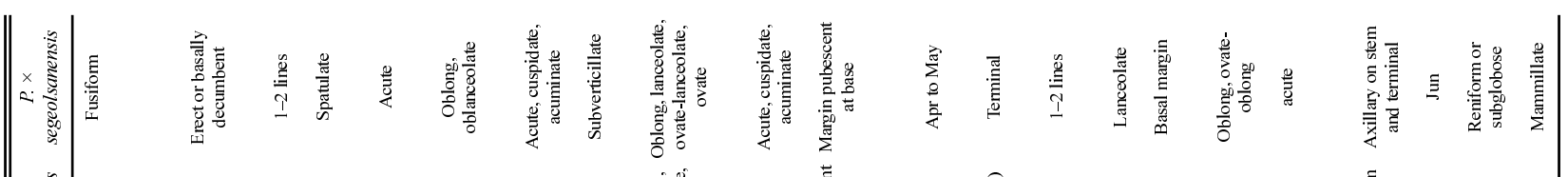

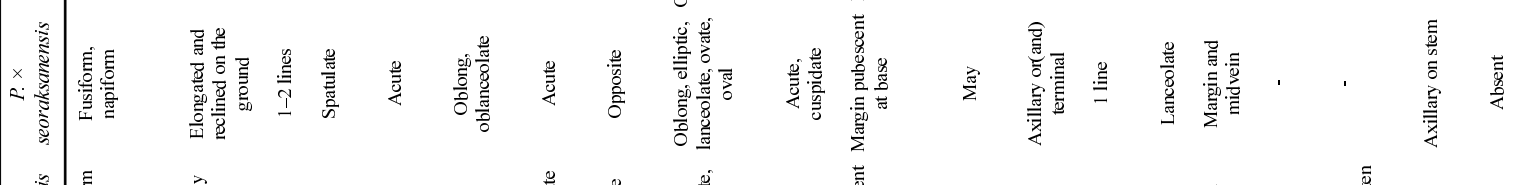

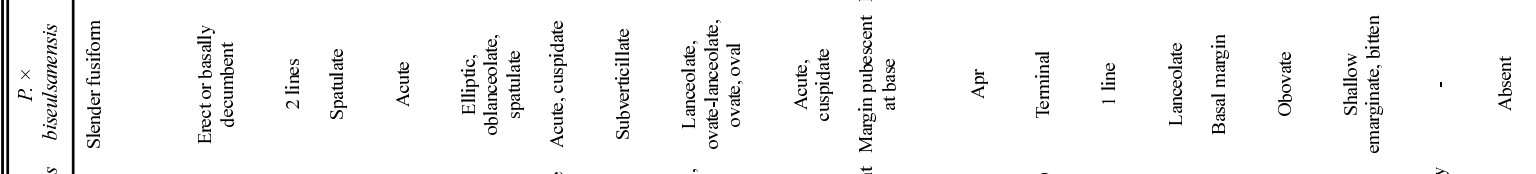
H II

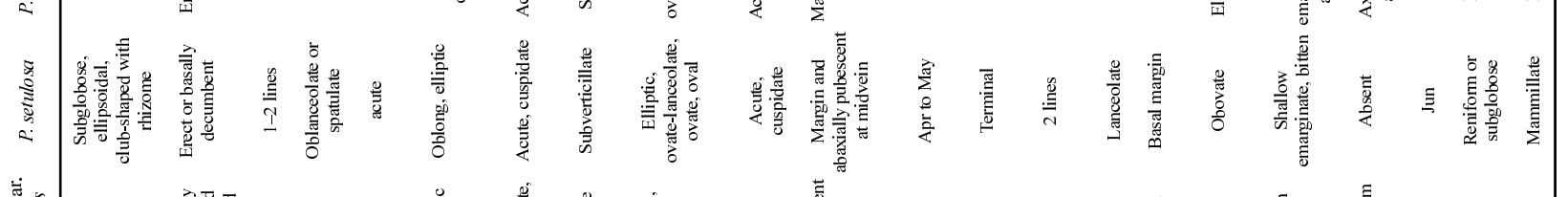

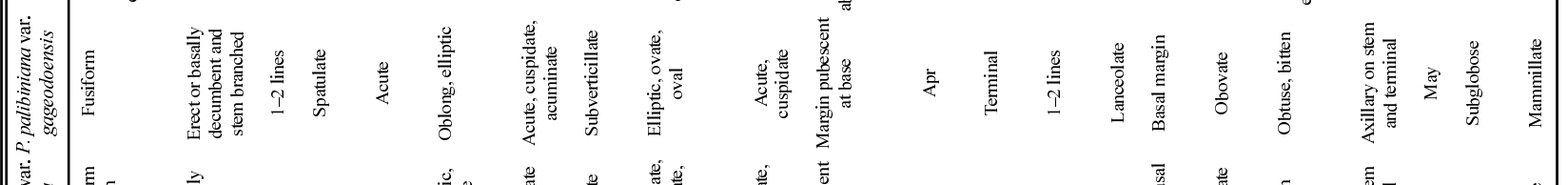

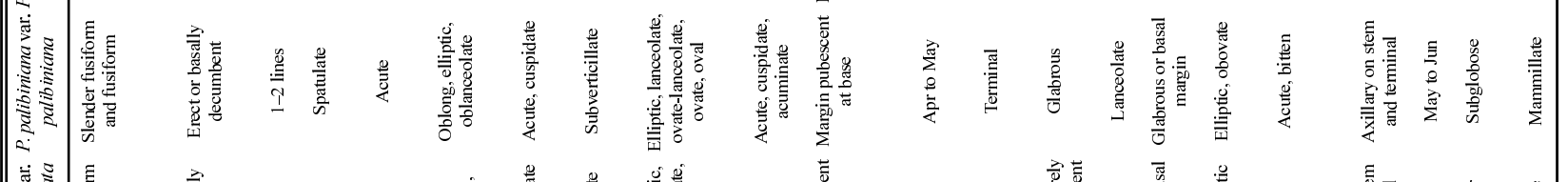
II

ل1 Wh! II In

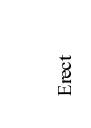

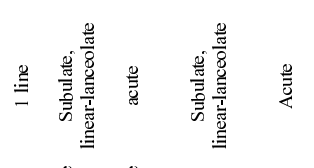




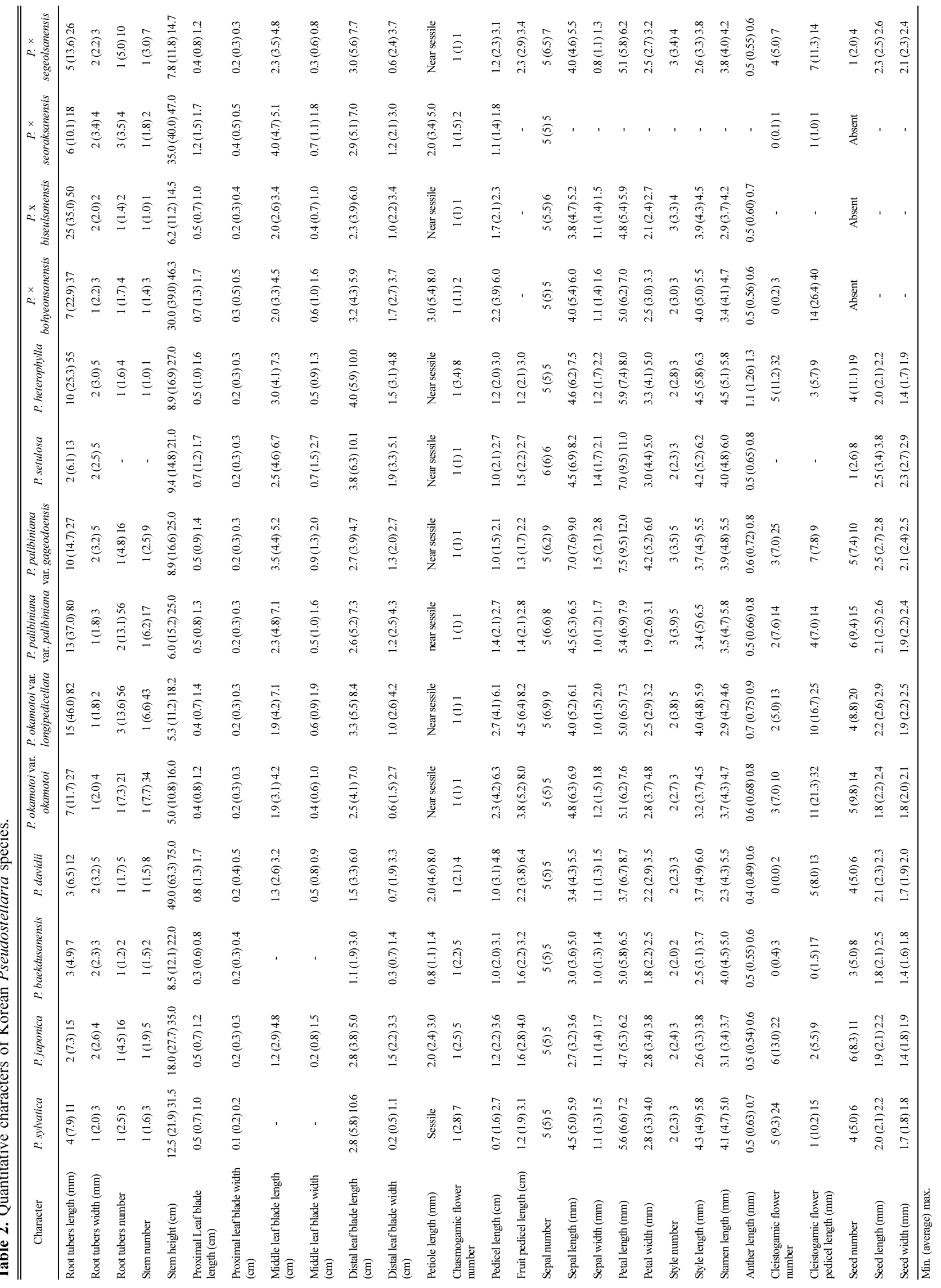



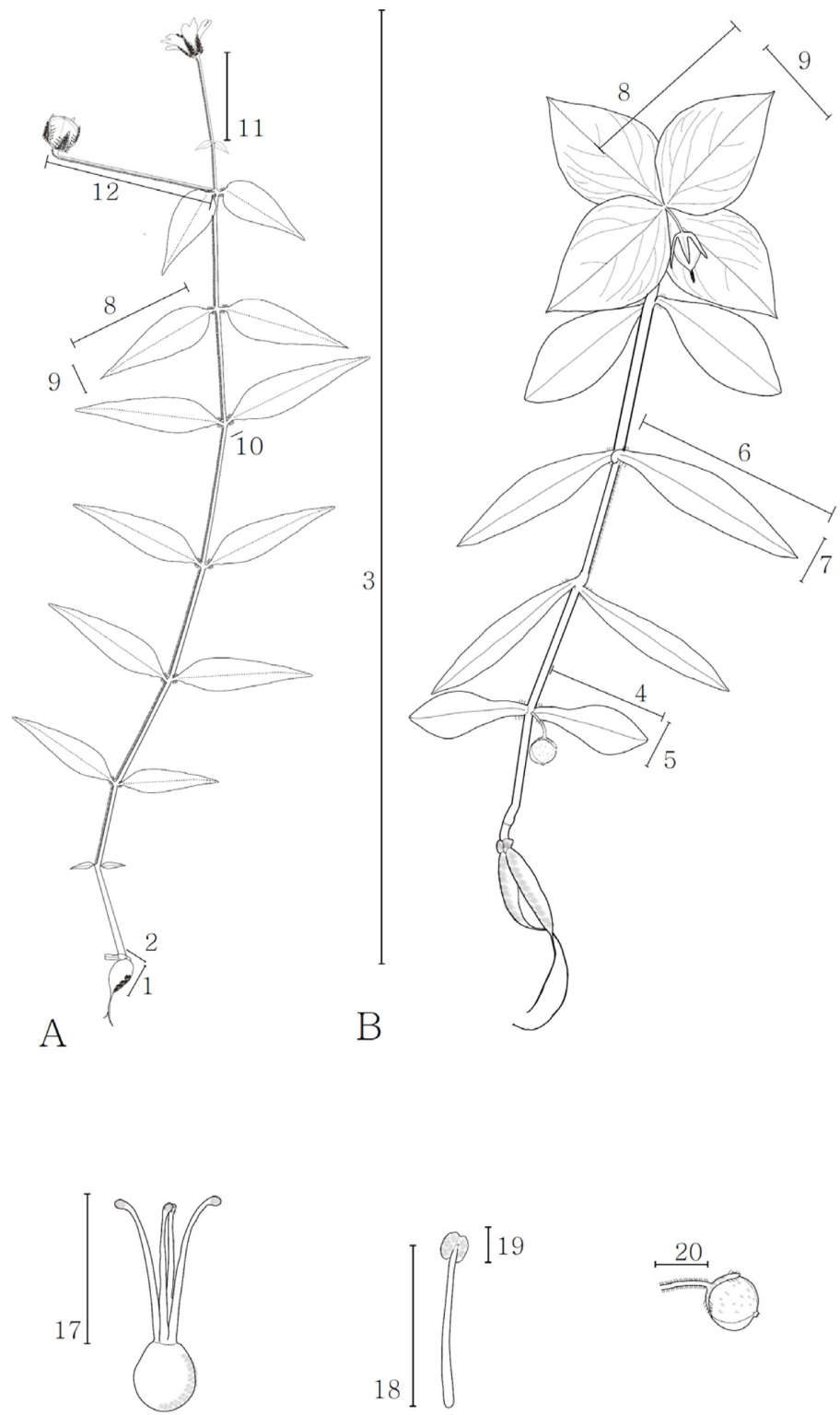

$\mathrm{H}$

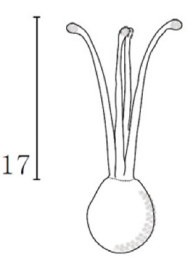

G
C
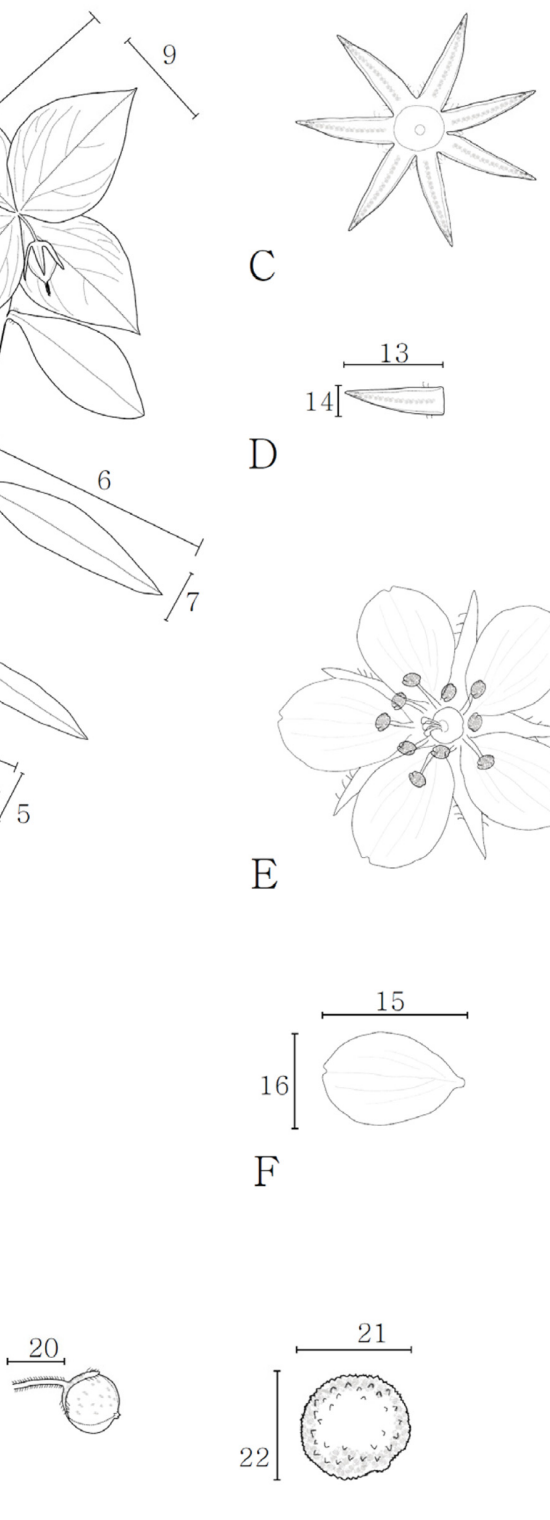

I
E
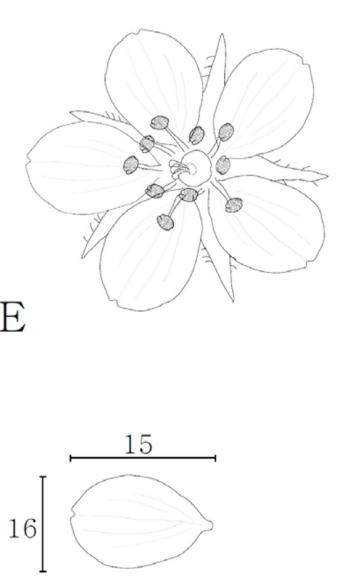

F

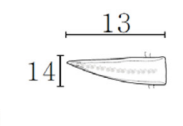

D

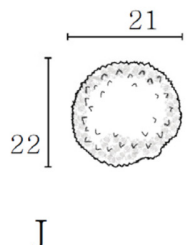

Fig. 1. Diagram of morphological characters of Korean Pseudostellaria species measured for morphological study. A. Distal leaves opposite. B. Distal leaves subverticillate. C. Sepals. D. Sepal. E. Chasmogamic flower. F. Petal. G. Pistil. H. Stamen; I. Cleistogamic flower. J. Seed. 1, root tuber length; 2 , root tuber width; 3 , stem height; 4, proximal leaf blade length; 5, proximal leaf blade width; 6 , middle leaf blade length; 7 , middle leaf blade width; 8 , distal leaf blade length; 9 , distal leaf blade width; 10, petiole length; 11, chasmogamic flower pedicel length; 12 , fruit pedicel length; 13, sepal length; 14, sepal width; 15, petal length; 16, petal width; 17, style length; 18, stamen length; 19, anther length; 20, cleistogamic flower pedicel length; 21, seed length; 22, seed width.

\section{3) 근경과 연결된 지상부 개체수}

단독으로 생육하는 분류군과 군생하는 분류군의 줄기 수를 파악하기 위해 관찰하였다. 태백개별꽃은 1 (6.6) 43 개로 가장 많았으며, 지리산개별꽃이 1 (7.7) 34개, 큰개별 꽃 1 (6.2) 17 개 순으로 많은 것으로 나타났다. 개별꽃과 비 슬개별꽃은 1 개로 가장 적은 것으로 나타났다(Table 2).

\section{2. 개화 후 줄기 형태}

가는잎개별꽃, 애기개별꽃, 지리산개별꽃, 태백개별꽃, 큰개별꽃, 가거개별꽃, 숲개별꽃, 비슬개별꽃, 정영개별 꽃은 직립하거나 기부에서 비스듬히 자라 직립하며, 개화 기와 결실기 모두 직립한다(Fig. 2E). 덩굴개별꽃, 보현개 별꽃, 설악개별꽃은 개화 초기에는 직립하나 시기가 지남 
에 따라 엽액에서 새로운 줄기가 분지되면서 땅위를 포복 하여 자라는 것으로 관찰되었다(Fig. $2 \mathrm{~F}$ ).

\section{3. 잎}

\section{1) 상부 잎 배열}

가는잎개별꽃, 애기개별꽃, 덩굴개별꽃, 보현개별꽃, 설 악개별꽃에서 대생으로 나타났으며(Fig. 1A), 지리산개별꽃, 태백개별꽃, 큰개별꽃, 가거개별꽃, 숲개별꽃, 개별꽃, 비슬 개별꽃, 정영개별꽃에서 위윤생으로 나타났다(Fig. 1B).

\section{2) 상부 엽신의 털}

가는잎개별꽃, 애기개별꽃, 덩굴개별꽃, 지리산개별꽃, 태백개별꽃, 큰개별꽃, 가거개별꽃, 개별꽃, 보현개별꽃, 비슬개별꽃, 설악개별꽃, 정영개별꽃은 엽신 가장자리 기 부에서만 나타났고(Fig. 2G), 솦개별꽃은 엽신 가장자리 와 잎 이면 중륵에서 나타났으며(Fig. $2 \mathrm{H}$ ), 긴개별꽃, 대관 령개별꽃, 영선큰개별꽃은 엽신 표면, 엽신 기부와 잎 이 면 중륵에서 나타났다(Fig. 2I).

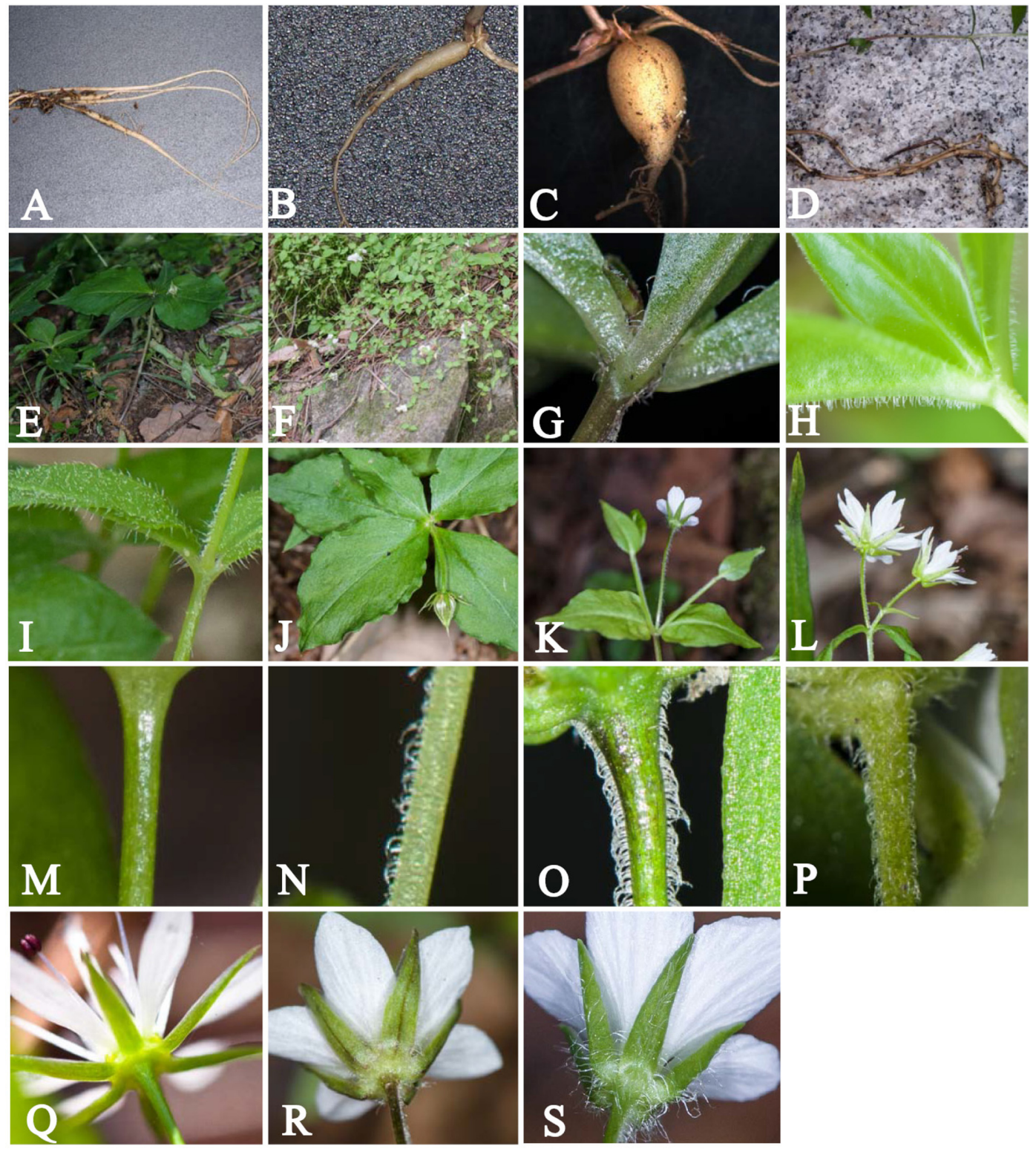

Fig. 2. Key characters of Korean Pseudostellaria species. A. Slender fusiform. B. Fusiform. C. Napiform. D. Rhizome and root tuber. E. Erect. F. Reclined on the ground. G. Margin pubescent at base. H. Margin and abaxially pubescent at midvein. I. Upper surface, margin, and abaxially pubescent at midvein. J. Terminal. K. Axillary. L. Axillary and terminal. M. Glabrous or rarely basally pubescent. N. 1 line. O. 2 line. P. Pubescent. Q. Glabrous. R. Basal margin. S. Margin and midvein. 


\section{4. 꽃}

1) 개방화가 달리는 위치

지리산개별꽃, 태백개별꽃, 큰개별꽃, 가거개별꽃, 숲 개별꽃, 개별꽃, 비슬개별꽃, 정영개별꽃은 정단부로 나 타났다(Fig. 2J). 덩굴개별꽃은 엽액에서만 나타났다(Fig. $2 \mathrm{~K})$. 가는잎개별꽃, 긴개별꽃, 애기개별꽃은 엽액과 정단 에서 나타났다(Fig. 2L). 보현개별꽃, 설악개별꽃은 엽액 또는 정단 또는 엽액과 정단에서 나타났다(Fig. 2J-L).

\section{2) 개방화 수}

상부 잎이 위윤생하는 분류군 중 지리산개별꽃, 태백개 별꽃, 큰개별꽃, 가거개별꽃, 숲개별꽃, 개별꽃, 비슬개별 꽃, 정영개별꽃은 정단부에서만 한개만 피었고, 개별꽃은 1(3.4)8개로 가장 많은 개방화가 피었다(Table 2).

\section{3) 개화기 결실기 소화경 길이}

개별꽃속 식물의 개방화 소화경의 길이는 개화 직전부 터 개화 후기 또는 결실기에 이르는 기간 동안 길어지는 것으로 관찰되었다. 결실되지 않는 보현개별꽃, 비슬개별 꽃, 설악개별꽃의 결실기 소화경 길이는 측정 항목에서 제외하였다. 지리산개별꽃 개화기 소화경은 2.3 (4.2) 6.3 $\mathrm{cm}$ 이고 결실기 소화경은 $3.8(5.2) 8.0 \mathrm{~cm}$, 태백개별꽃 개화 기 소화경은 2.7 (4.1) $6.1 \mathrm{~cm}$ 이고 결실기 소화경은 4.5 (6.4) $8.2 \mathrm{~cm}$ 로, 두 분류군이 비슷한 크기이고 개화기와 결실기 에 차이가 큰 것으로 관찰되었다. 큰개별꽃 개화기 소화 경은 1.4 (2.1) $2.7 \mathrm{~cm}$ 이고 결실기 소화경은 1.4 (2.1) $2.8 \mathrm{~cm}$ 로, 개화기와 결실기 차이가 거의 없는 것으로 관찰되었 다. 교잡종 중 보현개별꽃 개화기 소화경은 2.2 (3.9) $6.0 \mathrm{~cm}$ 로 태백개별꽃에 가까운 특징을 보였으며, 설악개별꽃 개 화기 소화경은 1.1 (1.4) $1.8 \mathrm{~cm}$ 로 큰개별꽃에 가까운 특징 을 보였다. 정영개별꽃 개화기 소화경은 $1.2(2.3) 3.1 \mathrm{~cm}$ 이 고 결실기 소화경은 $2.3(2.9) 3.4 \mathrm{~cm}$ 로 지리산개별꽃과 큰 개별꽃의 중간 크기로 관찰되었다(Table 2).

\section{4) 소화경 털}

태백개별꽃, 큰개별꽃은 소화경에 털이 전혀 없거나 부 분적으로 나타났고(Fig. $2 \mathrm{M}$ ), 애기개별꽃, 덩굴개별꽃, 보 현개별꽃, 비슬개별꽃, 설악개별꽃은 소화경에 털이 1 줄 있는 것으로 나타났으며(Fig. $2 \mathrm{~N}$ ), 긴개별꽃, 숲개별꽃은 소화경에 털이 2줄 있는 것으로 나타났다(Fig. 2O). 가는잎 개별꽃, 지리산개별꽃, 가거개별꽃, 정영개별꽃은 소화경
에 털이 1-2줄 나타났고(Fig. 2N-O), 개별꽃은 소화경 전 체에 털이 있는 것으로 나타났다(Fig. 2P).

\section{5) 꽃받침 털}

꽃받침 털은 털이 없거나, 기부 가장자리, 가장자리와 중륵에 나타나는 등 다양하게 관찰되었다. 태백개별꽃, 큰개별꽃은 무모이거나 기부 가장자리에도 나타났고 (Fig. 2Q-R), 애기개별꽃, 지리산개별꽃, 가거개별꽃, 숲개 별꽃, 비슬개별꽃, 정영개별꽃은 기부 가장자리에만 나타 났다(Fig. 2R). 긴개별꽃, 덩굴개별꽃, 개별꽃, 보현개별꽃, 설악개별꽃은 가장자리와 중륵에 모두 나타나 다른 분류 군과 구별되었다(Fig. 2S).

\section{6) 꽃받침 수}

꽃받침 수는 5개, 6 개, 5-7(9)개로 다양하게 나타났다. 가는잎개별꽃, 긴개별꽃, 애기개별꽃, 덩굴개별꽃, 지리 산개별꽃, 개별꽃, 보현개별꽃, 설악개별꽃은 5 개로 나타 났으며, 숲개별꽃은 6개, 비슬개별꽃은 5-6개, 정영개별 꽃은 5-7개, 태백개별꽃과 가거개별꽃은 5-7(9)개, 큰개별 꽃은 5-7(8)개로 관찰되었다(Table 2).

\section{7) 꽃받침 길이와 너비}

꽃받침 길이는 가거개별꽃이 7.0 (7.6) $9.0 \mathrm{~mm}$ 로 가장 큰 것으로 나타났고, 긴개별꽃이 2.7 (3.2) $3.6 \mathrm{~mm}$ 로 가장 작은 것으로 나타났다. 꽃받침 너비는 가거개별꽃이 1.5 (2.1) $2.8 \mathrm{~mm}$ 로 가장 넓은 것으로 나타났고, 정영개별꽃 이 0.8 (1.1) $1.3 \mathrm{~mm}$ 로 가장 좁은 것으로 나타났다. 지리 산개별꽃(길이 4.8 [6.3] $6.9 \mathrm{~mm}$, 너비 1.2 [1.5] $1.8 \mathrm{~mm}$ ), 태백개별꽃(길이 4.0 [5.2] $6.1 \mathrm{~mm}$, 너비 1.0 [1.5] $2.0 \mathrm{~mm}$ ), 큰개별꽃(길이 4.5 [5.3] $6.5 \mathrm{~mm}$, 너비 1.0 [1.2] $1.7 \mathrm{~mm}$ )은 중첩되어 나타났으나, 가거개별꽃은 길이 7.0 (7.6) $9.0 \mathrm{~mm}$ 이고 너비 1.5 (2.1) $2.8 \mathrm{~mm}$ 로 다른 분류군과 뚜렷 하게 구별되었다.

\section{8) 꽃잎 길이와 너비}

가거개별꽃이 길이 7.5 (9.5) $12.0 \mathrm{~mm}$ 이고 너비 4.2 (5.2) $6.0 \mathrm{~mm}$ 로 전체 분류군 중 가장 커서 큰개별꽃(길이 5.4 [6.9] $7.9 \mathrm{~mm}$, 너비 1.9 [2.6] $3.1 \mathrm{~mm}$ )과 뚜렷하게 구별되었 다. 다른 분류군은 대체로 중첩되어 나타났으나(길이 3.7$8.0 \mathrm{~mm}$ ), 숲개별꽃은 길이 $7.0(9.5) 11.0 \mathrm{~mm}$ 로 가거개별꽃 과 비슷한 것으로 나타났다.

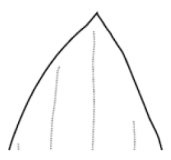

A

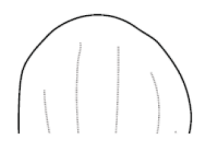

B

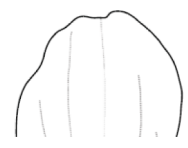

C

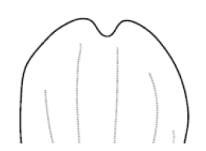

$\mathrm{D}$

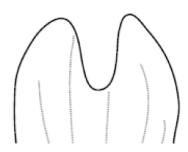

E

Fig. 3. Shape of petal apex of Korean Pseudostellaria species. A. Acute. B. Obtuse. C. Bitten. D. Shallow emarginate. E. Deep emarginate. 
9) 꽃잎 정단부 형태

꽃잎 정단부 형태는 예두, 둔두, 결각상, 얕은 요두, 깊은 요두로 나타났다. 태백개별꽃과 정영개별꽃은 예두(Fig. $3 \mathrm{~A}$ )만 나타났고, 큰개별꽃은 예두와 결각상(Fig. $3 \mathrm{~A}, \mathrm{C})$, 가거개별꽃은 둔두와 결각상 $(\mathrm{Fig} .3 \mathrm{~B}, \mathrm{C})$, 긴개별꽃과 보 현개별꽃은 얕은 요두(Fig. 3D), 숲개별꽃과 비슬개별꽃 은 결각상과 얕은 요두(Fig. $3 \mathrm{C}, \mathrm{D})$, 지리산개별꽃은 예두 와 둔두(Fig. $3 \mathrm{~A}, \mathrm{~B})$, 개별꽃은 예두, 둔두, 결각상, 얕은 요 두(Fig. 3A-D)로 가장 다양하게 나타났다. 가는잎개별꽃 과 애기개별꽃은 깊은 요두(Fig. $3 \mathrm{E}$ )로 다른 분류군과 뚜 렷하게 구별되었다.

\section{5. 폐쇄화 유무와 위치}

폐쇄화는 없거나 엽액, 줄기 정단부, 새로 분지된 줄기 에서 관찰되었다. 숲개별꽃은 폐쇄화가 없으며, 가는잎 개별꽃은 엽액에서 나타났고, 긴개별꽃, 지리산개별꽃, 태백개별꽃, 큰개별꽃, 가거개별꽃, 개별꽃, 정영개별꽃 은 엽액과 정단부에서 나타났다. 애기개별꽃은 백두산 개체는 폐쇄화가 관찰되지 않았으나 용늪에서 채집된 표본에서는 새로 분지된 줄기에서 폐쇄화가 관찰되었 다. 덩굴개별꽃은 폐쇄화가 하부 엽액에 달리지만 매우 낮은 빈도로 관찰되었으며, 덩굴개별꽃의 교잡종인 설 악개별꽃과 보현개별꽃은 폐쇄화가 존재하나 덩굴개별 꽃과 마찬가지로 관찰하기 어려운 것으로 나타났다 (Table 1).

\section{분류학적 기재}

개별꽃속 Pseudostellaria Pax, Nat. Pflanzenfam., ed. 2. 16c: $318,1934$.

Type species: P. rupestris (Turczaninow) Pax.

Krascheninikovia Turczaninow ex Fenzl in Endlicher, Gen. Pl. 13: 968, 1840, not Gueldenstaedt, Novi Comment. Acad. Sci. Imp. Petrop. 16: 551, 1772.

다년생 초본으로 근경은 비후되어 있다. 줄기는 직립 하거나 기부에서 굽어져서 직립하며, 결실기에 땅위를 포복하기도 한다. 하부, 중부 잎은 대생하나 상부 잎은 대생 또는 위윤생 한다. 개방화는 줄기 정단부 또는 엽액 에서 1-다수의 꽃이 핀다. 꽃받침과 꽃잎의 수는 같고, 5 개 또는 6개, 5-7(-9)개이고 꽃잎이 꽃받침 보다 길다. 꽃 잎 정단부는 예두, 결각상, 얕은 요두, 깊은 요두, 둔두이 다. 암술대는 2-5개, 수술은 꽃받침수의 2 배이다. 폐쇄화 는 엽액 또는 줄기 정단부에 달리며 꽃잎이 없고 축소된 수술이 흔히 2개 있다. 열매는 삭과이고, 종자는 신장형 또는 구형이다.

분포: 한국, 중국, 티벳, 부탄, 일본, 러시아, 몽골, 인도, 네 팔, 파키스탄, 미국, 유고슬라비아, 이탈리아, 오스트리아.

\section{한국산 개별꽃속의 검색표}

1. 상부 잎은 대생하며, 크기와 모양이 나머지 잎과 비슷하다.

2. 개화 후에도 직립한다.

3. 잎은 침형 또는 선상피침형이다. · 1. P. sylvatica

3. 잎은 피침형, 난상피침형, 난형이다.

4. 엽연과 잎이면 중륵에 털이 있다.

2. P. japonica

4. 잎 기부에만 털이 있다. .. 3. P. baekdusanensis 2. 개화 후에 덩굴성이 된다.

5. 원줄기의 잎과 엽액에서 분지된 줄기의 잎이 동형(난형)이며, 종자가 결실한다. … 4. P. davidii

5. 원줄기의 잎과 엽액에서 분지된 줄기의 잎이 이형이며, 종자가 결실되지 않는다.

6. 소화경이 $2 \mathrm{~cm}$ 이상이다.

9. P. $\times$ bohyeonsanensis

6. 소화경이 $2 \mathrm{~cm}$ 미만이다.

11. $P . \times$ seoraksanensis

1. 상부 잎은 위윤생하며, 나머지 잎에 비해 가장 크다.

7. 지하경이 있다.

7. P. setulosa

7. 지하경이 없다.

8. 소화경 전체에 털이 있다. 꽃은 (1)2-5(8)개 핀다. .... 8. P. heterophylla

8. 소화경에 털이 없거나 1-2줄 있다. 꽃은 한개 만 핀다.

9. 결실기 소화경은 $3.5 \mathrm{~cm}$ 이상이고, 결실기에 줄기 기부로 길어져 굽는다. … 5. P. okamotoi

9. 결실기 소화경은 $3.5 \mathrm{~cm}$ 미만이고, 결실기에 줄기 기부로 길어지지 않는다.

10. 종자가 결실되지 않는다. 지상부 줄기는 하나이고, 소화경에 털이 1줄이다

10. P. × biseulsanensis

10. 종자가 결실된다. 지상부 줄기는 1-17개 이고, 소화경에 털이 없거나 1-2줄이다.

11. 삭과의 종자수는 5 개 이상이다. 결실 기 소화경 길이는 $1.3-2.8 \mathrm{~cm}$ 이다. $\cdots \cdots . . .$.

6. P. palibiniana

11. 삭과의 종자수는 1-4개이다. 결실기 소화경 길이는 $2.3-3.4 \mathrm{~cm}$ 이다.

12. $P . \times$ segeolsanensis

1. Pseudostellaria sylvatica (Maxim.) Pax, Nat. Pflanzenfam., ed. 2. 16c: 318, 1934 (Fig. 4A)--TYPE: Russia. Khabarovsk Region, C. J. Maximowicz 21 May 1855 (holotype: LE); Krascheninikovia sylvatica Maxim., Prim. Fl. Amur. 57, 1859; Stellaria sylvatica (Maxim.) Maxim. ex. Regel, Bull. Soc. Imp. Naturalistes Moscou 35: 302, 1862.

국명: 가는잎개별꽃 Ga-neun-ip-gae-byeol-kkot. 
괴경은 순무형으로 1-5개가 달리며, 길이는 4-11 mm이 고, 너비는 1-3 mm이다. 지상부 줄기는 1-3개로 괴경을 통 해 이웃하여 연결되어 있다. 식물체의 높이는 $12.5-$ $31.5 \mathrm{~cm}$ 이고 직립하며, 줄기의 털은 1줄이다. 하부 잎은 침 형, 선상피침형이고, 엽선은 예두이고, 엽신 길이는 $0.5-$ $1.0 \mathrm{~cm}$ 이고 너비는 $0.1-0.2 \mathrm{~cm}$ 이다. 상부 잎은 대생하고, 침형, 선상피침형이며, 엽선은 예두이다. 엽신의 길이는 2.8-10.6 cm, 너비는 0.2-1.1 cm로 잎 기부에 털이 있다. 엽 병은 없다. 개화시기는 5-6 월이며, 꽃은 엽액과 정단부에 서 1-7개 핀다. 소화경은 털이 1-2줄의 있으며, 개화기 소 화경 길이는 $0.7-2.7 \mathrm{~cm}$ 이고, 결실기 소화경의 길이는 $1.2-$ $3.1 \mathrm{~cm}$ 이다. 꽃받침은 5 개이고, 피침형으로 길이는 4.5$5.9 \mathrm{~mm}$ 이고, 너비는 1.1-1.5 mm이며, 기부 가장자리에 털 이 있다. 꽃잎은 5장이고, 도란형으로 깊은 요두이며, 길 이는 5.6-7.2 mm, 너비는 2.8-4.0 mm이다. 암술대의 수는 2-3개이고, 길이는 4.3-5.8 mm이다. 수술의 수는 10 개이고, 길이는 4.1-5.0 mm이며, 약은 자갈색으로 길이는 0.5$0.7 \mathrm{~mm}$ 이다. 폐쇄화는 엽액에 5-24개 달리며, 폐쇄화 소 화경의 길이는 $1-15 \mathrm{~mm}$ 이다. 열매는 삭과이며 6-7월 결 실하며, 4-6개의 신장형 종자가 들어있다. 종자 표면에 유 두상 돌기가 있으며, 길이는 2.0-2.2 mm, 너비는 1.7$1.8 \mathrm{~mm}$ 이다.

국내분포: 강원(설악산), 함북(백두산, 관모봉, 칠보산), 평북(묘향산).

국외분포: 중국(만주), 부탄, 일본, 러시아.

생육지: 고지대 능선의 건조한 지형, 산지 숲속(백두산) 의 건조하거나 습한 지형.

분류학적 검토: 가는잎개별꽃은 잎은 대생이고 침형 또 는 선상피침형이며, 꽃잎은 5 장으로 깊은 요두인 점이 특 징이다.

2. Pseudostellaria japonica (Korsh.) Pax, Nat. Pflanzenfam., ed. 2. 16c: 318, 1934 (Fig. 4B).-TYPE: Japan. Nambu, Tschonoski s.n. (holotype: ?); Krascheninikovia japonica Korsh., Bull. Acad. Imp. Sci. Saint-Petersbourg, Ser. 5, 9: 40, 1898.

국명: 긴개별꽃 Gin-gae-byeol-kkot.

괴경은 방추형 또는 순무형으로 1-16개가 달리며, 길이 는 2-15 mm이고, 너비는 2-4 mm이다. 지상부 줄기는 1-5 개로 괴경을 통해 이웃하여 연결되어 있다. 식물체의 높 이는 18.0-35.0 cm이고 직립하거나 기부에서 굽어져 직립 하며, 줄기의 털은 1-2줄이다. 하부 잎은 주걱형이고, 엽선 은 예두이고, 엽신 길이는 $0.5-1.2 \mathrm{~cm}$ 이고 너비는 $0.2-$ $0.3 \mathrm{~cm}$ 이다. 중부 잎은 장타원형, 타원형, 도피침형이고, 엽선은 예두 또는 첨두이고, 엽신의 길이는 $1.2-4.8 \mathrm{~cm}$, 너 비는 0.2-1.5 cm이다. 상부 잎은 대생하고, 타원형, 난상피 침형, 난형이며, 엽선은 예두 또는 첨두이다. 엽신의 길이
는 2.8-5.0 cm, 너비는 1.5-3.3 cm로 잎 표면, 엽연과 잎 이 면 중륵에 털이 있다. 엽병은 2-3 mm이다. 개화기는 5월 이며, 꽃은 엽액과 정단부에서 1-5개 핀다. 소화경에는 2 줄의 털이 있으며, 개화기 소화경 길이는 $1.2-3.6 \mathrm{~cm}$ 이고, 결실기 소화경의 길이는 $1.6-4 \mathrm{~cm}$ 이다. 꽃받침은 5 개이고, 피침형으로 길이는 2.7-3.6 mm이고, 너비는 $1.1-1.7 \mathrm{~mm}$ 이 며, 가장자리와 중륵에 털이 있다. 꽃잎은 5장이고, 도란 형으로 얕은 요두이며, 길이는 4.7-6.2 mm, 너비는 2.8$3.8 \mathrm{~mm}$ 이다. 암술대의 수는 2-3개이고, 길이는 2.6-3.8 mm 이다. 수술의 수는 10 개이고, 길이는 3.1-3.7 mm이며, 약은 자갈색으로 길이는 $0.5-0.6 \mathrm{~mm}$ 이다. 폐쇄화는 엽액과 정 단부에 6-22개 달리며, 폐쇄화 소화경의 길이는 2-9 mm 이다. 열매는 삭과이며 6월 결실하며, 6-11개의 구형 종자 가 들어있다. 종자 표면에 유두상 돌기가 있으며, 길이는 1.9-2.2 mm, 너비는 1.4-1.9 mm이다.

국내분포: 강원(인제, 평창, 홍천, 횡성, 원주), 경북(영주, 봉화, 칠곡, 군위), 전북(무주), 함북(백두산).

국외분포: 중국, 일본, 러시아.

생육지: 계곡 주변의 약간 습하거나 습한 지형 또는 산 지 능선.

분류학적 검토: 긴개별꽃은 1966년 대관령에서 처음 발 견된 것으로 설명되어 있으나(Lee, 1985), 그동안 숲개별 꽃(P. setulosa)을 오동정한 것으로 인식되어 왔다. 긴개별 꽃은 잎 표면, 엽연과 잎 이면 중륵에 털이 있고 꽃잎 5장 이고 얕은 요두인 점이 특징이며, 주로 계곡 주변의 습한 지형에 생육한다. 단독으로 생육하기 보다는 대체로 여러 개체가 무리를 지어 군락을 형성한다. 잎이 대생하고 덩 굴성이 아니라는 점에서 애기개별꽃과 긴개별꽃은 외형 상 유사하나, 애기개별꽃은 잎 기부에만 털이 있고, 소화 경에 털이 1줄 있으며, 식물체가 작아서 $(8.5$ [12.1] $22 \mathrm{~cm})$ 쉽게 구별된다.

\section{Pseudostellaria baekdusanensis M. Kim, Korean J. Pl.}

Taxon. 44: 172, 2014 (Fig. 4C).-TYPE: Korea. Baekdusan Mt., M. Kim, 20140241 (holotype: JNU!).

국명: 애기개별꽃 Ae-gi-gae-byeol-kkot.

괴경은 방추형 또는 순무형으로 1-2개가 달리며, 길이 는 3-7 mm이고, 너비는 2-3 mm이다. 지상부 줄기는 1-2개 로 괴경을 통해 이웃하여 연결되어 있다. 식물체의 높이 는 8.5-22.0 cm이고 직립하며, 줄기의 털은 1줄이다. 하부 잎은 타원형이고, 엽선은 예두이고, 엽신 길이는 0.3$0.8 \mathrm{~cm}$ 이고 너비는 $0.2-0.4 \mathrm{~cm}$ 이다. 상부 잎은 대생하고, 피침형 또는 난상피침형이며, 엽선은 예두이다. 엽신의 길이는 1.1-3.0 cm, 너비는 0.3-1.4 cm로 잎 기부에 털이 있 다. 엽병은 0.8-1.4 mm이다. 개화기는 5-6월이며, 꽃은 엽 액과 정단부에서 $1-5$ 개 핀다. 소화경에는 1 줄의 털이 있 으며, 개화기 소화경 길이는 $1.0-3.1 \mathrm{~cm}$ 이고, 결실기 소화 

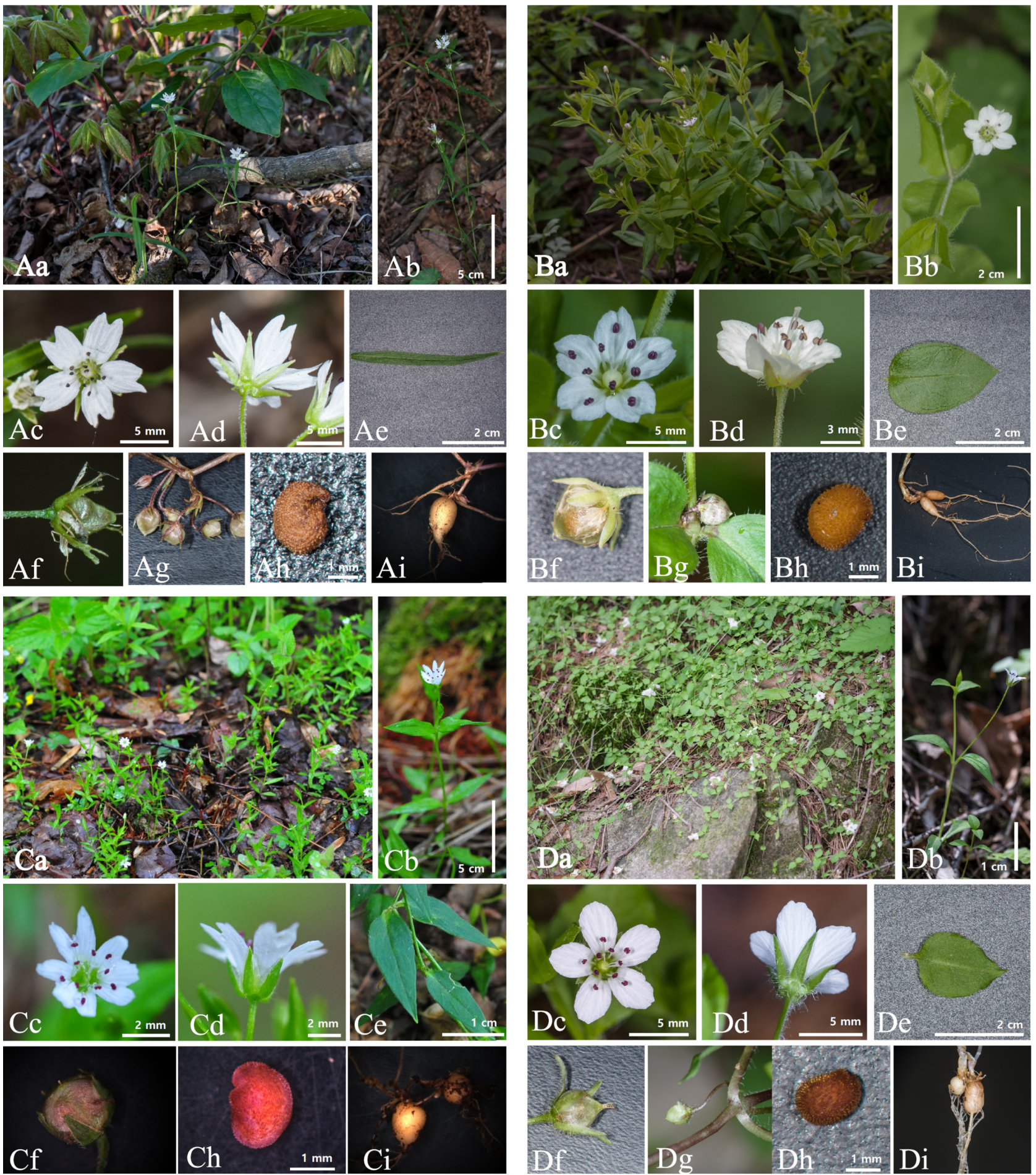

Fig. 4. Photographs of 4 Pseudostellaria species in Korea. A. P. sylvatica. B. P. japonica. C. P. baekdusanensis. D. P. davidii. a. Habit. b. Inflorescence. c. Chasmogamic flower. d. Sepal \& pedicel. e. Distal leaf. f. Capsule. g. Cleistogamic flower. h. Seed. i. Tuber root.

경의 길이는 $1.6-3.2 \mathrm{~cm}$ 이다. 꽃받침은 5 개이고, 피침형으 로 길이는 3-5 mm이고, 너비는 $1.0-1.4 \mathrm{~mm}$ 이며, 기부 가장 자리에 털이 있다. 꽃잎은 5장이고, 도란형으로 깊은 요두
이며, 길이는 $5.0-6.5 \mathrm{~mm}$, 너비는 $1.8-2.5 \mathrm{~mm}$ 이다. 암술대 의 수는 2 개이고, 길이는 2.5-3.7 mm이다. 수술의 수는 10 개이고, 길이는 4.0-5.0 mm이며, 약은 자갈색으로 길이는 
0.5-0.6 mm이다. 폐쇄화는 없거나 엽액에서 분지된 가지 에 0-3개 달리며, 폐쇄화 소화경의 길이는 0-17 mm이다. 열매는 삭과이며 6월 결실하며, 3-8개의 신장형 종자가 들어있다. 종자 표면에 유두상 돌기가 있으며, 길이는 1.8$2.5 \mathrm{~mm}$, 너비는 1.4-1.8 mm이다.

국내분포: 함북(백두산), 강원(인제-용늪).

생육지: 습한 지형.

분류학적 검토: 애기개별꽃은 식물체가 작고 꽃잎은 5 장이고 깊은 요두이며, 엽액과 정단부에서 꽃이 피며, 잎 은 피침형 또는 난상피침형으로 짧은 잎자루가 특징인 분 류군이다. Jo et al. (2014)에 의해 백두산 자생식물로 신종 발표되었으며, Kim et al. (2015)은 용늪을 신분포지로 보 고하였다. 백두산과 용늪에 자생하는 개체는 폐쇄화 유무 이외에는 다른 차이점이 없어 동일종으로 보는 견해(Kim, 2017; Jo, 2019)를 따랐다.

4. Pseudostellaria davidii (Franch.) Pax, Nat. Pflanzenfam., ed. 2. 16c: 318, 1934 (Fig. 4D).-TYPE: Korea. Geumgangsan Mt., U. Faurie s.n. (holotype: TI, photo!); Krascheninikovia davidii Franch., Pl. David. 1: 51, 1884; Stellaria davidii (Franch.) Hemsl., Journ. Linn. Soc. 23: 67, 1886.

Krascheninnikovia bulbosa Nakai, Bot. Mag. Tokyo 35: 133, 1921; Pseudostellaria bulbosa (Nakai) Nakai, Bull. Nat. Sci. Mus. Tokyo 31: 37, 1952.

국명: 덩굴개별꽃 Deong-gul-gae-byeol-kkot.

괴경은 방추형 또는 순무형으로 1-5개가 달리며, 길이 는 3-12 mm이고, 너비는 2-5 mm이다. 지상부 줄기는 1-8 개로 괴경을 통해 이웃하여 연결되어 있다. 식물체의 길 이는 49.0-75.0 cm이고 개화 초기에는 직립하나 덩굴성으 로 되며, 줄기의 털은 1-2줄이다. 하부 잎은 주걱형이고, 엽선은 예두이고, 엽신 길이는 $0.8-1.7 \mathrm{~cm}$ 이고 너비는 $0.2-$ $0.5 \mathrm{~cm}$ 이다. 중부 잎은 타원형이고, 엽선은 예두이고, 엽신 의 길이는 1.3-3.2 cm, 너비는 0.5-0.9 cm이다. 상부 잎은 대 생하고, 난형이며, 엽선은 예두이다. 엽신의 길이는 1.5$6.0 \mathrm{~cm}$, 너비는 $0.7-3.3 \mathrm{~cm}$ 로 잎 기부에 털이 있다. 엽병은 2.0-8.0 mm이다. 개화기는 4-6월이며, 꽃은 엽액에서 1-4 개 핀다. 소화경에는 1 줄의 털이 있으며, 개화기 소화경 길 이는 $1.0-4.8 \mathrm{~cm}$ 이고, 결실기 소화경의 길이는 $2.2-6.4 \mathrm{~cm}$ 이다. 꽃받침은 5개이고, 피침형으로 길이는 $3.4-5.5 \mathrm{~mm}$ 이고, 너비는 1.1-1.5 mm이며, 가장자리와 중륵에 털이 있 다. 꽃잎은 5장이고, 도란형으로 둔두이며, 길이는 3.7-8.7 $\mathrm{mm}$, 너비는 2.2-3.5 mm이다. 암술대의 수는 2-3개이고, 길 이는 3.7-6.0 mm이다. 수술의 수는 10 개이고, 길이는 2.3$5.5 \mathrm{~mm}$ 이며, 약은 자갈색으로 길이는 $0.4-0.6 \mathrm{~mm}$ 이다. 폐 쇄화는 엽액에 0-2개 달리며, 폐쇄화 소화경의 길이는 5$13 \mathrm{~mm}$ 이다. 열매는 삭과이며 6월 결실하며, 4-6개의 신장 형 또는 구형 종자가 들어있다. 종자 표면에 유두상 돌기
가 있으며, 길이는 2.1-2.3 mm, 너비는 1.7-2.0 mm이다.

국내분포: 경기, 강원, 충북, 충남, 전북, 전남, 경북, 경남, 대구, 함북.

국외분포: 중국, 러시아, 몽골.

생육지: 저지대-고지대(계곡 주변, 산지 숲속, 등산로 주변, 바위지대)의 건조하거나 습한 지형.

분류학적 검토: 덩굴개별꽃은 꽃받침 중륵에도 털이 있 고, 꽃잎은 5장으로 엽액에 꽃이 달리며, 개화기 이후 덩굴 성이 되는 특징을 가진다. 저지대-고지대, 다양한 생육 환경에 생육하므로 큰개별꽃, 태백개별꽃, 지리산개별꽃 등과 여러 지역에서 생육지가 중첩됨을 관찰하였다. 덩굴 개별꽃의 폐쇄화는 하부 엽액에 달리며(Lee, 1985), 그 수는 4개로 알려져 있지만(Lee, 1996a), 개방화 결실기 이후에 매 우 드물게 관찰되었으며, 폐쇄화 수는 최대 2개에 불과하 였다. 개화기 이후 덩굴성으로 변하는 보현개별꽃과 설악 개별꽃은 원줄기 상부와 곁가지의 잎이 다른 형태(난형의 잎과 장타원형-광타원형의 잎이 혼재)이고 종자 결실되 지 않는다는 점에서 차이를 보인다. 덩굴개별꽃의 괴경은 방추형과 순무형이며, 순무형 중에서 끝이 뭉뚝한 것은 구 형으로 보이는 등 변이가 관찰되므로, 덩이뿌리개별꽃을 덩굴개별꽃의 이명으로 보는 견해(Ohwi, 1937)를 따랐다.

5. Pseudostellaria okamotoi Ohwi, J. Jap. Bot. 12: 387, 1936. -TYPE: Korea. Chiisan Mt., J. Ohwi 6848 (holotype: KYO).

괴경은 방추형으로 $1-56$ 개가 달리며, 길이는 7-82 mm 이고, 너비는 1-4 mm이다. 지상부 줄기는 1-43개로 괴경 을 통해 이웃하여 연결되어 있다. 식물체의 높이는 5.0 $18.2 \mathrm{~cm}$ 이고 직립하거나 기부에서 굽어져 직립하며, 줄기 의 털은 1-2줄이다. 하부 잎은 주걱형이고, 엽선은 예두이 고, 엽신 길이는 $0.4-1.4 \mathrm{~cm}$ 이고 너비는 $0.2-0.3 \mathrm{~cm}$ 이다. 중 부 잎은 장타원형, 타원형, 도피침형, 주걱형이고, 엽선은 예두 또는 첨두이고, 엽신의 길이는 $1.9-7.1 \mathrm{~cm}$, 너비는 0.4-1.9 cm이다. 상부 잎은 위윤생하고, 장타원형, 타원형, 피침형, 난상피침형, 난형, 광타원형이며, 엽선은 예두, 첨 두, 점첨두이다. 엽신의 길이는 $2.5-8.4 \mathrm{~cm}$, 너비는 0.6$4.2 \mathrm{~cm}$ 로 잎 기부에 털이 있다. 엽병은 거의 없다. 개화기 는 4-5월이며, 꽃은 정단부에서 한개 핀다. 소화경에는 털 이 없거나 기부에 부분적으로 털이 있거나 또는 1-2줄의 털이 있으며, 개화기 소화경 길이는 2.3-6.3 cm이고, 결실 기 소화경의 길이는 $3.8-8.2 \mathrm{~cm}$ 이고, 줄기 기부 방향으로 소화경이 처진다. 꽃받침은 5-9개이고, 피침형으로 길이 는 4.0-6.9 mm이고, 너비는 1.0-2.0 mm이며, 기부 가장자리 에 털이 없거나 있다. 꽃잎은 5-9장이고, 타원형, 도란형, 광타원형으로 예두, 둔두이며, 길이는 $5.0-7.6 \mathrm{~mm}$, 너비는 2.5-4.8 mm이다. 암술대의 수는 2-5개이고, 길이는 3.2$5.9 \mathrm{~mm}$ 이다. 수술의 수는 10-18개이고, 길이는 2.9-4.7 mm 이며, 약은 자갈색으로 길이는 0.6-0.9 mm이다. 폐쇄화는 
엽액과 정단부에 2-13개 달리며, 폐쇄화 소화경의 길이는 10-32 mm이다. 열매는 삭과이며 5-6월 결실하며, 4-20개 의 신장형 또는 구형 종자가 들어있다. 종자 표면에 유두 상 돌기가 있으며, 길이는 $1.8-2.9 \mathrm{~mm}$, 너비는 $1.8-2.5 \mathrm{~mm}$ 이다.

1. 소화경에 털이 1-2줄 있고, 꽃잎은 5장이고, 괴경은 방추형이다. 1) var okamotoi

1. 소화경에 털이 없고, 꽃잎은 5-9장이고, 괴경은 가는 방추형이다.

2. 암술대는 직립하거나 완만하게 휘어진다.

3. 잎 기부에만 털이 있다.

2) var. longipedicellata f. longipedicellata

3. 상부 잎 표면 엽연, 잎 이면 중륵에 털이 있다. ...

...... 3) var. longipedicellata f. daegwallyeongensis

2. 암술대는 나선상으로 꼬여있다.

........ 4) var. longipedicellata f. palgongmolongiana

\section{1) Pseudostellaria okamotoi var. okamotoi (Fig. 5A).}

국명: 지리산개별꽃 Ji-ri-san-gae-byeol-kkot.

괴경은 방추형으로 1-21개가 달리며, 길이는 7-27 mm 이고, 너비는 1-4 mm이다. 지상부 줄기는 1-34개로 괴경 을 통해 이웃하여 연결되어 있다. 식물체의 높이는 5.0$16.0 \mathrm{~cm}$ 이다. 하부 잎의 엽신 길이는 $0.4-1.2 \mathrm{~cm}$ 이고 너비 는 0.2-0.3 cm이다. 중부 잎은 도피침형, 타원형이고, 엽선 은 예두 또는 첨두이고, 엽신의 길이는 $1.9-4.2 \mathrm{~cm}$, 너비는 0.4-1.0 cm이다. 상부 잎은 장타원형, 타원형, 피침형, 난상 피침형, 난형, 광타원형이며, 엽선은 예두, 첨두, 점첨두이 다. 엽신의 길이는 2.5-7.0 cm, 너비는 0.6-2.7 cm로 잎 기부 에 털이 있다. 개화기는 4-5월이다. 소화경에는 1-2줄의 털이 있으며, 개화기 소화경 길이는 2.3-6.3 cm이고, 결실 기 소화경의 길이는 $3.8-8.0 \mathrm{~cm}$ 이다. 꽃받침은 5 개이고, 길 이는 4.8-6.9 mm이고, 너비는 1.2-1.8 mm이다. 꽃잎은 5장 이고, 타원형, 도란형, 광타원형으로 예두, 둔두이며, 길이 는 5.1-7.6 mm, 너비는 2.8-4.8 mm이다. 암술대의 수는 2-3 개이고, 길이는 3.2-4.5 mm이다. 수술의 수는 10 개이고, 길 이는 3.7-4.7 mm이며, 약은 자갈색으로 길이는 0.6-0.8 mm 이다. 폐쇄화는 엽액과 정단부에 3-10개 달리며, 폐쇄화 소화경의 길이는 11-32 mm이다. 열매는 삭과이며 6월 결 실하며, 5-14개의 종자가 들어있다. 종자 길이는 1.8$2.4 \mathrm{~mm}$, 너비는 $1.8-2.1 \mathrm{~mm}$ 이다.

국내분포: 전북(세걸산, 덕유산), 전남(백운산), 경북(가 야산), 경남(지리산).

생육지: 고지대 능선, 산지 사면의 건조한 지형.

분류학적 검토: 지리산개별꽃은 상부 잎이 위윤생하는 분류군 중 꽃잎이 5장이고 소화경에 1-2줄의 털이 있으며, 결실기에 소화경이 길어져 줄기 기부로 처지는 특징이 있
다(Fig. $5 \mathrm{Ab}$ ). 식물체의 크기와 결실기에 소화경이 길어지 고, 줄기 기부로 처진다는 점에서 태백개별꽃과 특징을 공 유하나 꽃잎 수, 소화경의 털, 근경의 형태로 구별되었다.

2) Pseudostellaria okamotoi var. longipedicellata (S. Lee, K. I. Heo \& S. C. Kim) H. Jo f. longipedicellata in Kim, Korean Endemic Plants. 122, 2017 (Fig. 5B); Pseudostellaria longipedicellata S. Lee, K. I. Heo \& S. C. Kim, Novon 22: 25, 2012.-TYPE: Korea. Taebaeksan Mt., S. T. Lee. s.n. (holotype: SKK).

국명: 태백개별꽃 Tae-baek-gae-byeol-kkot.

괴경은 가는 방추형으로 3-56개가 달리며, 길이는 15$82 \mathrm{~mm}$ 이고, 너비는 1-2 mm이다. 지상부 줄기는 1-43개로 괴경을 통해 이웃하여 연결되어 있다. 식물체의 높이는 $5.3-18.2 \mathrm{~cm}$ 이다. 하부 잎의 엽신 길이는 0.4-1.4 cm이고 너 비는 0.2-0.3 cm이다. 중부 잎은 장타원형, 도피침형, 주걱 형이고, 엽선은 예두 또는 첨두이고, 엽신의 길이는 1.9$7.1 \mathrm{~cm}$, 너비는 0.6-1.9 cm이다. 상부 잎은 장타원형, 타원 형, 난상피침형, 난형, 광타원형이며, 엽선은 예두 또는 첨 두이다. 엽신의 길이는 $3.3-8.4 \mathrm{~cm}$, 너비는 $1.0-4.2 \mathrm{~cm}$ 로 잎 기부에 털이 있다. 엽병은 거의 없다. 개화기는 4-5월이다. 소화경에는 털이 없거나 기부에 부분적으로 털이 있으며, 개화기 소화경 길이는 2.7-6.1 cm이고, 결실기 소화경의 길이는 4.5-8.2 cm이다. 꽃받침은 5-9개이고, 길이는 4.0$6.1 \mathrm{~mm}$ 이고, 너비는 $1.0-2.0 \mathrm{~mm}$ 이다. 꽃잎은 5-9장이고, 도란형 또는 타원형으로 예두이며, 길이는 $5.0-7.3 \mathrm{~mm}$, 너 비는 2.5-3.2 mm이다. 암술대의 수는 2-5개이고, 길이는 4.0-5.9 mm이다. 수술의 수는 10-18개이고, 길이는 2.9-4.6 $\mathrm{mm}$ 이며, 약은 자갈색으로 길이는 0.7-0.9 mm이다. 폐쇄 화는 엽액과 정단부에 2-13개 달리며, 폐쇄화 소화경의 길이는 10-25 mm이다. 열매는 삭과이며 5-6월 결실하며, 4-20개의 종자가 들어있다. 종자 길이는 2.2-2.9 mm, 너비 는 $1.9-2.5 \mathrm{~mm}$ 이다.

국내분포: 강원, 충북, 전북(무주), 경북, 경남, 대구.

생육지: 고지대 능선, 산정상부, 산지 솦속, 계곡 주변.

분류학적 검토: 태백개별꽃은 큰개별꽃의 생태형으로 보는 견해(Choi, 1999)와 독립된 종으로 보는 견해(Lee et al., 2012), 지리산개별꽃의 변종으로 보는 견해(Kim, 2017; Jo, 2019) 등 종의 지위에 대한 견해차가 있는 분류군이다. 본 연구 결과 태백개별꽃은 식물체의 크기, 결실기 소화경의 길이, 줄기 기부 쪽으로 소화경이 처지는 특징, 폐쇄화 소 화경의 길이에서 지리산개별꽃과 유사한 특징을 보여 지 리산개별꽃의 변종으로 보는 견해를 따른다.

3) Pseudostellaria okamotoi var. longipedicellata f. daegwallyeongensis $\mathrm{H}$. Jo, f. nov. (Figs. 5C, 6A).-TYPE: Korea. Gangwon-do: Pyeongchang-gun, Daegwallyeong, 27 

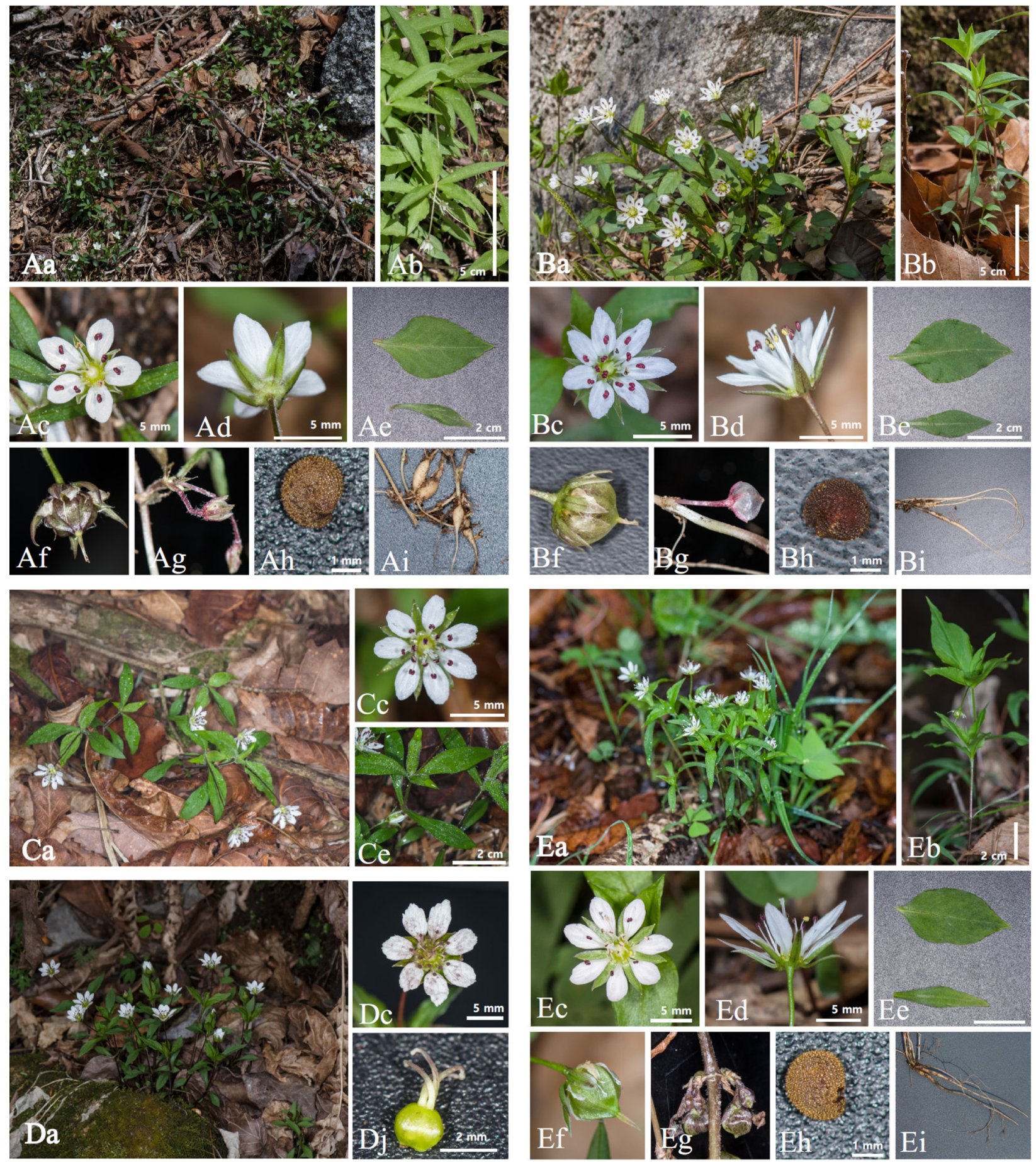

Fig. 5. Photographs of some Pseudostellaria species, variety, and forma plants in Korea. A. P. okamotoi var. okamotoi. B. P. okamotoi var. longipedicellata f. longipedicellata. C. P. okamotoi var. longipedicellata f. daegwallyeongensis. D. P. okamotoi var. longipedicellata f. palgongmolongiana. E. P. palibiniana var. palibiniana f. palibiniana. a. Habit. b. Inflorescence. c. Chasmogamic flower. d. Sepal \& pedicel. e. Leaf (above: distal leaf, below: middle leaf). f. Capsule. g. Cleistogamic flower. h. Seed. i. Tuber root. j. Pistil.

Apr 2016, H. Jo, JG42705 (holotype, JNU).

국명: 대관령개별꽃 Dae-gwal-lyeong-gae-byeol-kkot (국 명신칭).
Distal leaves subverticillate, pubescent on upper surface, margins, and on the midrib beneath.

상부 잎은 위윤생하며,표면과 엽연, 잎 이면 중륵에 털이 있다. 


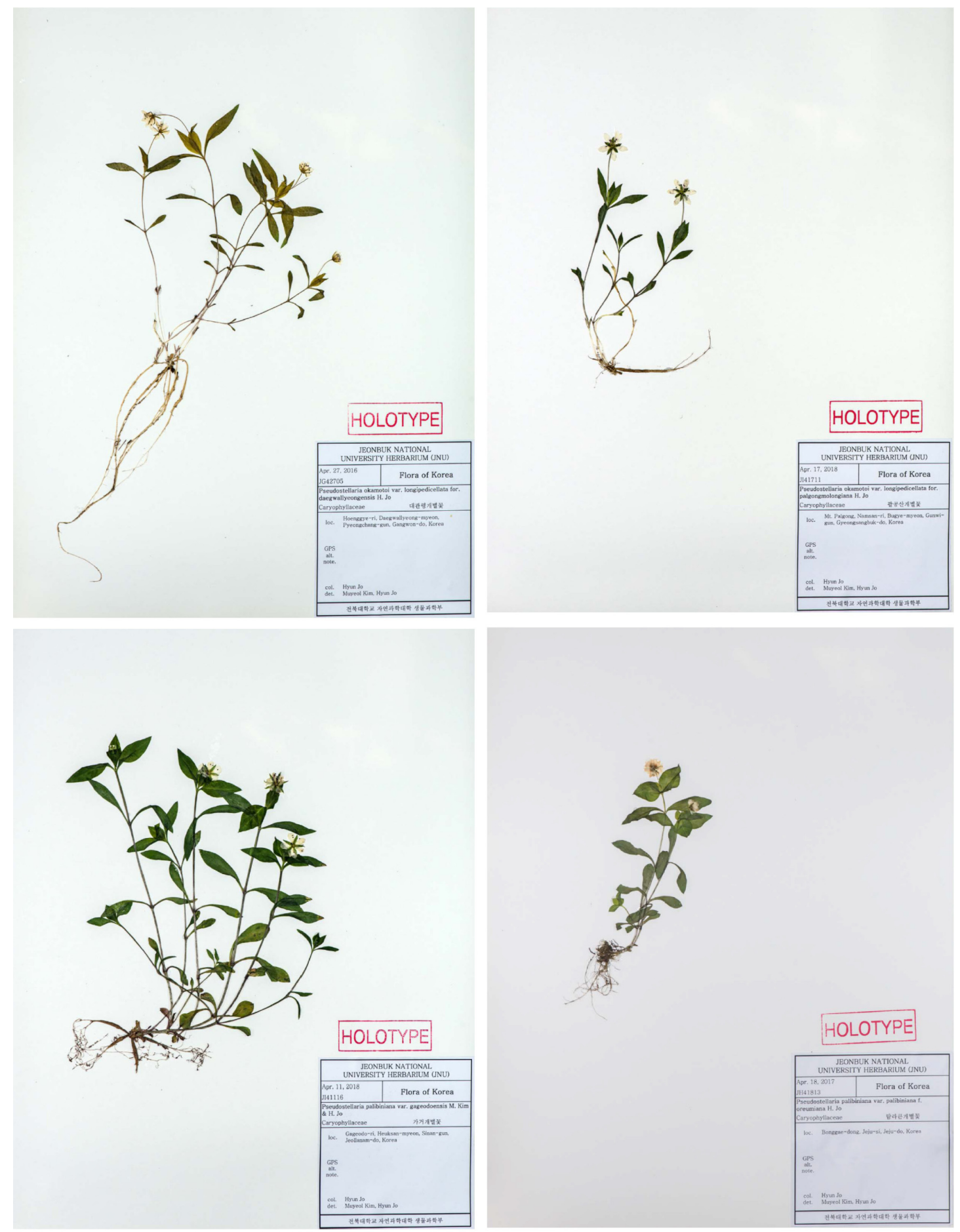

Fig. 6. Holotypes of Pseudostellaria variety and forma plants. A. P. okamotoi var. longipedicellata f. daegwallyeongensis. B. P. okamotoi var. longipedicellata f. palgongmolongiana. C. P. palibiniana var. gageodoensis. D. P. palibiniana var. palibiniana f. oreumiana.

국내분포: 강원(대관령).

분류학적 검토: 대관령개별꽃은 상부 잎의 표면과 엽연, 잎 이면 중륵에 털이 있어 태백개별꽃과 구별된다. 털 이 외의 주요 형질은 태백개별꽃과 동일하여 품종으로 처리
하고, 생육 지역 이름을 따서 대관령개별꽃으로 하였다.

4) Pseudostellaria okamotoi var. longipedicellata f. palgongmolongiana H. Jo, f. nov. (Figs. 5D, 6B).-TYPE: 
Korea. Gyeongsangbuk-do: Gunwi-gun, Palgongsan Mt., 17 Apr 2018, H. Jo, JI41711 (holotype, JNU).

국명: 팔공산개별꽃 Pal-gong-san-gae-byeol-kkot (국명신칭).

Styles 1.9-3.0 mm long, spiral style. Stamen $1.7-4.0 \mathrm{~mm}$ long.

암술대 길이는 1.9-3.0 mm이고 나선상으로 꼬여 있고, 수술 길이는 $1.7-4.0 \mathrm{~mm}$ 이다.

국내분포: 경북(팔공산).

분류학적 검토: 팔공산개별꽃은 개방화 결실, 폐쇄화 결실, 괴경의 수 증가, 지상부 줄기의 포복에 의한 개체 증 가 등 다양한 방식으로 태백개별꽃처럼 번식하는 것으로 관찰되었다. 특히 태백개별꽃과 유사한 특징을 보이는 분 류군들은 단독으로 생육하지 않고 한번에 큰 군락을 이루 어 넓게 분포하는데, 이러한 특징이 팔공산에서도 관찰되 었다. 팔공산개별꽃은 암술대가 나선상으로 꼬여 있고, 암술대와 수술의 길이가 짧으며, 꽃받침 너비가 넓어서 태백개별꽃이나 큰개별꽃과 뚜렷하게 구별되었다(Fig. 5Dj, Table 2).

6. Pseudostellaria palibiniana (Takeda) Ohwi, Act. Phytotax. Geobot. 4: 32, 1935; Krascheninikovia palibiniana Takeda, Kew Bull. 1913: 89, 1913.-TYPE: Korea. Near Seoul, Sontag s.n. (syntype: K, photo!). Japan. Hondo, Bisset, Takeda s.n. (syntype: ?).

Krascheninikovia coreana Nakai, Feddes Repert. Spec. Nov. Regni Veg. 13: 268, 1914.-TYPE: Korea. Jeju, E. Taquet $n$. 6054 (holotype: ?, photo!); Pseudostellaria coreana (Nakai) Ohwi, J. Jap. Bot. 12: 387, 1936.

Krascheninikovia palibiniana var. polymera Nakai, Bot. Mag. (Tokyo) 35: 133, 1921; Pseudostellaria polymera (Nakai) Nakai, Bull. Nat. Sci. Mus. Tokyo 31: 37, 1952.

Pseudostellaria monantha Ohwi, J. Jap. Bot. 12: 386, 1936.

-TYPE: Korea Jeju, Ohwi 9201 (holotype: KYO).

1. 소화경에 털이 없다. 꽃받침 길이는 $7.0 \mathrm{~mm}$ 미만이다. 2. 개방화는 암술과 수술이 있고, 꽃잎이 5-9장이다.

3. 잎 기부에만 털이 있다.

1) var palibiniana f. palibiniana

3. 상부 잎 표면, 엽연, 잎 이면 중륵에 털이 있다. ·.

2) var palibiniana $\mathrm{f}$. hallasanensis

2. 개방화는 암술과 수술이 퇴화되어 겹꽃으로 핀다. .... 3) var palibiniana f. oreumiana

1. 소화경에 털이 1-2줄 있다. 꽃받침 길이는 $7.0 \mathrm{~mm}$ 이 상이다. 4) var. gageodoensis

괴경은 가는 방추형 또는 방추형으로 1-56개가 달리며, 길이는 10-80 mm이고, 너비는 1-5 mm이다. 지상부 줄기
는 1-17개로 괴경을 통해 이웃하여 연결되어 있다. 식물 체의 높이는 6.0-25.0 cm이고 직립하거나 기부에서 굽어 져 직립하며, 줄기의 털은 1-2줄이다. 하부 잎은 주걱형이 고, 엽선은 예두이고, 엽신 길이는 $0.5-1.4 \mathrm{~cm}$ 이고 너비는 0.2-0.3 cm이다. 중부 잎은 장타원형, 타원형, 도피침형이 고, 엽선은 예두 또는 첨두이고, 엽신의 길이는 $2.3-7.1 \mathrm{~cm}$, 너비는 0.5-2.0 cm이다. 상부 잎은 위윤생하고, 타원형, 피 침형, 난상피침형, 난형, 광타원형이며, 엽선은 예두, 첨두, 점첨두이다. 엽신의 길이는 $2.6-7.3 \mathrm{~cm}$, 너비는 $1.2-4.3 \mathrm{~cm}$ 로 잎 기부에 털이 있다. 엽병은 거의 없다. 개화기는 4-5 월이며, 꽃은 정단부에서 한개 핀다. 소화경에는 털이 없 거나 1-2줄의 털이 있고, 개화기 소화경 길이는 $1.0-2.7 \mathrm{~cm}$ 이고, 결실기 소화경의 길이는 $1.3-2.8 \mathrm{~cm}$ 이다. 꽃받침은 5-9개이고, 피침형으로 길이는 4.5-9.0 mm이고, 너비는 1.0-2.8 mm이며, 털이 없거나 기부 가장자리에 털이 있다. 꽃잎은 5-9장이고, 도란형 또는 타원형으로 예두, 둔두, 결 각상이며, 길이는 5.4-12.0 mm, 너비는 $1.9-6.0 \mathrm{~mm}$ 이다. 암 술대의 수는 3-5개이고, 길이는 3.4-6.5 mm이다. 수술의 수는 10-18개이고, 길이는 3.5-5.8 mm이며, 약은 자갈색으 로 길이는 0.5-0.8 mm이다. 폐쇄화는 엽액과 정단부에 225 개 달리며, 폐쇄화 소화경의 길이는 4-14 mm이다. 열매 는 삭과이며 5-6월 결실하며, 5-15개의 구형 종자가 들어 있다. 종자 표면에 유두상 돌기가 있으며, 길이는 2.1$2.8 \mathrm{~mm}$, 너비는 $1.9-2.5 \mathrm{~mm}$ 이다.

1) Pseudostellaria palibiniana var. palibiniana f. palibiniana. (Fig. 5E).

국명: 큰개별꽃 Keun-gae-byeol-kkot.

괴경은 가는 방추형 또는 방추형으로 2-56개가 달리며, 길이는 13-80 mm이고, 너비는 1-3 mm이다. 지상부 줄기 는 1-17개로 괴경을 통해 이웃하여 연결되어 있다. 식물 체의 높이는 6.0-25.0 cm이다. 하부 잎의 엽신 길이는 0.5$1.3 \mathrm{~cm}$ 이고 너비는 $0.2-0.3 \mathrm{~cm}$ 이다. 중부 잎은 장타원형, 타원형, 도피침형이고, 엽선은 예두 또는 첨두이고, 엽신 의 길이는 2.3-7.1 cm, 너비는 0.5-1.6 cm이다. 상부 잎은 위 윤생하고, 타원형, 피침형, 난상피침형, 난형, 광타원형이 며, 엽선은 예두, 첨두, 점첨두이다. 엽신의 길이는 2.6$7.3 \mathrm{~cm}$, 너비는 $1.2-4.3 \mathrm{~cm}$ 로 잎 기부에 털이 있다. 엽병은 거의 없다. 개화기는 4-5월이다. 소화경에는 털이 없으며, 개화기 소화경 길이는 $1.4-2.7 \mathrm{~cm}$ 이고, 결실기 소화경의 길이는 1.4-2.8 cm이다. 꽃받침은 5-8개이고, 길이는 4.5$6.5 \mathrm{~mm}$ 이고, 너비는 $1.0-1.7 \mathrm{~mm}$ 이며, 털이 없거나 기부 가 장자리에 털이 있다. 꽃잎은 5-8장이고, 도란형 또는 타원 형으로 예두, 결각상이며, 길이는 5.4-7.9 mm, 너비는 1.9$3.1 \mathrm{~mm}$ 이다. 암술대 길이는 3.4-6.5 mm이다. 수술의 수는 $10-16$ 개이고, 길이는 $3.5-5.8 \mathrm{~mm}$ 이며, 약은 자갈색으로 길 이는 0.5-0.8 mm이다. 폐쇄화는 엽액과 정단부에 2-14개 

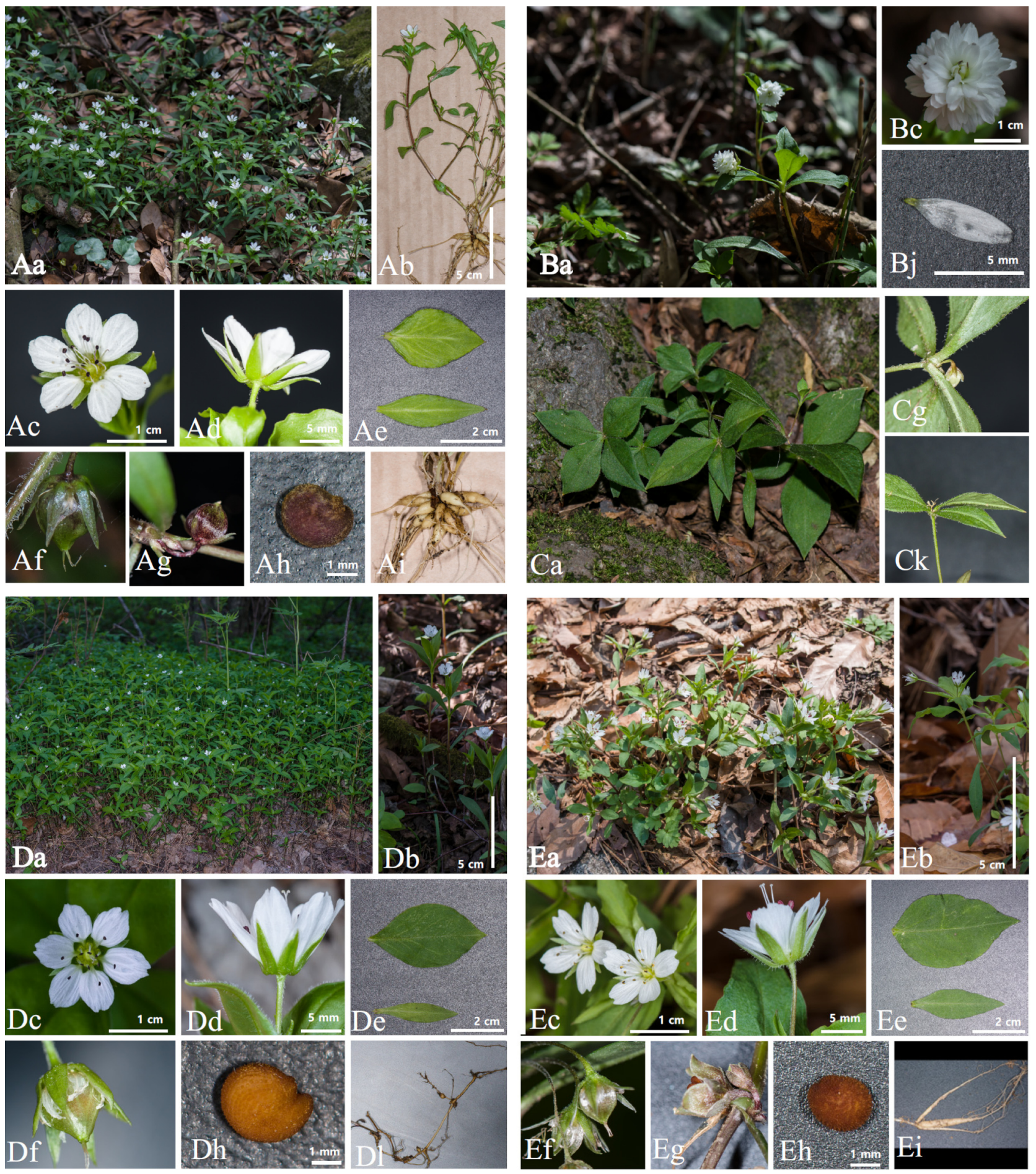

Fig. 7. Photographs of some Pseudostellaria species, variety, and forma plants in Korea. A. P. palibiniana var. gageodoensis. B. P. palibiniana var. palibiniana f. oreumiana. C. P. palibiniana var. palibiniana f. hallasanensis. D. P. setulosa. E. P. heterophylla f. heterophylla. a. Habit. b. Inflorescence. c. Chasmogamic flower. d. Sepal \& pedicel. e. Leaf (above: distal leaf, below: middle leaf). f. Capsule. g. Cleistogamic flower. h. Seed. i. Tuber root. j. Petal. k. Distal leaf. I. Rhizome \& tuber root.

달리며, 폐쇄화 소화경의 길이는 4-14 $\mathrm{mm}$ 이다. 열매는 삭 과이며 5-6월 결실하며, 6-15개의 구형 종자가 들어있다.
종자 길이는 2.1-2.6 mm, 너비는 1.9-2.4 mm이다.

국내분포: 경기, 강원, 전북, 전남, 경북, 경남, 부산, 제주. 
국외분포: 일본.

생육지: 저지대 산지 또는 고지대(지리산, 백운산, 한라산).

분류학적 검토: 큰개별꽃은 가는 방추형의 괴경이 특징 이나(Mizushima, 1965) 남부 지역 중 담양, 거제, 부산, 제주 개체는 짧고 굵은 형태의 방추형 개체가 널리 분포하였고, 남부 지역 중 남원, 광양, 완도는 일반적인 형태의 가는 방 추형 개체가 생육하는 것으로 관찰되었다. 산개별꽃과 참 개별꽃은 제주도에서 채집된 표본을 근거로 신종 기재되 었다. 산개별꽃은 뿌리는 방추형이고 비후하며, 소화경에 는 털이 없고, 꽃잎은 도피침형이고 예두이며, 폐쇄화 수가 적다는 점을 차이점으로 보았으나, 제주도 한라산과 주변 오름 일대의 생육개체를 확인한 결과 짧고 굵은 방추형의 뿌리는 원기재와 동일하나, 꽃잎 수, 꽃잎 정단부 모양, 폐 쇄화 수 등에서 의미 있는 차이점을 발견할 수 없었다. 또한 큰개별꽃의 폐쇄화 수는 2 (7.6) 14개 나타나며, 유사한 특징 을 지닌 지리산개별꽃(3 [7.0] 10개), 태백개별꽃(2 [5.0] 13 개)과 비슷하여, 폐쇄화 수가 분류군간 차이를 보여주는 형 질로 보기 어려운 것으로 나타났다. 따라서 본 연구에서는 산개별꽃을 큰개별꽃과 동일종으로 보는 견해를 따랐다 (Ohwi, 1937). 참개별꽃은 개별꽃의 이명으로 처리하는 견 해가 있으나(Ohwi, 1937; Mizushima, 1965), 기준표본의 식물 체 외형이 큰개별꽃과 같고, 한라산과 인근 오름의 생육 개 체는 큰개별꽃이므로, 큰개별꽃과 같은 종으로 보는 Choi (1999)의 견해를 따랐다. 큰개별꽃은 지리산개별꽃, 태백개 별꽃과 유사하나, 개방화 소화경이 짧고 줄기 기부로 구부 러지지 않으며, 폐쇄화 소화경도 짧아서 구별되었다.

2) Pseudostellaria palibiniana var. palibiniana f. hallasanensis H. Jo, f. nov. (Figs. 7C, 8).-TYPE: Korea. Jejudo Island, 30 Aug 2017, H. Jo, JH83004 (holotype, JNU).

국명: 영선큰개별꽃 Yeong-seon-keun-gae-byeol-kkot (국 명신칭).

Distal leaves subverticillate, pubescent on upper surface, margins, and on the midrib beneath.

상부 잎 표면과 엽연, 잎 이면 중륵에 털이 있다.

국내분포: 한국(제주).

분류학적 검토: 영선큰개별꽃은 상부 잎의 표면과 엽연, 잎 이면 중륵에 털이 있어 큰개별꽃과 구별된다. 큰개별 꽃 군락과 이웃하여 군락을 형성하고 있으며, 유성생식( 개방화, 폐쇄화)과 무성생식(지상부 줄기, 괴경)을 통해 번식하므로 인위적인 간섭이 없다면, 안정적인 군락이 유 지될 것으로 여겨진다.

3) Pseudostellaria palibiniana var. palibiniana f. oreumiana H. Jo, f. nov. (Figs. 6D, 7B).-TYPE: Korea. Jejudo Isl., 18 Apr 2017, H. Jo, JH41813 (holotype, JNU).

국명: 탐라큰개별꽃 Tam-ra-keun-gae-byeol-kkot (국명신칭).

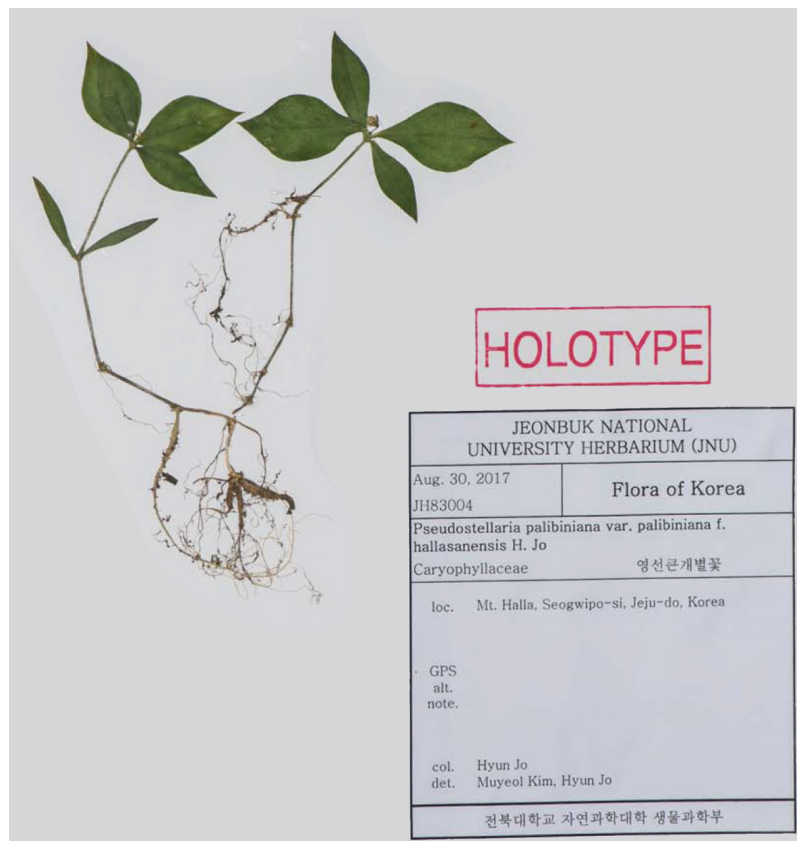

Fig. 8. Holotype of Pseudostellaria palibiniana var. palibiniana f. hallasanensis.

Chasmogamic flowers terminal and solitary, double-petal flowers.

꽃은 정단부에 1 개 피며, 겹꽃이다.

국내분포: 한국(제주).

분류학적 검토: 탐라큰개별꽃은 암술과 수술이 퇴화되 었으며 겹꽃으로 핀다.

4) Pseudostellaria palibiniana var. gageodoensis $\mathrm{M}$. Kim \& H. Jo, var. nov. (Figs. 6C, 7A, 9).-TYPE: Korea. Jeollanam-do: Sinan-gun, Gageodo Island, 11 Apr 2018, elev. $570 \mathrm{~m}$, H. Jo, JI41116 (holotype, JNU; isotypes, JNU, KH).

국명: 가거개별꽃 Ga-geo-gae-byeol-kkot (국명신칭).

Diagnosis: Pseudostellaria palibiniana var. gageodoensis M. Kim \& H. Jo can be distinguished from its related taxa $P$. palibiniana var. palibiniana by having 1-2 rows of trichomes on the pedicel, large sepal size, large petal size, and branched stem at its base.

Perennial herbs; rhizomatous with 1-9 aerial stem; root tubers fusiform, 1-16, 10-27 $\mathrm{mm} \times 2-5 \mathrm{~mm}$. Plant erect or basally decumbent and stem branched, $8.9-25.0 \mathrm{~cm}$, with 12 lines vertical rows of trichomes. Proximal leaves spatulate, apex acute, $0.5-1.4 \mathrm{~cm} \times 0.2-0.3 \mathrm{~cm}$; middle leaves oblong, elliptic, apex acute, cuspidate, acuminate, length $3.5-5.2 \mathrm{~cm} \times$ 0.9-2.0 cm; distal leaves subverticillate, elliptic, ovate, oval, 


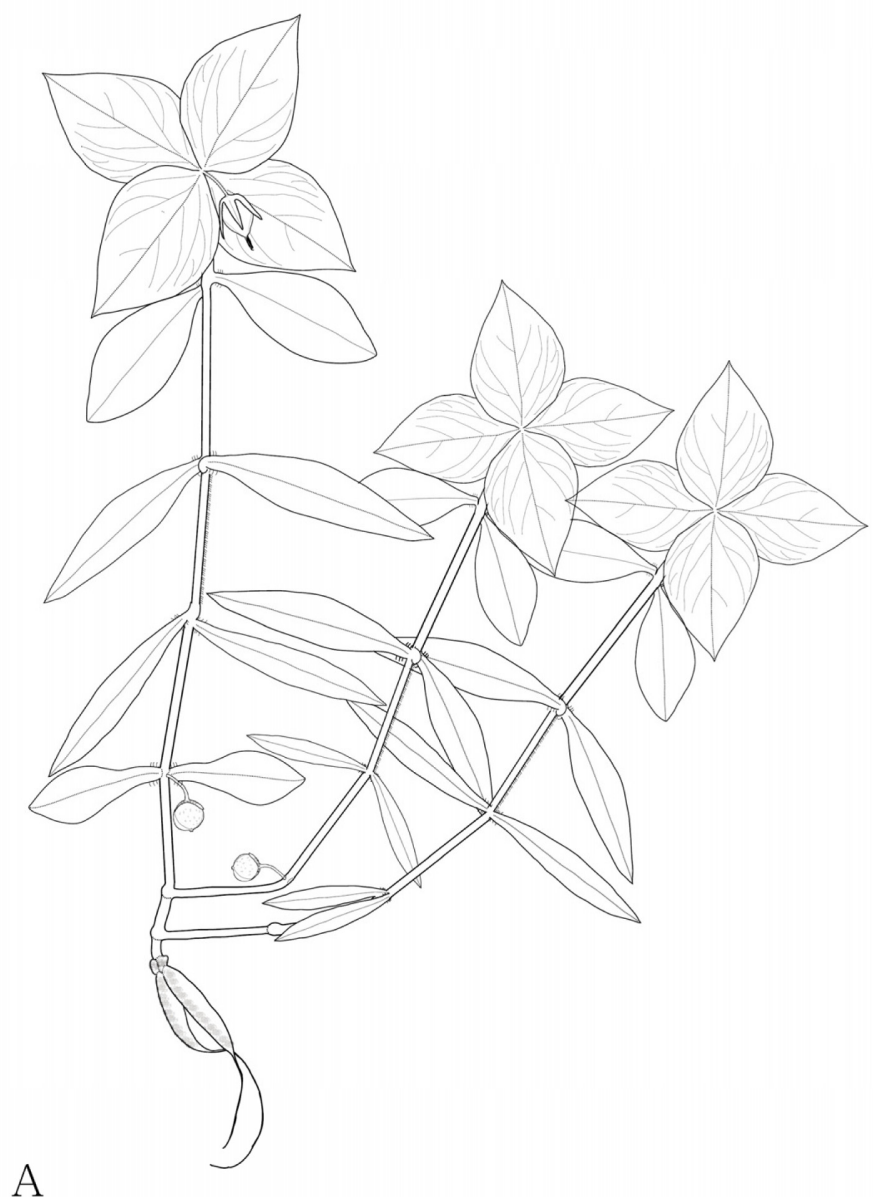

B

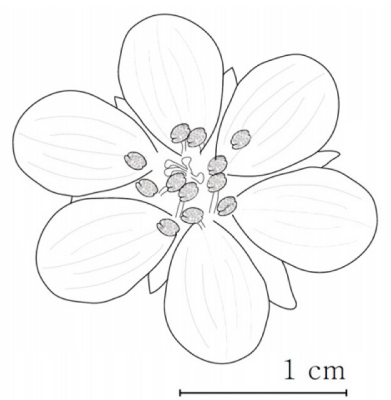

D

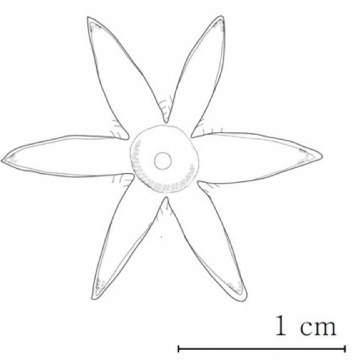

C

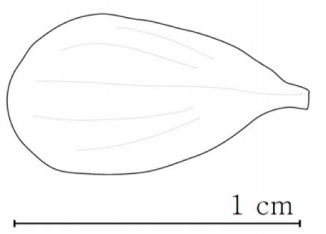

A
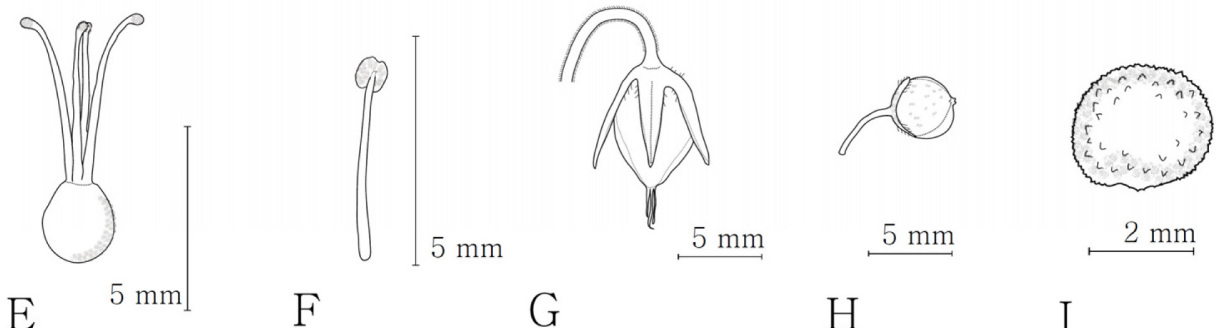

G

$\mathrm{H}$

I

Fig. 9. Illustration of Pseudostellaria palibiniana var. gageodoensis. A. Habit. B. Chasmogamic flower. C. Sepal. D. Petal. E. Pistil. F. Stamen. G. Capsule. H. Cleistogamic flower. I. Seed.

apex acute, cuspidate, $2.7-4.7 \mathrm{~cm} \times 1.3-2.7 \mathrm{~cm}$, with margin pubescent at base, petiole near sessile. Chasmogamic flowers terminal and solitary, pedicel $1.0-2.1 \mathrm{~cm}$ long, 1-2 lines vertical rows of trichomes, fruit pedicel length $1.3-2.2 \mathrm{~cm}$. Sepals lanceolate, 5-9, length 7-9 $\mathrm{mm} \times 1.5-2.8 \mathrm{~mm}$, with basal margin pubescent. Petals obovate, apex obtuse, bitten, $5-9,7.5-12.0 \mathrm{~mm} \times 4.2-6.0 \mathrm{~mm}$. Styles 3-5, 3.7-5.5 $\mathrm{mm}$ long.
Stamens 10-18, 3.9-5.5 mm long; Anther purple-brown, 0.6$0.8 \mathrm{~mm}$ long. Cleistogamic flower axillary on stem and terminal, 3-25, pedicel 7-9 mm long. Capsule with 5-10 seeds. Seeds subglobose, brown, with mammillate, $2.5-2.8 \mathrm{~mm} \times$ 2.1-2.5 mm.

Flowering: Apr.

Fruiting: May. 
Distribution: South Korea (Gageodo Isl., Sinan-gun, Jeollanam-do).

Habitats: This species grows along the forest trail in Gageodo Island.

괴경은 방추형으로 1-16개 달리며, 길이는 10-27 mm이 고, 너비는 2-5 mm이다. 지상부 줄기는 1-9개로 괴경을 통 해 이웃하여 연결되어 있다. 식물체의 높이는 $8.9-25.0 \mathrm{~cm}$ 이다. 하부 잎의 엽신 길이는 0.5-1.4 cm이고 너비는 0.2$0.3 \mathrm{~cm}$ 이다. 중부 잎은 장타원형, 타원형이고, 엽선은 예두, 첨두, 점첨두이고, 엽신의 길이는 $3.5-5.2 \mathrm{~cm}$, 너비는 0.9$2.0 \mathrm{~cm}$ 이다. 상부 잎은 위윤생하고, 타원형, 난형, 광타원 형이며, 엽선은 예두 또는 첨두이다. 엽신의 길이는 2.7$4.7 \mathrm{~cm}$, 너비는 1.3-2.7 cm로 잎 기부에 털이 있다. 개화기는 4월이며, 꽃은 정단부에 1 개 핀다. 소화경에는 1-2줄의 털 이 있으며, 개화기 소화경 길이는 1.0-2.1 cm이고, 결실기 소 화경의 길이는 $1.3-2.2 \mathrm{~cm}$ 이다. 꽃받침은 5-9개이고, 피침형 으로 길이는 7-9 mm이고, 너비는 $1.5-2.8 \mathrm{~mm}$ 이며, 기부 가 장자리에 털이 있다. 꽃잎은 5-9장이고, 도란형으로 둔두, 결각상이며, 길이는 7.5-12.0 mm, 너비는 4.2-6.0 mm이다. 암술대의 수는 3-5개이고, 길이는 3.7-5.5 mm이다. 수술의 수는 10-18개이고, 길이는 3.9-5.5 mm이며, 약은 자갈색으 로 길이는 0.6-0.8 mm이다. 폐쇄화는 엽액과 정단부에 3-25 개 달리며, 폐쇄화 소화경의 길이는 7-9 mm이다. 열매는 삭 과이며 5월 결실하며, 5-10개의 구형 종자가 들어있다. 종 자 길이는 $2.5-2.8 \mathrm{~mm}$, 너비는 $2.1-2.5 \mathrm{~mm}$ 이다.

국내분포: 전남(가거도).

생육지: 산지 숲속 및 등산로 주변.

분류학적 검토: 가거개별꽃은 소화경에 1-2줄의 털이 있고, 꽃받침 길이와 너비, 꽃잎의 길이와 너비가 더 크고, 개화기에 줄기 기부에서 분지되는 특징을 보여 근연 분류 군과 쉽게 구별되었다(Fig. 7Ab, Table 2).

7. Pseudostellaria setulosa Ohwi, J. Jap. Bot. 12: 388, 1936 (Fig. 7D).-TYPE: Korea. Geumgangsan Mt., Ohwi 60 (holotype: KYO).

국명: 솦개별꽃 Sup-gae-byeol-kkot.

뿌리는 근경과 괴경으로 이루어져 있으며, 근경을 통해 번식하며, 근경의 중간에서 구형, 타원형, 곤봉형 등의 괴 경이 달린다. 괴경의 길이는 2-13 $\mathrm{mm}$ 이고, 너비는 2$5 \mathrm{~mm}$ 이다. 식물체의 높이는 9.4-21.0 cm이고 직립하거나 기부에서 굽어져 직립하며, 줄기의 털은 1-2줄이다. 하부 잎은 도피침형 또는 주걱형이고, 엽선은 예두이고, 엽신 길이는 $0.7-1.7 \mathrm{~cm}$ 이고 너비는 $0.2-0.3 \mathrm{~cm}$ 이다. 중부 잎은 장타원형, 타원형이고, 엽선은 예두 또는 첨두이고, 엽신 의 길이는 2.5-6.7 cm, 너비는 0.7-2.7 cm이다. 상부 잎은 위 윤생하고, 타원형, 난상피침형, 난형, 광타원형이며, 엽선
은 예두 또는 첨두이다. 엽신의 길이는 3.8-10.1 cm, 너비 는 1.9-5.1 cm로 엽연과 잎 이면 중륵에 털이 있다. 엽병은 거의 없다. 개화기는 4-5월이며, 꽃은 정단부에서 한개 핀 다. 소화경에는 2 줄의 털이 있으며, 개화기 소화경 길이는 $1.0-2.7 \mathrm{~cm}$ 이고, 결실기 소화경의 길이는 $1.5-2.7 \mathrm{~cm}$ 이다. 꽃받침은 6 개이고, 피침형으로 길이는 $4.5-8.2 \mathrm{~mm}$ 이고, 너 비는 1.4-2.1 mm이며, 기부 가장자리에 털이 있다. 꽃잎은 6장이고, 도란형으로 얕은 요두 또는 결각상이며, 길이는 7.0-11.0 mm, 너비는 3.0-5.0 mm이다. 암술대의 수는 2-3개 이고, 길이는 4.2-6.2 mm이다. 수술의 수는 12 개이고, 길이 는 4.0-6.0 mm이며, 약은 자갈색으로 길이는 $0.5-0.8 \mathrm{~mm}$ 이 다. 폐쇄화는 없다. 열매는 삭과이며 6월 결실하며, 1-8개 의 신장형 또는 구형 종자가 들어있다. 종자 표면에 유두상 돌기가 있으며, 길이는 2.5-3.8 mm, 너비는 2.3-2.9 mm이다.

국내분포: 강원, 충북, 경북(봉화)

생육지: 고지대 능선 및 산지 솦속, 계곡 주변

분류학적 검토: 숲개별꽃은 꽃잎이 6장이고 엽연과 이 면 중륵에 털이 있으며, 지하경을 통해 번식하며, 폐쇄화 가 달리지 않는다는 점에서 다른 분류군과 구별된다. 과 거 P. sylvatica를 숲개별꽃 또는 가는잎개별꽃으로 혼용해 서 부르고, P. setulosa를 털개별꽃 또는 숲개별꽃으로 부르 는 등 국명의 혼선이 있었다. Lee (1996b)는 국명의 발표 시기가 1969년으로 앞선 털개별꽃을 정명으로 하고 1974 년인 숲개별꽃을 이명으로 하였다. 본 연구에서는 솦개별 꽃을 국명으로 하는 견해를 따랐다(Park, 1974; Choi, 1999; Choi, 2007; Jo et al., 2014; Kim, 2017, Jo, 2019).

8. Pseudostellaria heterophylla (Miq.) Pax in Engl. \& Prantl, Nat. Pflanzenfam ed. 2. 16c: 318, 1934; Krascheninnikovia heterophylla Miq., Ann. Mus. Bot. Lugduno-Batavi 3: 187, 1867.-TYPE: Oldham s.n. (syntype: ?, photo!); Stellaria heterophylla (Miq.) Hemsl., Journ. Linn. Soc. 23: 68, 1886.

Krascheninnikovia maximowicziana Franch. \& Sav., Enum Pl. Jap. 297, 1879; Pseudostellaria maximowicziana (Franch. \& Sav.) Pax in Engl. \& Prantl, Nat. Pflanzenfam. 16c: 318, 1934.

Stellaria rhaphanorrhiza Hemsl., Journ. Linn. Soc. 23: 69, 1886; Krascheninnikovia raphanorrhiza (Hems1.) Korsh., Bul1. Acad. Sci. St. Petersb. 9: 39 et 391, 1898; Pseudostellaria raphanorrhiza (Hems1.) Pax in Engl. \& Prantl, Nat. Pflanzenfam. 16c: 318, 1934.

Krascheninnikovia koidzumiana Ohwi, Act. Phytotax. et Geobot. 3: 82, 1934; Pseudostellaria koidzumiana (Ohwi) Ohwi, Act. Phytotax. et Geobot. 4: 33, 1935.

Pseudostellaria musashiensis Hiyama, J. Jap. Bot. 26: 287, 1951.

1. 잎 기부에만 털이 있다. 1) f. heterophylla

1. 잎 표면, 엽연, 잎 이면 중륵에 털이 있다.

2) f. puberula 
1) Pseudostellaria heterophylla f. heterophylla (Fig. 7E). 국명: 개별꽃 Gae-byeol-kkot.

괴경은 방추형으로 1-4개가 달리며, 길이는 $10-55 \mathrm{~mm}$ 이고, 너비는 2-5 mm이다. 지상부 줄기는 하나이다. 식물 체의 높이는 8.9-27.0 cm이고 직립하거나 기부에서 굽어 져 직립하며, 줄기의 털은 1-2줄이다. 하부 잎은 주걱형 이고, 엽선은 예두이고, 엽신 길이는 $0.5-1.6 \mathrm{~cm}$ 이고 너비 는 0.2-0.3 cm이다. 중부 잎은 장타원형, 도피침형이고, 엽선은 예두 또는 첨두이고, 엽신의 길이는 $3.0-7.3 \mathrm{~cm}$, 너 비는 0.5-1.3 cm이다. 상부 잎은 위윤생하고, 장타원형, 난상피침형, 난형, 광타원형이며, 엽선은 예두, 첨두, 점 첨두이다. 엽신의 길이는 $4.0-10.0 \mathrm{~cm}$, 너비는 $1.5-4.8 \mathrm{~cm}$ 로 잎 기부에 털이 있다. 엽병은 거의 없다. 개화기는 5월 이며, 꽃은 정단부에서 1-8개 핀다. 소화경 전체에 털이 있으며, 개화기 소화경 길이는 $1.2-3.0 \mathrm{~cm}$ 이고, 결실기 소 화경의 길이는 $1.2-3.0 \mathrm{~cm}$ 이다. 꽃받침은 5 개이고, 피침 형으로 길이는 4.6-7.5 mm이고, 너비는 1.2-2.2 mm이며, 가장자리와 중륵에 털이 있다. 꽃잎은 5 장이고, 도란형 또는 타원형으로 얕은 요두, 결각상, 예두, 둔두이며, 길 이는 5.9-8.0 mm, 너비는 3.3-5.0 mm이다. 암술대의 수는 2-3개이고, 길이는 4.5-6.3 mm이다. 수술의 수는 10 개이 고, 길이는 4.5-5.8 mm이며, 약은 자갈색으로 길이는 1.1$1.3 \mathrm{~mm}$ 이다. 폐쇄화는 엽액과 정단부에 5-32개 달리며, 폐쇄화 소화경의 길이는 $3-9 \mathrm{~mm}$ 이다. 열매는 삭과이며 5 월 결실하며, 4-19개의 신장형 또는 구형 종자가 들어있 다. 종자 표면에 유두상 돌기가 있으며, 길이는 2.0$2.2 \mathrm{~mm}$, 너비는 1.4-1.9 mm이다.

국내분포: 인천, 경기, 강원, 충북, 충남, 대전, 전북, 전남, 경북, 경남, 대구

국외분포: 중국, 일본, 네팔

생육지: 산지 솦속 및 등산로 주변, 계곡 주변

분류학적 검토: 관찰 시점에 따른 괴경의 수 변화와 꽃 잎 정단부의 형태상의 다양성에 의해 인식 형질로 보기 어 려운 것으로 나타났다. 괴경은 개화기에는 1 개 또는 드물 게 2 개가 관찰되었으나 결실기 이후에는 흔히 2 개, 많게는 4 개까지 관찰되었으며, 꽃잎은 요두, 결각상, 예두, 둔두 등 다양하게 관찰되었다(Table 1-2). 개별꽃은 화경 전체에 털 이 있고, 꽃잎은 5장이고 꽃이 (1)2-5(8)송이 달린다는 점에 서 다른 분류군과 뚜렷하게 구별되었다.

2) Pseudostellaria heterophylla f. puberula (Ohwi) M. Mizush., Bull. Bot. Surv. India. 7: 67, 1956--TYPE: Korea. Hamyang, J. Ohwi s.n. (holotype: ?); P. heterophylla var. puberula Ohwi, Jap. Bot. 9: 100, 1937.

국명: 털개별꽃 Teol-gae-byeol-kkot.

잎 표면에 털과 엽연, 이면 중륵위에 털이 있다.
국내분포: 경남(함양).

분류학적 검토: 털개별꽃(P. heterophylla var. puberula)은 경남 함양에서 채집되었고, 잎 표면과 엽연, 잎 이면 맥에 털이 있어 신변종 기재되었다. Mizushima (1965)는 한 장 소에서만 발견되고 자신만의 분포역을 가지지 않는다는 점을 들어 품종 처리하였고, Choi (1999)는 품종으로 보는 견해를 지지했다. 본 연구 기간 동안 털개별꽃을 관찰하 지 못하였다.

9. Pseudostellaria $\times$ bohyeonsanensis $\mathrm{M}$. Kim \& H. Jo, nothosp. nov. (Figs. 10A, 11A, 12).-TYPE: Korea. Gyeongsangbuk-do: Cheongsong-gun, Bohyeonsan Mt., elev. 1,050 m, 25 May 2016, H. Jo, JG52502 (holotype, JNU; isotypes, $\mathrm{JNU}, \mathrm{KH}$ ).

Hybrid parents: Pseudostellaria davidii $\times$ P. okamotoi var. longipedicellata

"Pseudostellaria davidii $\times$ palibiniana K. Choi \& J. H. Pak, Plant Species Biology 16: 46, 2001" nom. invalid.

국명: 보현개별꽃 Bo-hyeon-gae-byeol-kkot.

Diagnosis: Pseudostellaria $\times$ bohyeonsanensis M. Kim \& H. Jo can be distinguished from its related taxa P. okamotoi var. longipedicellata f. longipedicellata and $P$. davidii by having sterile fruit, a long pedicel $(2.2-6.0 \mathrm{~cm})$, and stem recline to the ground after flowering.

Perennial herbs; rhizomatous with 1-3 aerial stem, root tubers fusiform, 1-4, 7-37 mm × 1-3 mm. Plant $30-46.3 \mathrm{~cm}$, erect when flowering, but lateral shoots are elongated and reclined on the ground, with 1-2 lines vertical rows of trichomes. Proximal leaves spatulate, apex acute, $0.7-1.7 \mathrm{~cm} \times 0.3-0.5 \mathrm{~cm}$; middle leaves oblong, oblanceolate, apex acute, cuspidate, $2.0-4.5 \mathrm{~cm}$ $\times 0.6-1.6 \mathrm{~cm}$; distal leaves opposite, ovate-lanceolate, ovate, oval, apex acute, cuspidate, $3.2-5.9 \mathrm{~cm} \times 1.7-3.7 \mathrm{~cm}$, with margin pubescent at base, petiole 3-8 mm long. Chasmogamic flowers 1-2, axillary or(and) terminal, pedicel $2.2-6.0 \mathrm{~mm}$ long, 1 line vertical rows of trichomes. Sepals 5, lanceolate, 4-6 mm $\times 1.1-1.6 \mathrm{~mm}$, with margin and midvein trichomes. Petals 5, obovate, apex shallow emarginate, $5.0-7.0 \mathrm{~mm} \times 2.5-3.3 \mathrm{~mm}$. Styles 2-3, 4.0-5.5 mm long. Stamens 10, 3.4-4.7 mm long; Anther purple-brown, $0.5-0.6 \mathrm{~mm}$ long. Cleistogamic flower absent or axillary, 0-3, pedicel 14-40 mm long. Seedless.

Flowering: Apr to May.

Distribution: Korea (Bohyeonsan Mt., Cheongsong-gun, Gyeongsangbuk-do).

Habitats: This species grows along the ridge line of Bohyeonsan Mt. in South Korea. 

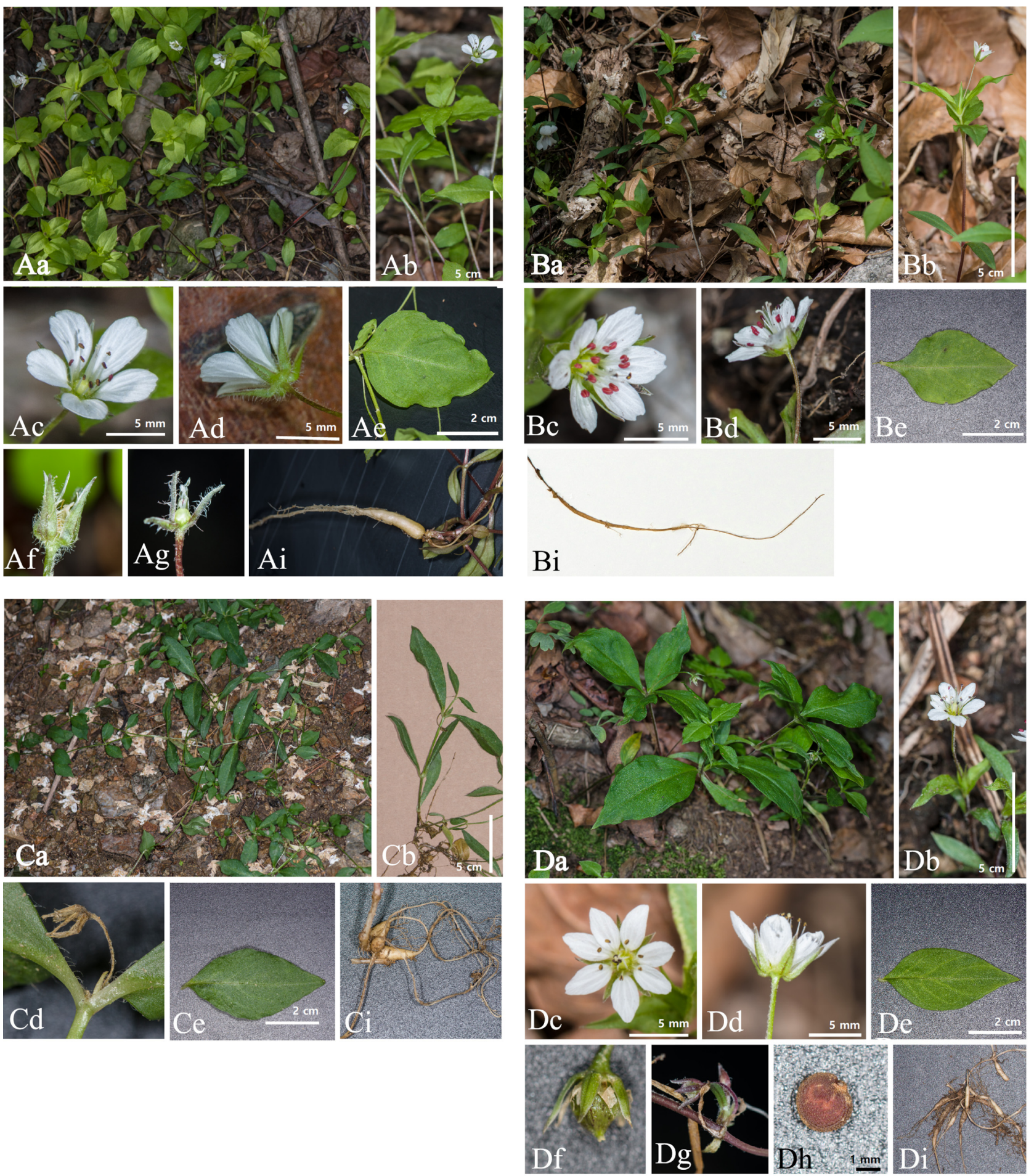

Fig. 10. Photographs of 4 Pseudostellaria hybrids in Korea. A. $P . \times$ bohyeonsanensis. B. $P . \times$ biseulsanensis. C. $P . \times$ seoraksanensis. D. $P . \times$ segeolsanensis. a. Habit. b. Inflorescence. c. Chasmogamic flower. d. Sepal \& pedicel. e. Leaf(above: distal leaf, below: middle leaf). f. Capsule. g. Cleistogamic flower. h. Seed. i. Tuber root.

괴경은 방추형으로 $1-4$ 개가 달리며, 길이는 7-37 mm이 고, 너비는 1-3 mm이다. 지상부 줄기는 1-3개로 괴경을 통 해 이웃하여 연결되어 있다. 식물체의 길이는 $30.0-$
$46.3 \mathrm{~cm}$ 이고 개화기에는 직립하나 덩굴성으로 되며, 줄기 의 털은 1-2줄이다. 하부 잎은 주걱형이고, 엽선은 예두이 고, 엽신 길이는 $0.7-1.7 \mathrm{~cm}$ 이고 너비는 $0.3-0.5 \mathrm{~cm}$ 이다. 중 

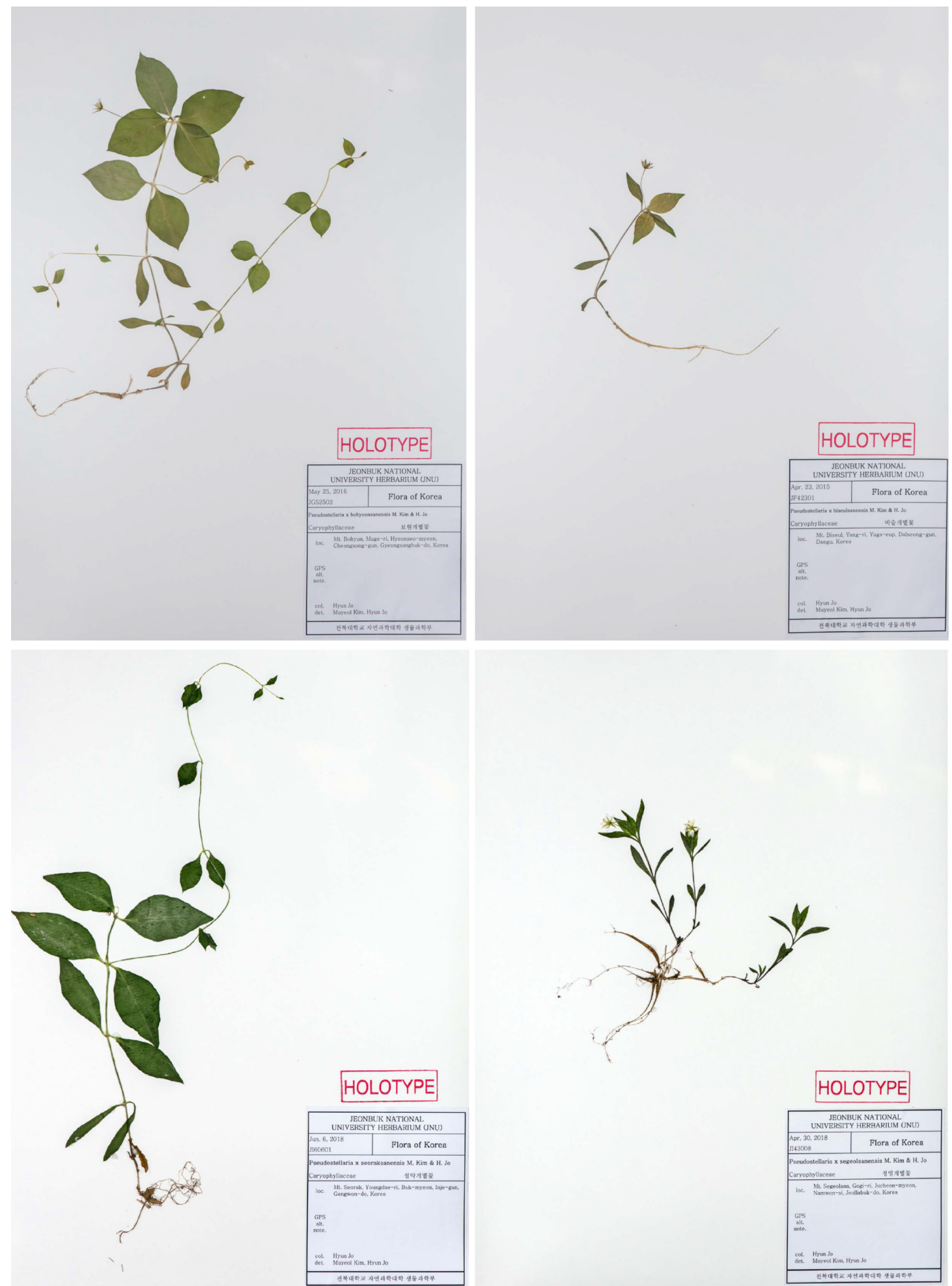

Fig. 11. Holotypes of 4 Pseudostellaria hybrids. A. P. $\times$ bohyeonsanensis. B. P. $\times$ biseulsanensis. C. . $\times$ seoraksanensis. D. P. $\times$ segeolsanensis.

부 잎은 장타원형, 도피침형이고, 엽선은 예두 또는 첨두 이고, 엽신의 길이는 $2.0-4.5 \mathrm{~cm}$, 너비는 $0.6-1.6 \mathrm{~cm}$ 이다.
상부 잎은 대생하고, 난상피침형, 난형, 광타원형이며, 엽 선은 예두 또는 첨두이다. 엽신의 길이는 $3.2-5.9 \mathrm{~cm}$, 너비 


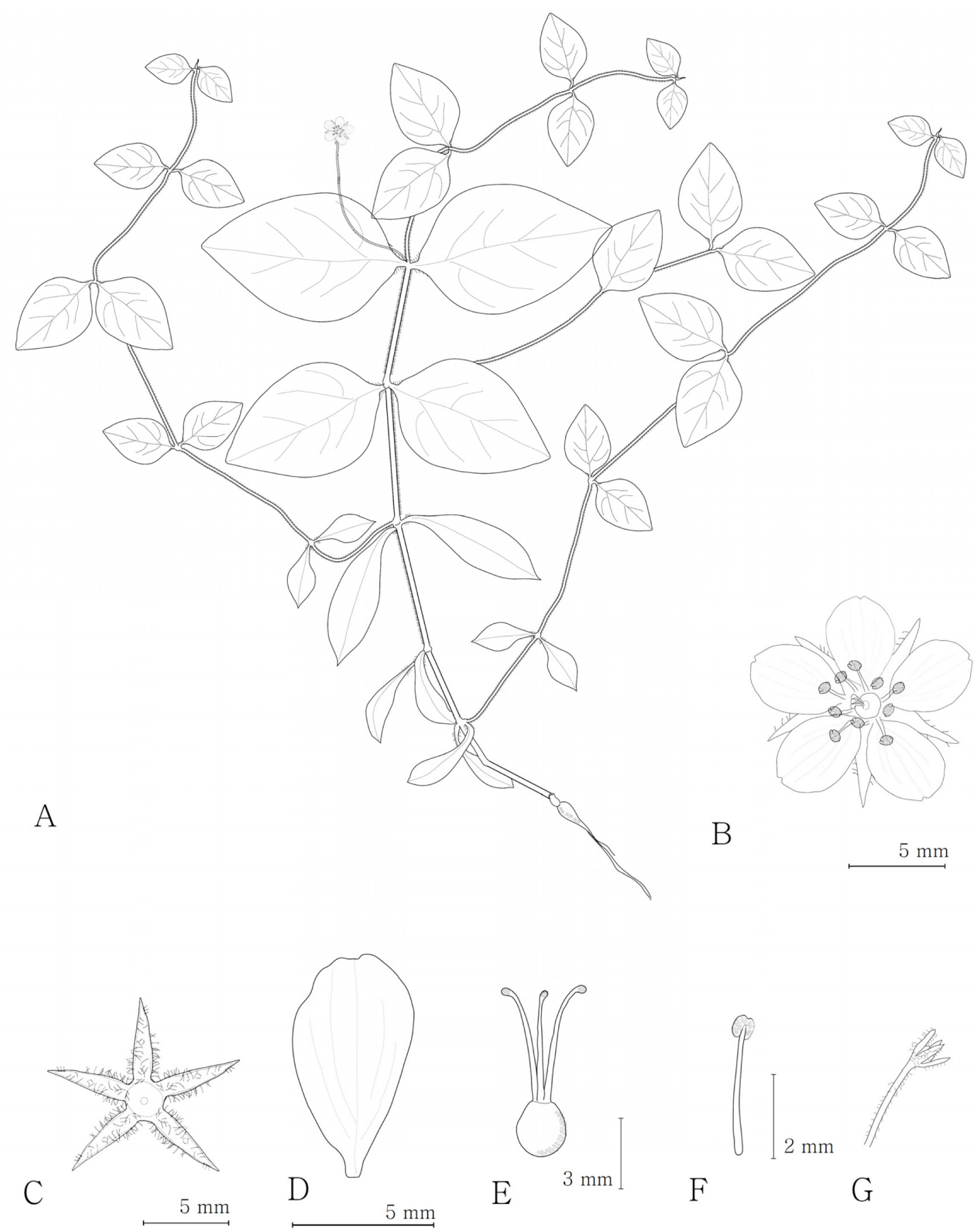

Fig. 12. Illustration of Pseudostellaria $\times$ bohyeonsanensis. A. Habit. B. Chasmogamic flower. C. Sepal. D. Petal. E. Pistil. F. Stamen. G. Cleistogamic flower.

는 1.7-3.7 cm로 잎 기부에 털이 있다. 엽병은 $3.0-8.0 \mathrm{~mm}$ 이다. 개화기는 4-5월이며, 꽃은 엽액과 정단부 또는 엽액 또는 정단부에서 1-2개 핀다. 소화경에 1줄의 털이 있고, 개화기 소화경 길이는 $2.2-6.0 \mathrm{~cm}$ 이다. 꽃받침은 5 개이고, 피침형으로 길이는 4-6 mm이고, 너비는 1.1-1.6 mm이며, 가장자리와 중륵에 털이 있다. 꽃잎은 5장이고, 도란형으
로 얕은 요두이며, 길이는 $5.0-7.0 \mathrm{~mm}$, 너비는 2.5-3.3 mm 이다. 암술대의 수는 2-3개이고, 길이는 4.0-5.5 mm이다. 수술의 수는 10 개이고, 길이는 3.4-4.7 mm이며, 약은 자갈 색으로 길이는 $0.5-0.6 \mathrm{~mm}$ 이다. 폐쇄화는 없거나 엽액에 0-3개 달리며, 폐쇄화 소화경의 길이는 $14-40 \mathrm{~mm}$ 이다. 종 자는 결실되지 않는다. 
국내분포: 경북(보현산).

생육지: 고지대 능선.

분류학적 검토: 보현개별꽃은 덩굴개별꽃과 큰개별꽃 의 교잡종으로 보고되었으나, 라틴 기재가 누락되어 정당 공표되지 않았다(Choi, 1999; Choi et al., 2001). 모종에 대한 인식을 반영하고 합법적인 이름을 부여하기 위해 새로 기 재하였다. Choi (1999)는 태백개별꽃을 큰개별꽃의 생태 형으로 보았으나 태백개별꽃을 큰개별꽃과는 다른 종으 로 보는 견해((Lee et al., 2012; Jo et al., 2014; Kim, 2017; Jo, 2019)에 따라, 태백개별꽃과 덩굴개별꽃 사이의 교잡종으 로 봐야 타당하며, 또한 보현산에는 큰개별꽃이 생육하지 않는 것으로 관찰되었고, 본 연구 기간 동안 덩굴개별꽃 과 태백개별꽃 혼생지역에서 교잡종으로 보고된 것과 같 은 특징을 보이는 개체를 확인하여 채집하였다(Appendix 1). 보현개별꽃은 꽃잎은 5 장이고 소화경에 털이 있으며, 개화 후 줄기가 덩굴성으로 된다는 점에서 덩굴개별꽃과 유사하나 종자 결실되지 않으며, 원줄기의 상부 잎과 덩 굴성 줄기의 잎이 이형이라는 점에서 동형(난형)인 덩굴 개별꽃과 구별된다.

10. Pseudostellaria $\times$ biseulsanensis M. Kim \& H. Jo, nothosp. nov. (Figs. 10B, 11B, 13).-TYPE: Korea. Daegu-si: Dalseong-gun, Biseulsan Mt., elev. 670 m, 23 Apr 2015. $H$. Jo, JF42301 (holotype, JNU; isotypes, JNU).

Hybrid parents: Pseudostellaria heterophylla $\times$ P. okamotoi var. longipedicellata

"Pseudostellaria heterophylla $\times$ palibiniana K. Choi \& J. H. Pak, Acta Phytotax. Geobot. 50: 169, 1999" nom. invalid.

국명: 비슬개별꽃 Bi-seul-gae-byeol-kkot.

Diagnosis: Pseudostellaria $\times$ biseulsanensis M. Kim \& H. Jo can be distinguished from its related taxa $P$. heterophylla $\mathrm{f}$. heterophylla and $P$. okamotoi var. longipedicellata $\mathrm{f}$. longipedicellata by having a solitary aerial stem, a chasmogamic flower at the stem terminal, shallow marginate or bitten petal apex, 1 row of trichomes on the pedicel, and sterile fruit.

Perennial herbs; rhizomatous with 1 aerial stem; root tubers slender, 1-2, 25-50 mm $\times 2 \mathrm{~mm}$. Plant $6.2-14.5 \mathrm{~cm}$, erect or basally decumbent, with 2 lines vertical rows of trichomes. Proximal leaves spatulate, apex acute, $0.5-1.0 \mathrm{~cm} \times 0.2-0.4$ $\mathrm{cm}$; middle leaves elliptic, oblanceolate, spatulate, apex acute, cuspidate, $2.0-3.4 \mathrm{~cm} \times 0.4-1.0 \mathrm{~cm}$; distal leaves subverticillate, lanceolate, ovate-lanceolate, ovate, oval, apex acute, cuspidate, $2.3-6.0 \mathrm{~cm} \times 1.0-3.4 \mathrm{~cm}$, with margin pubescent at base, petiole near sessile. Chasmogamic flowers terminal and solitary, pedicel $1.7-2.3 \mathrm{~mm}$ long, 1 line vertical rows of trichomes. Sepals 5-6, lanceolate, 3.8-5.2 $\mathrm{mm} \times 1.1-$ $1.5 \mathrm{~mm}$, with basal margin trichomes. Petals 5-6, obovate, apex shallow emarginate, bitten, $4.8-5.9 \mathrm{~mm} \times 2.1-2.7 \mathrm{~mm}$. Styles 3-4, 3.9-4.5 mm long. Stamens 10-12, 2.9-4.2 mm long; Anther purple-brown, $0.5-0.7 \mathrm{~mm}$. Seedless.

Flowering: Apr.

Distribution: Korea (Biseulsan Mt., Dalseong-gun, Daegu-si).

Habitats: This species grows along the road side of forests of Biseulsan Mt. in South Korea.

괴경은 가는 방추형으로 1-2개가 달리며, 길이는 25$50 \mathrm{~mm}$ 이고, 너비는 $2 \mathrm{~mm}$ 이다. 지상부 줄기는 1 개이다. 식 물체의 높이는 6.2-14.5 cm이고 직립하거나 기부에서 굽어 져 직립하며, 줄기의 털은 2줄이다. 하부 잎은 주걱형이고, 엽선은 예두이고, 엽신 길이는 $0.5-1.0 \mathrm{~cm}$ 이고 너비는 0.2$0.4 \mathrm{~cm}$ 이다. 중부 잎은 타원형, 도피침형, 주걱형이고, 엽선 은 예두 또는 첨두이고, 엽신의 길이는 $2.0-3.4 \mathrm{~cm}$, 너비는 0.4-1.0 cm이다. 상부 잎은 위윤생하고, 피침형, 난상피침형, 난형, 광타원형이며, 엽선은 예두 또는 첨두이다. 엽신의 길 이는 2.3-6.0 cm, 너비는 1.0-3.4 cm로 잎 기부에 털이 있다. 엽병은 거의 없다. 개화기는 4월이며, 꽃은 정단부에서 한 개 핀다. 소화경에는 1 줄의 털이 있고, 개화기 소화경 길이 는 $1.7-2.3 \mathrm{~cm}$ 이다. 꽃받침은 5-6개이고, 피침형으로 길이는 3.8-5.2 mm이고, 너비는 1.1-1.5 mm이며, 기부 가장자리에 털이 있다. 꽃잎은 5-6장이고, 도란형으로 얕은 요두, 결각 상이며, 길이는 4.8-5.9 mm, 너비는 2.1-2.7 mm이다. 암술대 의 수는 3-4개이고, 길이는 3.9-4.5 mm이다. 수술의 수는 10-12개이고, 길이는 2.9-4.2 mm이며, 약은 자갈색으로 길 이는 0.5-0.7 mm이다. 종자는 결실되지 않는다.

국내분포: 대구(비슬산), 경북(팔공산).

생육지: 산지 솦속 등산로 주변.

분류학적 검토: 비슬개별꽃은 개별꽃과 큰개별꽃의 교 잡종으로 보고되었으나, 라틴 기재가 누락되어 정당 공표 되지 않았다(Choi \& Pak, 1999; Choi, 1999). 모종에 대한 인 식을 반영하고 합법적인 이름을 부여하기 위해 새로 기재 하였다. Choi (1999)는 태백개별꽃을 큰개별꽃의 생태형 으로 보았으나 태백개별꽃을 큰개별꽃과는 다른 종으로 보는 견해(Lee et al., 2012; Jo et al., 2014; Kim, 2017; Jo, 2019)에 따라, 태백개별꽃과 개별꽃 사이의 교잡종으로 봐야 타당하다. 비슬개별꽃은 꽃잎은 얕은 요두 또는 결 각상이고, 소화경에 1줄의 털이 있고, 괴경수는 1-2개이 고 가늘고 긴 방추형이며, 종자 결실하지 않는다는 점에 서 태백개별꽃 또는 개별꽃과 구별되었다(Tables 1,2$)$.

11. Pseudostellaria $\times$ seoraksanensis $\mathrm{M}$. Kim \& H. Jo, nothosp. nov. (Figs. 10C, 11C, 14).-TYPE: Korea. Gangwondo: Inje-gun, Seoraksan Mt., elev. 490 m, 6 Jun 2018, H. Jo, JI60601 (holotype, JNU; isotypes, JNU, KH). 

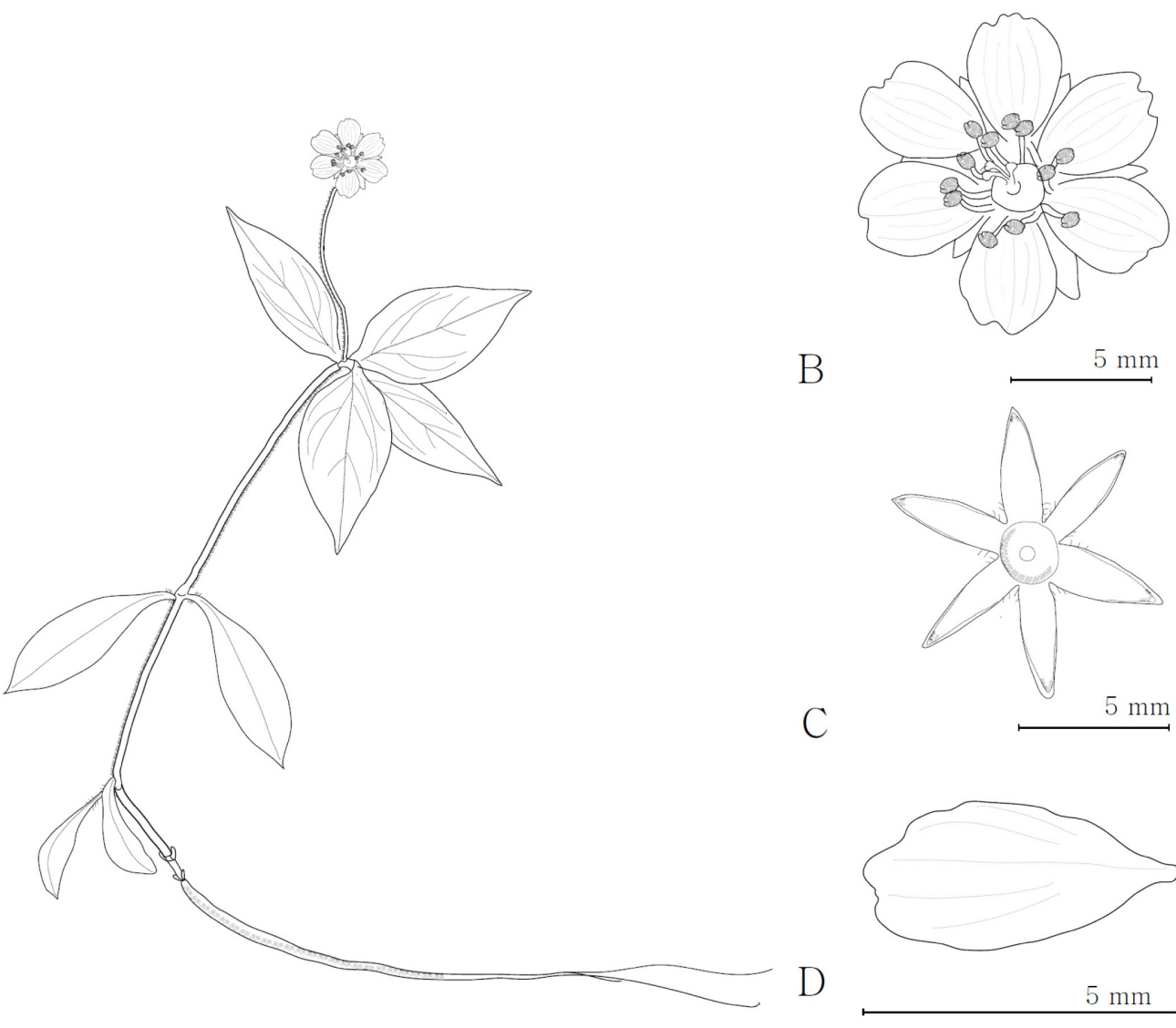

C

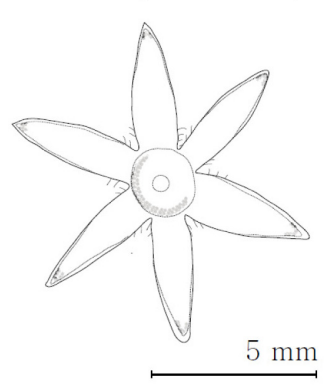

$\mathrm{D}$

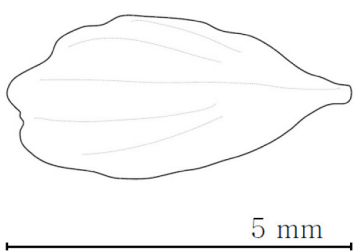

A

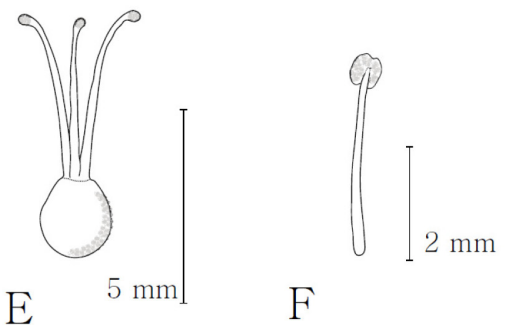

Fig. 13. Illustration of Pseudostellaria $\times$ biseulsanensis. A. Habit. B. Chasmogamic flower. C. Sepal. D. Petal. E. Pistil. F. Stamen.

Hybrid parents: Pseudostellaria davidii $\times$ P. palibiniana var. palibiniana

국명: 설악개별꽃 Seor-ak-gae-byeol-kkot (국명신칭).

Diagnosis: Pseudostellaria $\times$ seoraksanensis M. Kim \& H. Jo can be distinguished from its related taxa $P$. davidii and $P$. palibiniana var. palibiniana $\mathrm{f}$. palibiniana by having sterile fruit and a short pedicel $(1.1-1.8 \mathrm{~cm})$, and stem recline to the ground after flowering.

Perennial herbs; rhizomatous with 1-2 aerial stem, root tubers fusiform or napiform, 3-4, 6-18 $\mathrm{mm} \times 2-4 \mathrm{~mm}$. Plant $35.0-47.0 \mathrm{~cm}$, lateral shoots are elongated and reclined on the ground, with 1-2 lines vertical rows of trichomes. Proximal leaves spatulate, apex acute, $1.2-1.7 \mathrm{~cm} \times 0.4-0.5$ $\mathrm{cm}$; middle leaves oblong, oblanceolate, apex acute, 4.0-5.1 $\mathrm{cm} \times 0.7-1.8 \mathrm{~cm}$; distal leaves opposite, oblong, elliptic, 


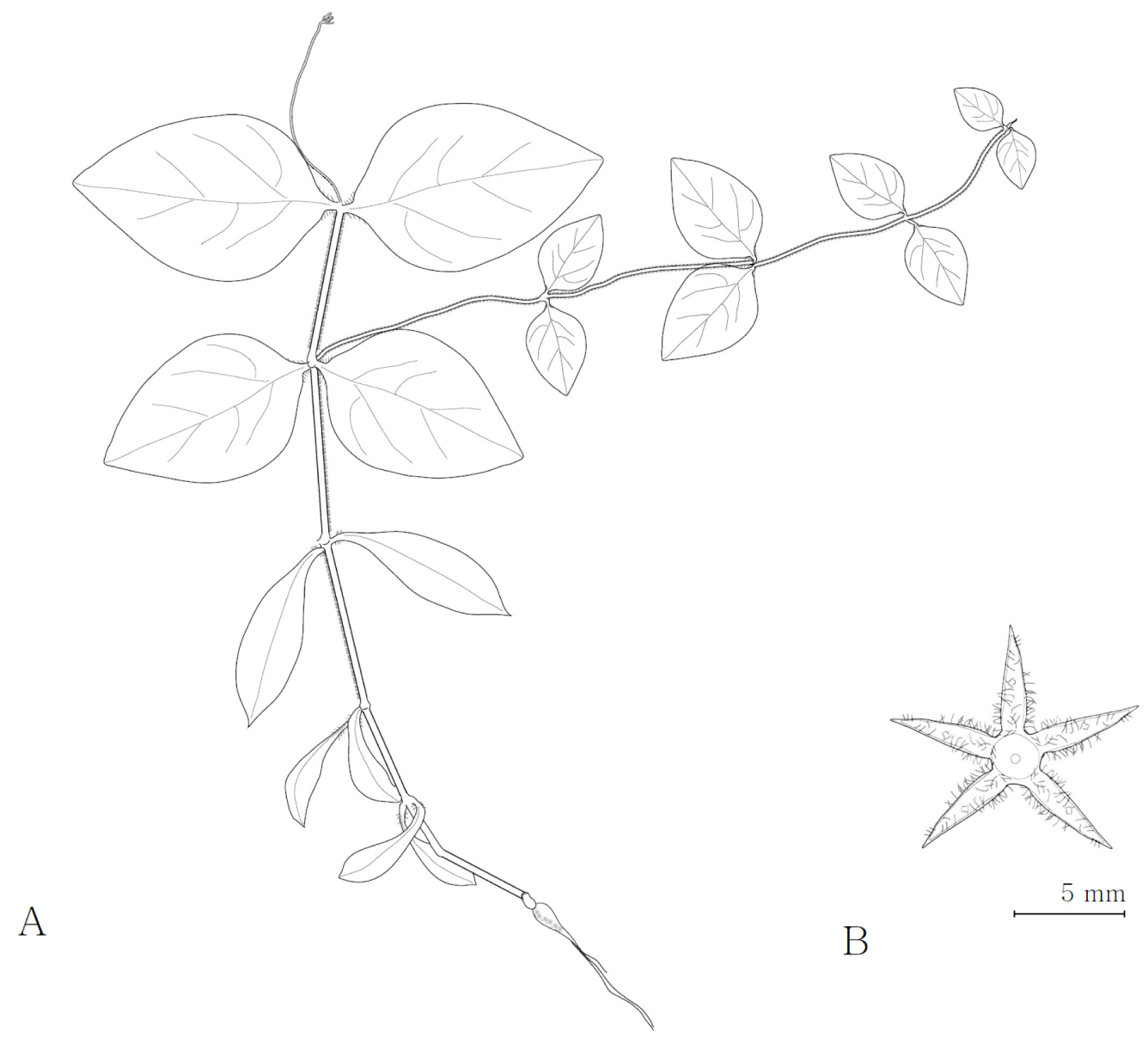

Fig. 14. Illustration of Pseudostellaria $\times$ seoraksanensis. A. Habit. B. Sepal.

lanceolate, ovate, oval, apex acute, cuspidate, $2.9-7.0 \mathrm{~cm} \times$ $1.2-3.0 \mathrm{~cm}$, with margin pubescent at base, petiole $2-5 \mathrm{~mm}$ long. Chasmogamic flowers $1-2$, axillary or(and) terminal, pedicel 1.1-1.8 cm long, 1 line vertical rows of trichomes. Sepals 5, lanceolate, with margin and midvein trichomes. Cleistogamic flower axillary on stem, $0-1$, pedicel $1 \mathrm{~mm}$ long. Seedless.

Flowering: May.

Distribution: Korea (Seoraksan Mt., Inje-gun, Gangwon-do).

Habitats: This species grows along the road side of forests of Seoraksan Mt. in South Korea.

괴경은 방추형 또는 순무형으로 3-4개가 달리며, 길이 는 6-18 $\mathrm{mm}$ 이고, 너비는 2-4 mm이다. 지상부 줄기는 1-2 개로 괴경을 통해 이웃하여 연결되어 있다. 식물체의 길 이는 35.0-47.0 cm이고 개화기에는 직립하나 덩굴성으로 되며, 줄기의 털은 1-2줄이다. 하부 잎은 주걱형이고, 엽 선은 예두이고, 엽신 길이는 $1.2-1.7 \mathrm{~cm}$ 이고 너비는 0.4$0.5 \mathrm{~cm}$ 이다. 중부 잎은 장타원형, 도피침형이고, 엽선은
예두이고, 엽신의 길이는 $4.0-5.1 \mathrm{~cm}$, 너비는 $0.7-1.8 \mathrm{~cm}$ 이 다. 상부 잎은 대생하고, 장타원형, 타원형, 피침형, 난형, 광타원형이며, 엽선은 예두 또는 첨두이다. 엽신의 길이 는 2.9-7.0 cm, 너비는 $1.2-3.0 \mathrm{~cm}$ 로 잎 기부에 털이 있다. 엽병은 2-5 mm이다. 개화기는 5월이며, 꽃은 엽액과 정 단부 또는 엽액 또는 정단부에서 1-2개 핀다. 소화경에는 1 줄의 털이 있고, 개화기 소화경 길이는 $1.1-1.8 \mathrm{~cm}$ 이다. 꽃받침은 5 개이고, 피침형이다. 폐쇄화는 엽액에 0-1개 달리며, 폐쇄화 소화경의 길이는 $1 \mathrm{~mm}$ 이다. 종자는 결실 되지 않는다.

국내분포: 강원(설악산).

생육지: 산지 솦속 등산로 주변.

분류학적 검토: 설악개별꽃은 덩굴개별꽃과 큰개별꽃 의 혼생 지역에서 두 분류군의 중간형태의 특징을 보이는 것으로 나타났다. 설악개별꽃은 꽃받침이 5 개이고, 소화 경에 털이 있으며, 개화 후에 덩굴성으로 변한다는 점에 서 덩굴개별꽃과 유사하나, 종자 결실하지 않으며, 원줄 기 상부 잎과 곁가지의 잎이 서로 다르다는 점에서 뚜렷 하게 구별되었다. 큰개별꽃과 태백개별꽃이 소화경 길이 


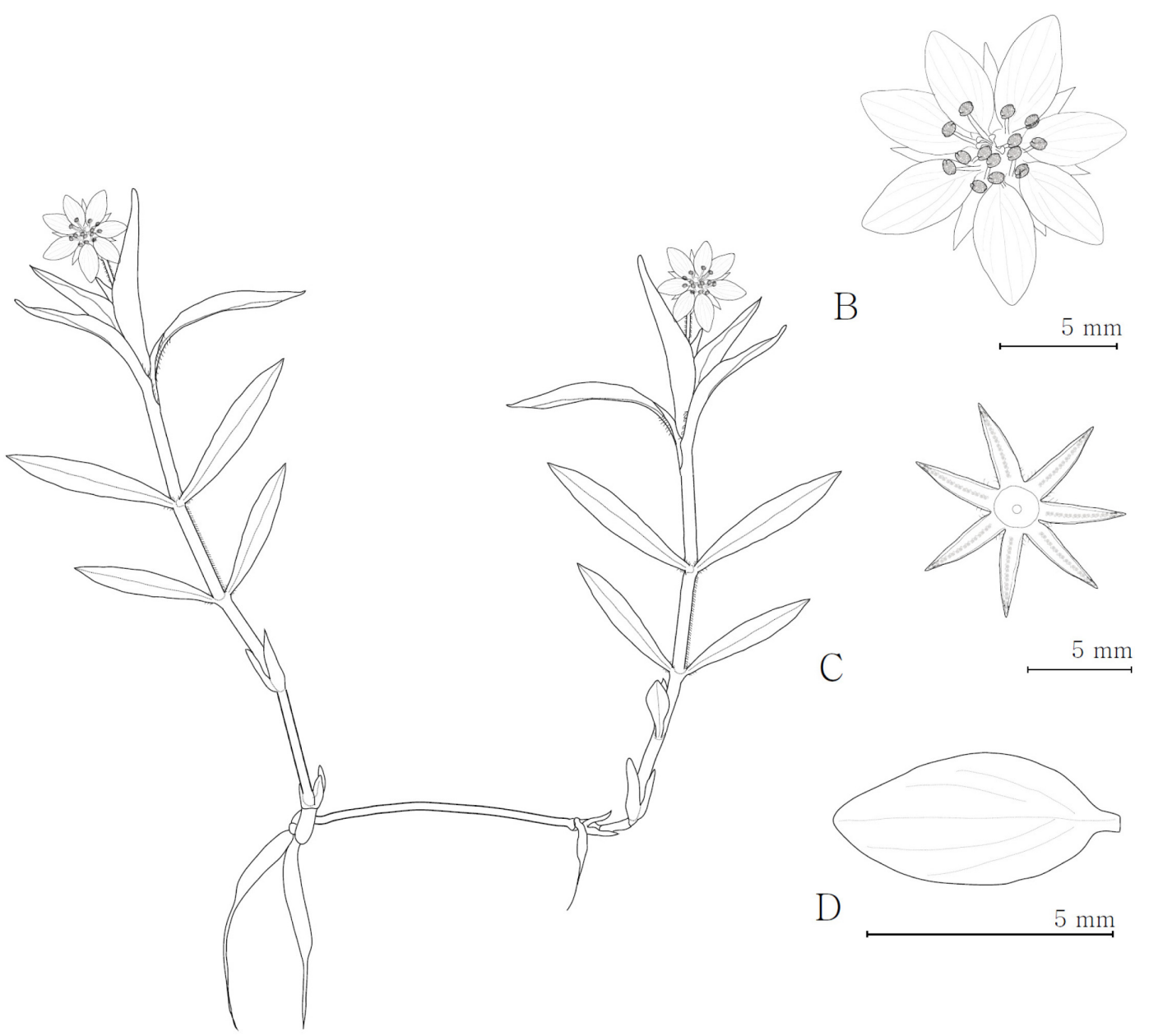

A
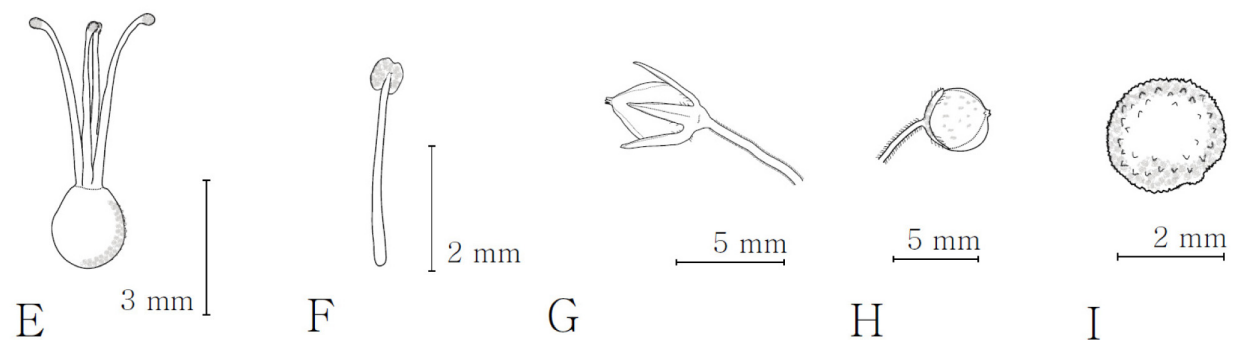

$2 \mathrm{~mm}$

E

F

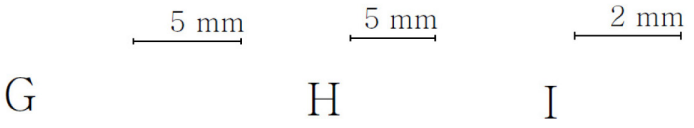

Fig. 15. Illustration of Pseudostellaria $\times$ segeolsanensis. A. Habit. B. Chasmogamic flower. C. Sepal. D. Petal. E. Pistil. F. Stamen. G. Capsule. H. Cleistogamic flower. I. Seed.

에서 뚜렷한 차이를 보인 것과 마찬가지로, 중간형을 보 이는 교잡종인 설악개별꽃과 보현개별꽃은 소화경 길이 에서 차이를 보였다. 소화경 길이는 설악개별꽃이 1.1 (1.4) $1.8 \mathrm{~cm}$ 이고, 보현개별꽃은 2.2 (3.9) $6.0 \mathrm{~cm}$ 로 나타났 고, 폐쇄화 소화경의 길이는 설악개별꽃이 $1 \mathrm{~mm}$ 이고, 보 현개별꽃은 14 (26.4) $40 \mathrm{~mm}$ 로 나타났다(Table 2).
12. Pseudostellaria $\times$ segeolsanensis $\mathrm{M}$. Kim \& H. Jo, nothosp. nov. (Figs. 10D, 11D, 15).-TYPE: Korea. Jeollabukdo: Namwon-si, Segeolsan Mt., elev. 1,200 m, 30 Apr 2018, H. Jo, JI43008 (holotype, JNU; isotypes, JNU, KH).

Hybrid parents: Pseudostellaria palibiniana var. palibiniana 


\section{$\times$ P. okamotoi var. okamotoi}

국명: 정영개별꽃 Jeong-yeong-gae-byeol-kkot (국명신칭).

Diagnosis: Pseudostellaria $\times$ segeolsanensis M. Kim \& H. Jo can be distinguished from its related taxa P. palibiniana var. palibiniana f. palibiniana and $P$. okamotoi var. okamotoi by having numerous aerial stems, a chasmogamic flower at the stem terminal, 1-2 rows of trichomes on the pedicel, and fertile fruit.

Perennial herbs; rhizomatous with 1-7 aerial stem, root tubers fusiform, $1-10,5-26 \mathrm{~mm} \times 2-3 \mathrm{~mm}$. Plant $7.8-14.7 \mathrm{~cm}$, erect or basally decumbent, with 1-2 lines vertical rows of trichomes. Proximal leaves spatulate, apex acute, $0.4-1.2 \mathrm{~cm}$ $\times 0.2-0.3 \mathrm{~cm}$; middle leaves oblong, oblanceolate, apex acute, cuspidate, acuminate, $2.3-4.8 \mathrm{~cm} \times 0.3-0.8 \mathrm{~cm}$; distal leaves subverticillate, oblong, lanceolate, ovate-lanceolate, ovate, apex acute, cuspidate, acuminate, $3.0-7.7 \mathrm{~cm} \times 0.6-3.7 \mathrm{~cm}$, with margin pubescent at base, petiole near sessile. Chasmogamic flowers terminal and solitary, pedicel $1.2-3.1 \mathrm{~cm}$ long, 1-2 lines vertical rows of trichomes, fruit pedicel $2.3-3.4 \mathrm{~cm}$ long. Sepals 5-7, lanceolate, $4.0-5.5 \mathrm{~mm} \times 0.8-1.3 \mathrm{~mm}$, with basal margin trichomes. Petals 5-7, elliptic, narrow ovate, apex acute, 5.1-6.2 mm × 2.5-3.2 mm. Styles 3-4, 2.6-3.8 mm long. Stamens 10-14, 3.8-4.2 mm long; Anther purple-brown, 0.5$0.6 \mathrm{~mm}$ long. Cleistogamic flower axillary on stem and terminal, 4-7, pedicel 7-14 mm long. Capsules with 1-4 seeds: Seed reniform or subglobose, brown, with mammillate, 2.3$2.6 \mathrm{~mm} \times 2.1-2.4 \mathrm{~mm}$.

Flowering: Apr to May.

Fruiting: Jun.

Distribution: Korea (Segeolsan Mt., Namwon-si, Jeollabuk-do).

Habitats: This species grows along the road side of forests of Segeolsan Mt. in South Korea.

괴경은 방추형으로 1-10개가 달리며, 길이는 5-26 mm 이고, 너비는 2-3 mm이다. 지상부 줄기는 1-7개로 괴경을 통해 이웃하여 연결되어 있다. 식물체의 높이는 7.8$14.7 \mathrm{~cm}$ 이고 직립하거나 기부에서 굽어져 직립하며, 줄기 의 털은 1-2줄이다. 하부 잎은 주걱형이고, 엽선은 예두이 고, 엽신 길이는 $0.4-1.2 \mathrm{~cm}$ 이고 너비는 $0.2-0.3 \mathrm{~cm}$ 이다. 중 부 잎은 장타원형, 도피침형이고, 엽선은 예두, 첨두, 점첨 두이고, 엽신의 길이는 $2.3-4.8 \mathrm{~cm}$, 너비는 $0.3-0.8 \mathrm{~cm}$ 이다. 상부 잎은 위윤생하고, 장타원형, 피침형, 난상피침형, 난 형이며, 엽선은 예두, 첨두, 점첨두이다. 엽신의 길이는 3.0-7.7 cm, 너비는 0.6-3.7 cm로 잎 기부에 털이 있다. 엽병 은 거의 없다. 개화기는 4-5월이며, 꽃은 정단부에서 한개 핀다. 소화경에 1-2줄의 털이 있고, 개화기 소화경 길이는 $1.2-3.1 \mathrm{~cm}$ 이고, 결실기 소화경의 길이는 $2.3-3.4 \mathrm{~cm}$ 이다.
꽃받침은 5-7개이고, 피침형으로 길이는 4.0-5.5 mm이고, 너비는 0.8-1.3 mm이며, 기부 가장자리에 털이 있다. 꽃잎 은 5-7장이고, 타원형 또는 좁은 난형으로 예두이며, 길이 는 5.1-6.2 mm, 너비는 2.5-3.2 mm이다. 암술대의 수는 3-4 개이고, 길이는 2.6-3.8 mm이다. 수술의 수는 10-14개이고, 길이는 3.8-4.2 mm이며, 약은 자갈색으로 길이는 0.5$0.6 \mathrm{~mm}$ 이다. 폐쇄화는 엽액과 정단부에 4-7개 달리며, 폐 쇄화 소화경의 길이는 7-14 mm이다. 열매는 삭과이며 6 월 결실하며, 1-4개의 신장형 또는 구형 종자가 들어있다. 종자 표면에 유두상의 돌기가 있으며, 길이는 2.3-2.6 mm, 너비는 2.1-2.4 mm이다.

국내분포: 전북(세걸산).

생육지: 산지 솦속 등산로 주변.

분류학적 검토: 세걸산의 큰개별꽃은 저지대에서부터 해발 $1,200 \mathrm{~m}$ 에 이르는 구간에 분포하고, 지리산개별꽃이 분포하기 시작하는 해발 $1,200 \mathrm{~m}$ 지점에서 두 분류군의 중 간형인 정영개별꽃을 발견하여 새로 기재하였다. 정영개 별꽃은 괴경의 형태가 방추형이고, 소화경에 털이 1-2줄 난다는 점에서 지리산개별꽃과 유사하나, 꽃잎의 수가 많 고, 소화경의 길이가 짧고 줄기 기부로 쳐지지 않는다는 점에서 큰개별꽃과 비슷한 특징을 보였다. 또한 결실기 소화경 길이, 폐쇄화 소화경 길이, 암술대의 수는 지리산 개별꽃과 큰개별꽃의 중간형을 보였으며, 삭과의 종자는 1-4개로 두 분류군 보다 적어 차이를 보였다(Tables 1,2 ).

\section{고 찰}

한국에 분포하는 개별꽃속(Pseudostellaria) 19분류군에 대해 형태학적 연구 결과 잎의 털, 꽃받침의 털, 소화경의 털, 꽃잎의 수와 정단부 형태, 잎의 형태, 소화경의 길이와 굴곡 여부, 괴경의 형태, 지하경의 유무, 덩굴성 여부, 종자 결실 여부 등이 유용한 식별 형질로 조사되었다.

가는잎개별꽃 $(P$ sylvatica)은 잎이 침형 또는 선상 피침 형이라는 점이 특징인 분류군으로, 백두산 일대에는 흔히 분포하지만 설악산 일대에만 드물게 발견되어 보호가 필 요한 종이다. 긴개별꽃(P. japonica)은 한때 숲개별꽃 $(P$. setulosa)으로 잘못 인식되어 국내에는 자생하지 않는 것 으로 알려졌으나, 강원도 일대와 경북 칠곡에서 발견되었 다. 덕유산 백련사 주변에서 긴개별꽃의 채집 기록이 있 으나 본 연구 기간 동안 발견하지 못하였다. 덩굴개별꽃 (P. davidii)은 엽액에서 꽃이 피고 정단부 길이 생장과 곁 가지 발생에 의해 개화기 이후 직립하지 못하고 덩굴성으 로 땅위를 기는 특징이 있다. 괴경의 형태는 방추형과 순 무형으로 나타났으며, 순무형 중에서 끝이 뭉뚝한 것은 구형으로 보이는 변이가 관찰되므로, 덩이뿌리개별꽃 $(P$. bulbosa)을 덩굴개별꽃의 변이로 보는 견해(Ohwi, 1937)를 따랐다. 태백개별꽃은 결실기에 소화경이 줄기 기부까지 길어지는 점과 폐쇄화 소화경의 길이, 생육 환경 및 해발 
고도 등이 지리산개별꽃과 유사하나, 꽃잎의 수와 괴경의 모양, 소화경의 털에서 차이를 보여 지리산개별꽃의 변종 (P. okamotoi var. longipedicellata)으로 보는 견해를 따랐다. 큰개별꽃(P. palibiniana var. palibiniana)은 가는 방추형의 괴경이 특징(Mizushima, 1965)이나 거제, 부산, 제주 개체 는 짧고 굵은 형태의 방추형 개체가 널리 분포하여, 일반 적인 큰개별꽃의 괴경과 차이를 보였다. 숲개별꽃은 지하 경을 길게 뻗어 새로운 개체를 발생시키므로 이웃하는 개 체와 잎과 잎이 맞닿는 정도의 피도를 보이며 군락을 형 성하곤 한다. 지하경 중간에서 괴경이 형성되며, 염주형 이외에도 구형, 타원형, 곤봉형 등 다양한 형태의 괴경이 관찰되었으나 폐쇄화는 형성되지 않는다. 개별꽃 $(P$. heterophylla f. heterophylla)은 꽃잎 정단부가 요두이고 괴 경이 1 개 또는 드물게 2 개라는 점이 인식형질로 알려져 왔으나, 꽃잎 정단부 형태의 변이와 관찰시점에 따른 괴 경의 수에 차이를 보여 인식형질로 적용하기 어려운 것으 로 나타났다. 소화경 전체에 털이 있고, 괴경과 연결된 지 상부 개체가 하나이고, 괴경이 다발을 이루지 않는다는 점이 주된 특징이다.

개별꽃속의 교잡종에 대한 연구는 Choi (1999), Choi and Pak (1999), Choi et al. (2001)에 의해 이루어졌으며, 두 종의 혼생지역에서 중간형의 특징을 보이는 것으로 나타났다. 보현개별꽃 $(P \times$ bohyeonsanensis $)$ 은 덩굴개별꽃과 태백개 별꽃 혼생 지역에서 발견되며, 종자가 결실되지 않고, 원 줄기의 상부 잎과 곁가지의 잎의 형태가 서로 달라 구별 된다. 설악개별꽃 $(P . \times$ seoraksanensis $)$ 은 덩굴개별꽃과 큰 개별꽃의 혼생 지역에서 관찰되었으며, 종자가 결실되지 않고, 원줄기의 상부 잎과 곁가지의 잎의 형태가 서로 다 르며, 소화경길이에서 보현개별꽃과 구별되었다. 비슬개 별꽃 $(P . \times$ biseulsanensis $)$ 은 개별꽃과 태백개별꽃 혼생지 역에서 발견되며, 괴경과 연결된 지상부 개체가 하나이고 정단부에 꽃이 한개만 피며, 꽃잎은 요두 또는 결각상이 며, 소화경에 1줄의 털이 있고, 종자 결실되지 않는 특징이 있다. 정영개별꽃은 $(P . \times$ segeolsanensis $)$ 은 지리산개별꽃 과 큰개별꽃의 중간형으로 소화경의 길이는 두 분류군의 중간이고 소화경이 줄기 기부로 처지지 않으면서 1-2 줄 의 털이 있어 구별되었다.

개별꽃속의 다양한 종간에 이루어지는 교잡종을 관찰 한 결과 해발고도, 생육환경, 개화시기 등이 중첩되면 교 잡종 출현을 기대할 수 있고, 일정한 공간을 점유하는 군 락과 개체수가 충분하면 발견 가능성이 높아지고, 뚜렷한 형태상의 차이를 보이는 두 분류군 사이의 교잡이면 중간 형을 인식하는데 어려움이 줄어듬을 알게되었다. 본 연구 기간 중 운악산 일대에서 개별꽃과 큰개별꽃의 혼생 지역, 태백산과 소백산에서 덩굴개별꽃과 태백개별꽃의 혼생 지역, 광양 백운산에서 지리산개별꽃과 큰개별꽃의 혼생 지역, 지리산 일대에서 지리산개별꽃과 혼생하는 태백개 별꽃이나 덩굴개별꽃의 자연군락을 추가로 발견하였으
나 교잡종을 발견하지 못해 흔하게 종간 교잡종이 이루어 지지 않음 알게 되었다. 2014년부터 2018년까지 한국산 개 별꽃속에 대한 분류학적 연구를 종합적으로 수행한 결과, 한국산 개별꽃속은 8 종 4 교잡종 2 변종 5 품종으로 확인되 었다.

ORCID: Hyun JO https://orcid.org/0000-0003-4599-2835; Muyeol KIM https://orcid.org/0000-0003-4518-0773

\section{Acknowledgments}

We are deeply indebted to two anonymous reviewers for their critical reviews of the manuscript.

\section{Conflict of Interest}

The authors declare that there are no conflicts of interest.

\section{Literature Cited}

Choi, K. 1999. Biosystematic study of Pseudostellaria Pax (Caryophyllaceae). PhD disseration, Gyeongbuk National University, Daegu, Korea. 128 pp.

Choi, K. 2007. Pseudostellaria Pax. In The Genera of Vascular Plants of Korea. Park, C.-W. (ed.), Academy Publishing Co., Seoul. Pp. 317-318.

Choi, K., J. S. Kim and J.-H. Pak. 2001. Natural hybridization between Pseudostellaria davidii and Pseudostellaria palibiniana (Caryophyllaceae). Plant Species Biology 16: 39-47.

Choi, K and J.-H. Pak. 1999. A natural hybrid between Pseudostellaria heterophylla and P. palibiniana (Caryophyllaceae). Acta Phytotaxonomica et Geobotanica 50: 161-171.

Chung, T. H., B. S. To, D. B. Lee and H. J. Lee. 1937. Nomina Plantarum Koreanum. Chosen Natural History Institute, Seoul. P. 60.

Jo, H. 2019. Taxonomy, ecology and conservation biology of Pseudostellaria Pax in Korea. PhD dissertation, Chonbuk National University, Jeonju, Korea, 194 pp.

Jo, H., C. Shin and M. Kim. 2014. A new species of Pseudostellaria (Caryophyllaceae): P. baekdusanensis M. Kim. Korean Journal of Plant Taxonomy 44: 171-174.

Kim, M. 2017. Korean Endemic Plants. Haejin Media Co., Seoul. Pp. 120-123. (in Korean)

Kim, Y.-C., H.-H. Chae, S.-H. Oh, S.-H. Choi, M.-P. Hong, G.-H. Nam, J.-Y. Choi, H.-S. Choi and K.-S. Lee. 2015. Floristic characteristics of vascular plants and first distributional report of Pseudostellaria baekdusanensis M. Kim in Yongneup wetland protected area. Korean Journal of Environment and Ecol- 
ogy 29: 132-144.

Lee, S. P. 2013. Endemic Species of Korea. DoHyeon, Seoul. Pp. 170-171. (in Korean)

Lee, S., K.-I. Heo and S.-C. Kim. 2012. A new species of Pseudostellaria (Caryophyllaceae) from Korea. Novon 22: 25-31.

Lee, T. B. 1985. Illustrated Flora of Korea. Hyangmunsa, Seoul, 990 pp. (in Korean)

Lee, W. C. 1996a. Coloured Standard Illustrations of Korean Plants. Academy Publishing Co., Seoul, 855 pp. (in Korean)

Lee, W. C. 1996b. Lineamenta Florae Koreae. Academy Publishing Co., Seoul. P. 264. (in Korean).

Lee, Y. N. 1998. Flora of Korea. Kyohak Publishing Co., Seoul, 1237 pp. (in Korean)

Lu, D. and R. K. Rabeler. 2001. Pseudostellaria L. In Flora of
China. Vol. VI. Wu, Z.-Y. and P. H. Raven (eds.), Science Press, Beijing and Missouri Botanical Garden Press, St. Louis, MO. Pp. 7-10.

Mizushima, M. 1965. Critical studies on Japanese plants, 11: the genus Pseudostellaria Pax in Japan. Bulletin of the Botanical Survey of India 7: 62-72.

Ohwi, J. 1937. A revision of the genus Pseudostellaria. Japanese Journal of Botany: Transactions and Abstracts, 9: 95-105.

Park, M. K. 1974. Keys to the Herbaceous plants in Korea (Dicotyledoneae). Jeongeum, Seoul. 135 pp. (in Korean)

Song, J.-H., J.-M. Kim, M.-K. Ok and S.-P. Hong. 2015. Comparative seed morphology of the tribe Alsineae (Caryophyllaceae) in Korea and its taxonomic implications. Korean Journal of Plant Taxonomy 45: 369-379.

\title{
한국산 개별꽃속의 분류학적 연구
}

\author{
조현 · 김무열* \\ 전북대학교 자연과학대학 생명과학과
}

\begin{abstract}
적 요: 본 연구는 한국에 분포하는 개별꽃속의 종간 유연관계를 형태학적인 측면에서 재검토하기 위해 수 행되었다. 보현개별꽃 $($ Pseudostellaria $\times$ bohyeonsanensis $)$ 과 설악개별꽃 $(P . \times$ seoraksanensis $)$ 은 꽃받침 가장자 리와 중륵에 털이 있고 꽃잎은 5 장이며 개화기 이후 줄기가 덩굴성으로 되는 특징을 덩굴개별꽃( $P$. davidii) 과 공유하나, 보현개별꽃은 소화경이 길고, 설악개별꽃은 소화경의 길이가 짧아 구별되며 둘다 종자 결실을 못한다. 태백개별꽃(P. okamotoi var. longipedicellata)은 결실기 소화경의 길이와 줄기 기부까지 굽는 특징, 폐 쇄 소화경의 길이가 길다는 점에서 지리산개별꽃과 유사하나 괴경이 가는 방추형이고, 소화경에 털이 없고, 꽃잎이 5-9장이라는 점에서 구별된다. 가거개별꽃(P. palibiniana var. gageodoensis)은 꽃의 수와 위치, 꽃잎의 수, 소화경의 길이 등에서 큰개별꽃과 유사하나 소화경에 1-2줄의 털이 있고, 꽃받침 길이와 너비, 꽃잎의 길 이와 너비가 더 크고, 개화기에 줄기 기부에서 가지가 분지되는 특징을 보인다. 비슬개별꽃 $(P . \times$ biseulsanensis)은 태백개별꽃과 개별꽃의 중간형으로 괴경과 연결된 지상부 개체가 하나이고 정단부에 꽃이 한개만 피며, 꽃잎은 요두 또는 결각상이며, 소화경에 1 줄의 털이 있고, 종자가 결실되지 않는다. 정영개별꽃 $(P . \times$ segeolsanensis $)$ 은 지리산개별꽃과 큰개별꽃의 중간형으로 괴경과 연결된 지상부 개체가 다수이고, 정단 부에 꽃이 한개 피며, 소화경에 털이 1-2줄 있고, 종자 결실된다는 점에서 비슬개별꽃과 구별된다. 따라서 한 국산 개별꽃속 식물은 이번 연구를 통해 8종 4교잡종 2변종 5 품종으로 정리되었다.
\end{abstract}

주요어: 개별꽃속, 분류, 석죽과, 신분류군

Appendix 1. Examined specimens of Pseudostellaria species in Korea.

Pseudostellaria sylvatica (Maxim.) Pax

KOREA. Gangwon-do: Inje-gun, 25 May 2015, H. Jo, JF52501-JF52508 (JNU); 23 Jun 2015, H. Jo, JF62301 (JNU); 5 Jun 2018, H. Jo, JI60501 (JNU); 7 Jul 1996, J. O. Hyun et al., 20060910 (KH); Sokcho-si, 5 Jun 2018, H. Jo, JI60502 (JNU); 20 May 2012, J. S. Young et al., P126824 (KH). DPRK. Pyeonganbuk-do: 14 Jun 1982, anonymous, s.n. (KH); Hamgyeongbuk-do: 
14 Jul 1972, anonymous, s.n. (KH); 27 Jun 1994, anonymous, s.n. (KH). CHINA. Gillim: 13 Aug 2015, H. Jo, JF81316-JF81317 (JNU); 15 Jun 2018, H. Jo, JI61501 (JNU); 15 Jun 2018, H. Jo, JI61601-JI61602 (JNU); 24 May 2010, M. Kim, s.n. (JNU); 20 May 2014, M. Kim, s.n. (JNU); 13 May 2009, D. K. Lee, 2010-0422 (KH); 1 Sep 2006, B. U. Oh, Gillim22-060901-010 (KH); 16 Jun 1986, Y. H. Jin \& Wei Cao, NAPI 2013-0774 (KH); 28 Jun 2011, J. O. Hyun et al., NAPI 4052 (KH); 13 May 2009, D. K. Lee, 2009-0122 (KH); 18 May 2009, D. K. Lee, 2009-0178 (KH); 12 Jun 2004, E. S. Jeon, ESJeon41130 (KH); 10 Jul 2004, Y. H. Ahn, s.n. (KH).

\section{Pseudostellaria japonica (Korsh.) Pax}

KOREA. Gangwon-do: Inje-gun, 29 Apr 2015, H. Jo, JF42924-JF42925 (JNU); 18 Jun 2004, J. M. Chang \& M. H. Park, 4060142 (KH); Pyeongchang-gun, 4 May 2014, H. Jo, JE50431 (JNU); 14 Jun 2014, H. Jo, JE61430 (JNU); 14 Jun $2014, H$. Jo, JE61431-JE61438 (JNU); 29 Apr 2015, H. Jo, JF42926-JF42927 (JNU); 4 Jun 2018, H. Jo, JI60415-JI60417 (JNU); 23 Jun 2015, H. Jo, JF62309 (JNU); 9 May 2017, H. Jo, JH50904-JH50906 (JNU); 4 Jun 2018, H. Jo, JI60416-JI60417 (JNU); 10 Jun 2011, S. H. Park, ParkSH111374 (KH); 4 Jun 2011, J. D. Lee, PWK-010 (KH); 22 May 2012, J. C. Yang et al., L120257 (KH); 16 Apr 2011, J. D. Lee, PWK-054 (KH); 6 Aug 2011, J. S. Lee, PWK-005 (KH); 20 May 2011, Y. C. Kim, KYC0612 (KH); 22 May 2012, J. C. Yang et al., L120355 (KH); 22 May 2011, Y. C. Kim, KYC1872 (KH); 10 Jun 2011, S. H. Park, ParkSH111331 (KH); Wonju-si, 7 Jun 2018, H. Jo, JI60720-JI60724 (JNU); Hongcheon-gun, 23 May 2011, Y. W. Han, PWK-198 (KH); Hoengseung-gun, 17 Apr 2011, J. D. Lee, PWK-007 (KH); 4 May 2009, S. C. Ko, HNHM-2009-0041 (KH); 4 May 2009, S. C. Ko, HNHM-2009-0042 (KH); 4 May 2009, S. C. Ko \& D. C. Son, HNHM0002 (KH); 15 May 2004, K. Heo \& K. T. Yeo, K. Heo 1671 (KH); 24 May 2011, J. C. Yang et al., HS110242 (KH). Jeollabuk-do: Muju-gun, 5 Jun 2005, H. J. Kim, Choi-K-016 (KH); 5 Jun 2005, H. J. Kim, Choi-K-021 (KH). Gyeongsangbuk-do: Yeongju-si, 8 Jun 2018, H. Jo, JI60801-JI60806 (JNU); Chilgok-gun, 7 May 2015, H. Jo, JF50728-JF50734 (JNU); 22 Jun 2015, H. Jo, JF62201-JF62202 (JNU); 29 May 2018, H. Jo, JI52920 (JNU); Gunwi-gun, 14 May 2013, S. Y. Yoon, DJUIDC2013-093 (KH); Bonghwa-gun, 10 May 2008, J. O. Hyun et al., $403024(\mathrm{KH})$.

\section{Pseudostellaria baekdusanensis M. Kim}

KOREA. Gangwon-do: Inje-gun, 29 May 2013, S. H. Oh et al., KH2038, KH1967, KH2107, KH2137 (KH). Hamgyeongbukdo: Baekdusan Mt., 20 May 2014, M. Kim, 20140241-20140244 (JNU); 12 Jun 2014, M. Kim, 20140248 (JNU).

\section{Pseudostellaria davidii (Franch.) Pax}

KOREA. Gyeonggi-do: Gapyeong-gun, 7 May 2010, E. S. Jeon, ESJeon100508 (KH); 16 May 2012, B. U. Oh et al., Gapyeonggun (Myeomggisan)-120516-042 (KH); Pocheon-si, 7 Jul 2007, W. K. Paik, PWK-2012-0187 (KH); Namyangju-si, 31 May 2004, S.S. Kim, Kss0806 (KH). Gangwon-do: Inje-gun, 6 Jun 2018, H. Jo, JI60615, JI60617 (JNU); 1 Jul 2009, S. C. Ko, HNHM-20090031 (KH); 22 May 2008, K. S. Lee et al., GJ-0800084 (KH); Yanggu-gun, 23 May 2008, W. K. Paik, PWK-0267 (KH); Yangyanggun, 13 May 2011, K. O. Yoo et al., K.O.Yoo. 0013 (KH); Taebaek-si, 7 May 2015, H. Jo, JF50717-JF50722 (JNU); 4 Jun 2018, H. Jo, JI60410, JI60413 (JNU); 31 May 2009, J. O. Hyun et al., 301014 (KH); Wonju-si, 7 Jun 2018, H. Jo, JI60725-JI60726 (JNU); 2 Sep 2008, S. C. Ko, s.n. (KH); Hongcheon-gun, 4 May 2010, E. S. Jeon, ESJeon100482 (KH); Whacjeon-gun, 30 May 2008, C. S. Jang, Seokryeomgsan80530-98 (KH); 30 May 2008, J. M. Kim, Bokjusan80530-149 (KH); 29 May 2008, B. H. Ahn, Ilsan80529-76 (KH); 29 May 2008, B. H. Ahn, Ilsan80529-73 (KH); Cheolwon-gun, 21 May 2008, E. S. Jeon \& Y. S. Park, ESJeon80272 (KH); Chuncheon-si, 11 May 2010, Y. M. Lee et al., L100646 (KH); Samcheok-si, 11 Jun 2009, J. C. Yang et al, K10252 (KH); 19 Mar 2009, B. H. Cho et al., 304018 (KH); 5 Apr 2009, J. O. Hyun et al., 203016 (KH); Gangneung-si, 18 Apr 2008, G. Y. Chung, HNHM-2009-0729 (KH); Pyeongchang-gun, 23 May 2008, G. Y. Chung et al., 080523-042 (KH); Jeongseongun, 24 May 2012, H. S. Lee et al, HNHM-2012-0002 (KH); 13 May 2010, Y. M. Lee et al., L100272 (KH); 13 May 2010, Y. M. Lee et al., L100140 (KH); 30 May 2009, J. C. Yang et al, Y90179 (KH); Yeongyeol-gun, 28 Jul 2010, G. S. Kim \& H. J. Lee, Y100930 (KH). Chungcheongbuk-do: Jecheon-si, 6 May 2015, H. Jo, JF50607 (JNU); Danyang-gun, 6 May 2015, H. Jo, JF50608JF50613, JF50623 (JNU); Jincheon-gun, 15 May 1999, C. H. Hyun, 1716 (KH); Chungcheongnam-do: Cheonan-si, 10 May 2009 , S. S. Kim, Kim-6 (KH). Jeollabuk-do: Muju-gun, 22 May 1993, H. I. Yeo et al., 1713 (KH); Guryeo-gun, 4 Jun 2004, B. U. Oh et al., Guryeogun(Jirisan)-040604-054 (KH). Gyeongsangbuk-do: Yeongcheon-si, 17 May 2014, H. Jo, JE51703-JE51705 (JNU); 2 Jul 2017, H. Jo, JH70201, JH70204 (JNU); 1 Jun 2009, S. C. Ko, HNHM-2009-0030 (KH); Yeongyang-gun, 11 Jun 2012 , B. 
U. Oh et al., Yeongyanggun (Ilwolsan)-120611-005 (KH); Bongwha-gun, 8 Jul 2010, Y. C. Cho et al., C100030 (KH); 8 Jul 2010 , Y. C. Cho et al., C100070 (KH); Cheongsong-gun, 8 May 2015, H. Jo, JF50801-JF50803 (JNU); 8 Jun 2018, H. Jo, JI60830 (JNU). Gyeongsangnam-do: Hamyang-gun, 9 May 2018, H. Jo, JI50901 (JNU); Geochang-gun, 19 May 2014, Y. H. Cho \& H. J. Na, WR-140519-066 (KH); Yangsan-si, 14 Apr 2009, J. O. Hyun et al., NAPI-2009-0090 (KH); Milyang-gun, 15 May 2012 , H. S. Lee et al, HNHM-2012-0001 (KH). Daegu-si: 2 Jun 2015, H. Jo, JF60203 (JNU). Hamgyeongbuk-do: Baekdusan Mt., 14 Jun 2012, M. Kim, s.n. (JNU); 20 May 2014, M. Kim, s.n. (JNU); 17 May 2009, D. K. Lee, 2009-0156 (KH).

\section{Pseudostellaria okamotoi Ohwi var. okamotoi}

KOREA. Jeollabuk-do: Muju-gun, 7 May 2015, H. S. Choi, s.n. (6 sheets) (JNU); Namwon-si, 30 Apr 2018, H. Jo, JI43006JI43007 (JNU); 30 May 2018, H. Jo, JI53010-JI53012 (JNU). Jeollanam-do: Gwangyang-si, 16 Apr 2018, H. Jo, JI41603, JI41619 (JNU); 30 May 2018, H. Jo, JI53020-JI53022 (JNU). Gyeongsangbuk-do: Seongju-gun, 16 May 2015, H. Jo, JF51602, JF51603 (JNU). Gyeongsangnam-do: Hamyang-gun, 16 May 2014, H. Jo, JE51617, JE51619, JE51621-JE51622, JE51624, JE51628JE51629, JE51638-JE51639, JE51641, JE51643 (JNU); 23 Jun 2014, H. Jo, JE62320-JE62325 (JNU); 17 May 2015, H. Jo, JF5101-JF5111 (JNU); 9 May 2018, H. Jo, JI50902-JI50908 (JNU); Hadong-gun, 17 May 2018, C. G. Shin, Shin18-051701, Shin18-051702 (JNU); Habcheon-gun, 16 May 2015, H. Jo, JF51600-JF51601 (JNU).

\section{Pseudostellaria okamotoi var. longipedicellata (S. Lee, K. I. Heo \& S. C. Kim) H. Jo f. longipedicellata}

KOREA. Gangwon-do: Taebaek-si, 26 Apr 2014, H. Jo, JE42601 (JNU); 24 May 2015, H. Jo, JF52402-JF52404 (JNU); 4 Jun 2018, H. Jo, JI60405-JI60406 (JNU); Pyeongchang-gun, 4 May 2014, H. Jo, JE50430 (JNU); 7 May 2015, H. Jo, JF50723JF50727 (JNU); Yangyang-gun, 21 Apr 2011, K. O. Yoo et al., K. O. Yoo. 0104 (KH); Wonju-si, 7 Jun 2018, H. Jo, JI60715 (JNU); 8 Apr 2008, S. C. Ko, HNHM-2009-0055 (KH); Yeongweol-gun, 14 May 2010, Y. M. Lee et al., H100210 (KH); Jeongseongun, 5 May 2010, J. O. Hyun et al., K0304026 (KH). Chungcheongbuk-do: Danyang-gun, 6 May 2015, H. Jo, JF50614-JF50617 (JNU); 20 May 2006, J. H. Lee et al., SKK 0015 (KH); Jecheon-si, 4 May 2002, S. H. Park, ParkSH21161 (KH); Jellabuk-do: Muju-gun, 13 May 2014, H. S. Choi, s.n. (JNU). Gyeongsangbuk-do: Mungyeong-si, 20 Apr 2014, H. Jo, JE42001 (JNU); 9 Apr 2015, H. Jo, JF40901-JF40904 (JNU); 6 May 2015, H. Jo, JF50605-JF50606 (JNU); Chilgok-gun, 10 Apr 2015, H. Jo, JF41002JF41007 (JNU); 16 May 2015, H. Jo, JF51610-JF51611 (JNU); 17 Apr 2018, H. Jo, JI41721-JI41725 (JNU); 29 May $2018, ~ H$. Jo, JI52910-JI52911 (JNU); Gunwi-gun, 22 Apr 2015, H. Jo, JF42213-JF42217 (JNU); Yeongcheon-si, 2 Jul 2017, H. Jo, JH70205-JH70207 (JNU); Cheongsong-gun, 17 May 2014, H. Jo, JE51701-JE51702 (JNU); 8 May 2015, H. Jo, JF50813JF50817 (JNU); 2 Jun 2015, H. Jo, JF60201, JF60202 (JNU); 8 Jun 2018, H. Jo, JI60825-JI60827 (JNU); Cheongdo-gun, 25 Apr 2017, H. Jo, JH42512-JH42513 (JNU); Bongwha-gun, 19 Mar 2009, H. G. Lee et al., 201001 (KH). Daegu-si: Dalseonggun, 11 Apr 2015, H. Jo, JF41100-JF41107 (JNU). Gyeongsangnam-do: Hamyang-gun, 9 May 2018, H. Jo, JI50904 (JNU); Milyang-gun, 30 Mar 2009, S. C. Ko, HNHM-2009-0064 (KH).

\section{Pseudostellaria palibiniana (Takeda) Ohwi var. palibiniana f. palibiniana}

KOREA. Gyeonggi-do: Namyangju-si, 29 Apr 2015, H. Jo, JF42901-JF42904 (JNU); Gapyeong-gun, 29 Apr 2015, H. Jo, JF42905-JF42906 (JNU); 6 Jun 2018, H. Jo, JI60620-JI60621 (JNU); Anseong-si, 22 Apr 2007, H. T. Im, 70151 (KH). Gangwondo: Inje-gun, 29 Apr 2015, H. Jo, JF42922-JF42923 (JNU); 6 Jun 2018, H. Jo, JI60605-JI60606 (JNU); Hoengseong-gun, 19 Apr 2014, H. Jo, JE42000 (JNU); 2 Jun 2014, H. Jo, JE60210-JE60222 (JNU); 24 May 2011, J. C. Yang et al., JSJ110073 (KH); Hongcheon-gun, 17 May 2011, Y. C. Kim, KYC0480 (KH); Chuncheon-si, 15 May 2012, J. S. Shim, GW_V2012003 (KH). Jeollabukdo: Namwon-si, 3 Jun 2017, H. Jo, JH60303-JH60304 (JNU); 30 Apr 2018, H. Jo, JI43001-JI43005 (JNU); Jinan-gun, 17 Apr 2013, M. Kim et al., 2013JBV009 (KH); Jeonju-si, 16 Apr 2016, M. Kim et al., 2013JBV008 (KH). Jeollanam-do: Damyang-gun, 11 Apr 2015, H. Jo, JF41112-JF41121 (JNU); Wando-gun, 29 May 2011, J. C. Yang \& C. H. Nam, HS110111 (KH); 9 Apr 2018, H. Jo, JI40901-JI40902 (JNU); Gwangyang-si, 16 Apr 2018, H. Jo, JI41601-JI41602 (JNU); 30 May 2018, H. Jo, JI53015JI53016, JI53025-JI53026 (JNU); Yeongam-gun, 2 May 2003, H. T. Im \& S. Y. Park, Im 175 (KH); Jangseong-gun, 2 Apr 2014, K. S. Jang et al., CNUFR0103 (KH). Gyeongsangnam-do: Geoje-si, 21 Apr 2015, H. Jo, JF42125-JF42126 (JNU). Busan-si: 22 Apr 2015, H. Jo, JF42220-JF42225 (JNU). Jeju-do: 18 Apr 2017, H. Jo, JH41801-JH41806 (JNU); Apr 2017, H. Jo, JH41807JH41812 (JNU); 20 Jul 2017, H. Jo, JH72003-JH72006 (JNU); 28 Aug 2017, H. Jo, JH82805-JH82808 (JNU); 30 Aug 2017, H. Jo, JH83001-JH83004 (JNU). 
Pseudostellaria palibiniana var. gageodoensis M. Kim \& H. Jo

KOREA. Jeollanam-do: Shinan-gun, 5 Apr 2015, H. Jo, JF40510-JF40523 (JNU); 11 Apr 2018, H. Jo, JI41101-JI41117 (JNU); 27 May 2018, H. Jo, JI52702-JI52713 (JNU); 29 Jun 2014, M. Kim, s.n. (5 sheet) (JNU).

\section{Pseudostellaria setulosa Ohwi}

KOREA. Gangwon-do: Inje-gun, 25 May 2015, H. Jo, JF52509-JF52511 (JNU); 30 May 2017, H. Jo, JH53008-JH53009 (JNU); 6 Jun 2018, H. Jo, JI60610-JI60611 (JNU); 14 Apr 1998, Y. M. Lee, KNAH014930 (KH); 29 May 2013, S. H. Oh et al., KH2001 (KH); Yanggu-gun, 24 May 2003, E. S. Jeon, ESJeon30364 (KH); Hongcheon-gun, 1 May 2000, Y. C. Choi \& J. Y. Kim, s.n. (KH); 3 May 2008, J. H. Kim \& C. Y. Yoon, Hongcheongu n(Chimseokbyeong)-080503-116 (KH); Hwacheon-gun, 28 Apr 2004, E. H. Jung \& H. Y. Moon, K0428-038 (KH); Hoengseong-gun, 26 Aug 2008, B. W. Han et al., SKK 0784 (KH); 2 Jun 2014, H. Jo, JE60220-JE60221 (JNU); Yangyang-gun, 26 May 2016, H. Jo, JG52622 (JNU); 5 Jun 2018, H. Jo, JI60505 (JNU); Samcheok-si, 16 May 2011, K. S. Lee et al., s.n. (KH); Taebaek-si, 23 Apr 2005, J. S. Kim, kjs050034 (KH); 19 Apr 2009, J. O. Hyun, NAPI-2011-S0115 (KH); 20 Jun 2006, S. T. Lee, SKK 0030 (KH); 7 May 2015, H. Jo, JF50710-JF50716 (JNU); 4 Jun 2018, H. Jo, JI60401-JI60402 (JNU); Pyeongchang-gun, 24 May 2015, H. Jo, JF52401-JF52410 (JNU); 9 May 2017, H. Jo, JH50907 (JNU); 12 May 2010, Y. M. Lee et al., L100365, L100047 (KH); Jeongseon-gun, 5 May 20105 May 2010, J. O. Hyun et al., K0301012 (KH); 5 May 2010, J. O. Hyun et al., K0302010 (KH); 16 May 2008, S. H. Oh, Duwibong8051651 (KH); Yeongwol-gun, 26 Apr 2008, J. O. Hyun et al., 301017 (KH). Chungcheongbuk-do: Danyang-gun, 25 May 2016, H. Jo, JG52506-JG52508 (JNU). Gyeongsangbuk-do: Bongwha-gun, 19 Mar 2009, J. H. Choi \& Y. S. Oh, 305011 (KH); 12 Oct 2008, J. O. Hyun et al., 1402001 (KH).

\section{Pseudostellaria heterophylla (Miq.) Pax f. heterophylla}

KOREA. Incheon-si: 2 May 2007, B. H. Choi et al., Incheonsi(Baekunsan)-070502-080 (KH); 30 May 2007, B. H. Choi \& J. H. Lee, Incheonsi(Goryeosan)-070530-080 (KH); 20 May 2014, S. H. Park et al., PSH141487 (KH); 28 May 2014, S. H. Park et al., PSH141457 (KH). Gyeonggi-do: Pocheon-si, 9 May 2006, S. H. Park \& G. H. Nam, ParkSH60169 (KH); Gapyeong-gun, 29 Apr 2015, H. Jo, JF42907-JF42909 (JNU); 6 Jun 2018, H. Jo, JI60625-JI60626 (JNU); 18 Apr 2006, E. S. Jeon, ESJeon60118 (KH); Ansan-si, 12 May 2011, S. H. Park et al., ParkSH110509 (KH); Goacheon-si, 22 Apr 2006, E. S. Jeon, EsJeon60153 (KH). Gangwondo: Inje-gun, 29 Apr 2015, H. Jo, JF42920-JF42921 (JNU); Cheolwon-gun, 21 May 2006, K.O. Yoo, HNHM-2009-0752 (KH); Wonju-si, 7 Jun 2018, H. Jo, JI60710 (JNU); Hoengseong-gun, 21 Apr 2008, S. C. Ko, s.n. (KH); Chuncheon-si, 5 May 2008 , J. H. Kim \& C. Y. Yoon, Chuncheonsi (Daeryongsan)-080505-069 (KH); 15 Jun 2011, K. O. Yoo et al., K.O. Yoo. 0001 (KH). Chungcheongbuk-do: Danyang-gun, 9 Apr 2015, H. Jo, JF40905-JF40908 (JNU); Jecheon-si, 8 May 2005, B. U. Oh et al., s.n. (KH); Goesan-gun, 12 May 2008, B. U. Oh, 080512-Bogwangsan-001 (KH); Cheongju-si, 19 Apr 2008, B. U. Oh, 080419-Seondosan001 (KH); Jecheon-si, 12 May 2006, B. U. Oh et al., 20310 (KH). Chungcheongnam-do: Geumsan-gun, 3 May 2015, H. S. Choi, s.n. (JNU); Gongju-si, 26 May 2007, J. I. Jeon, Jeon11300 (KH); Cheonan-si, 25 Apr 2006, G. H. Nam, NGH60015 (KH); Seosansi, 27 Apr 2006, S. H. Park \& H. S. Choi, ParkSH63184 (KH); Gongju-si, 26 Apr 2006, S. H. Park \& H. S. Choi, ParkSH63130 (KH); Dangjin-gun, 12 May 2005, J. H. Kim, K345 (KH); Cheongyang-gun, 7 May 2005, E. S. Jeon, ESJeon 50826 (KH). Daejeonsi: 23 Apr 2005, W. G. Paik, P263 (KH); Jeollabuk-do: Namwon-si, 16 Apr 2015, H. S. Choi, s.n. (3 sheet) (JNU); 24 Apr $2012, H$. S. Choi, s.n. (JNU); Wanju-gun, 23 Apr 2013, H. S. Choi, s.n. (JNU); 6 May 2004, J. K. Kim et al., s.n. (KH). Jeollanam-do: Jindogun, 4 Apr 2015, H. Jo, JF40411-JF40422 (JNU); 27 Apr 2015, H. Jo, JF42701-JF42703 (JNU); Damyang-gun, 11 Apr $2015, H$. Jo, JF41108-JF41111 (JNU); Wando-gun, 9 Apr 2018, H. Jo, JI40906 (JNU); Jangseong-gun, 5 Apr 2014, K. S. Jang et al., CNUFR0118 (KH). Gyeongsangbuk-do: Andong-si, 21 Apr 2006, G. E. Yoo et al., s.n. (KH); Yeongju-si, 8 Jun 2018, H. Jo, JI60810JI60811 (JNU); Mungyeong-si, 6 May 2015, H. Jo, JF50601-JF50604 (JNU); 23 May 2015, H. Jo, JF52301 (JNU); 8 May 2017, H. Jo, JH50801 (JNU); 29 May 2017, H. Jo, JH52901-JH52902 (JNU); 3 Jun 2018, H. Jo, JI60301 (JNU); Chilgok-gun, 10 Apr 2015, H. Jo, JF41008-JF41012 (JNU); 16 May 2015, H. Jo, JF51604-JF51609 (JNU); 25 Apr 2017, H. Jo, JH42501-JH42504 (JNU); 17 Apr 2018, H. Jo, JI41715-JI41720 (JNU); 17 Apr 2018, H. Jo, JI41716-JI41719 (JNU); 29 May 2018, H. Jo, JI52915JI52916 (JNU); Gunwi-gun, 17 Apr 2018, H. Jo, JI41704-JI41706 (JNU); 8 Jun 2018, H. Jo, JI60845-JI60846 (JNU). Gyeongsangnam-do: Tongyeong-si, 21 Apr 2015, H. Jo, JF42110-JF42119 (JNU); Changnyeong-gun, 16 Apr 2018, H. Jo, JI41620JI41625 (JNU); Hapcheon-gun, 30 Apr 1994, H. C. Ahn et al., 01828 (KH). Daegu-si: 23 Apr 2015, H. Jo, JF42304-JF42307 (JNU); 17 Apr 2018, H. Jo, JI41701-JI41703 (JNU); 30 May 2018, H. Jo, JI53001-JI53002 (JNU). 
Pseudostellaria $\times$ bohyeonsanensis M. Kim \& H. Jo

KOREA. Gyeongsangbuk-do: Cheongsong-gun, 8 May 2015, H. Jo, JF50804-JF50812, JF50818-JF50820 (JNU); 22 Jun 2015, H. Jo, JF62203 (JNU); 25 May 2016, H. Jo, JG52502-JG52505 (JNU); 2 Jul 2017, H. Jo, JH70208, JH70211 (JNU).

Pseudostellaria $\times$ biseulsanensis M. Kim \& H. Jo

KOREA. Daegu-si: 23 Apr 2015, H. Jo, JF42301-JF42303 (JNU). Gyeongsangbuk-do: Chilgok-gun, 10 Apr 2015, H. Jo, JF41015 (JNU).

Pseudostellaria $\times$ seoraksanensis $\mathrm{M}$. Kim \& H. Jo

KOREA. Gangwon-do: Inje-gun, 6 Jun 2018, H. Jo, JI60601 (JNU).

Pseudostellaria $\times$ segeolsanensis M. Kim \& H. Jo

KOREA. Jeollabuk-do: Namwon-si, 30 Apr 2018, H. Jo, JI43008, JI43009-JI43012 (JNU); 30 May 2018, H. Jo, JI53005$J I 53008$ (JNU). 